Prepared for The Nature Conservancy Palmyra Program

\title{
Terrestrial Forest Management Plan for Palmyra Atoll
}

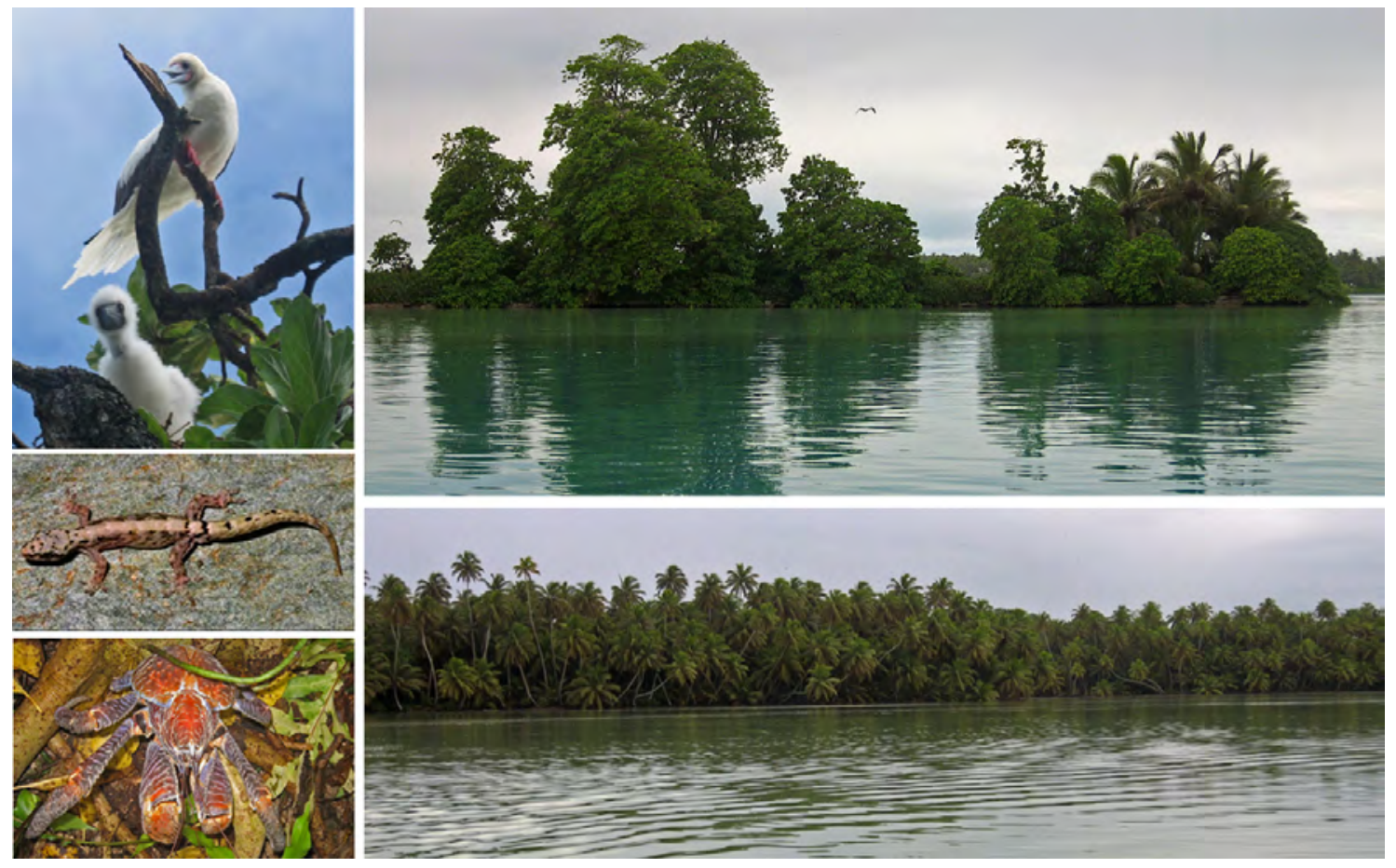

Open-File Report 2011-1007 
Cover: Images showing native species of the terrestrial forest at Palmyra Atoll (on the left from top to bottom: red-footed boobies, an undescribed gecko, and a coconut crab). The forests shown are examples of Pisonia grandis forest on Lost Islet (above) and an example of coconut palm monoculture on Kaula Islet (below) at Palmyra Atoll.

(Photographs by Stacie Hathaway, U.S. Geological Survey, 2008.) 


\section{Terrestrial Forest Management Plan for Palmyra Atoll}

By Stacie A. Hathaway, Kathryn McEachern, and Robert N. Fisher

Prepared for The Nature Conservancy Palmyra Program

Open-File Report 2011-1007 


\section{U.S. Department of the Interior \\ KEN SALAZAR, Secretary}

\section{U.S. Geological Survey \\ Marcia K. McNutt, Director}

U.S. Geological Survey, Reston, Virginia: 2011

For more information on the USGS-the Federal source for science about the Earth, its natural and living resources, natural hazards, and the environment, visit http://www.usgs.gov or call 1-888-ASK-USGS.

For an overview of USGS information products, including maps, imagery, and publications, visit http://www.usgs.gov/pubprod

To order this and other USGS information products, visit http://store.usgs.gov

Suggested citation:

Hathaway, S.A., McEachern, K., and Fisher, R.N., 2011, Terrestrial forest management plan for Palmyra Atoll: U.S. Geological Survey Open-File Report 2011-1007, 78 p.

Any use of trade, product, or firm names is for descriptive purposes only and does not imply endorsement by the U.S. Government.

Although this report is in the public domain, permission must be secured from the individual copyright owners to reproduce any copyrighted material contained within this report. 


\section{Contents}

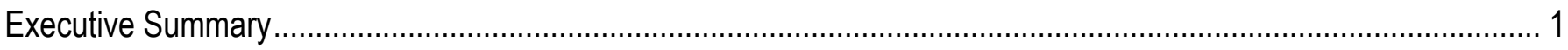

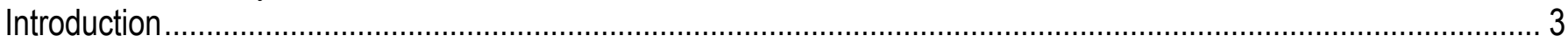

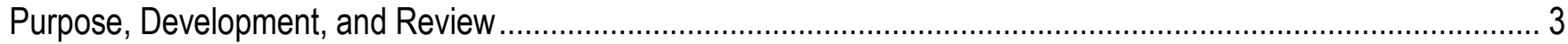

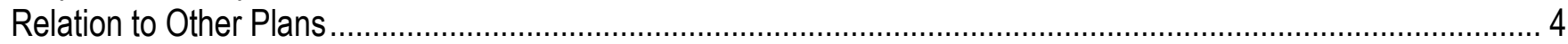

Value of Palmyra Atoll at Multiple Scales..................................................................................................... 4

Mission and Purpose of Palmyra Atoll Under Joint Ownership of TNC and the FWS ........................................... 5

Mission, Goals, and Refuge Purposes of the FWS National Wildlife Refuge System ........................................... 5

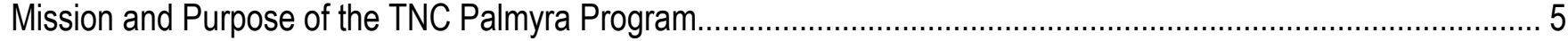

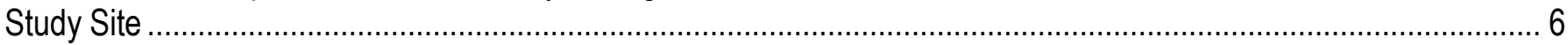

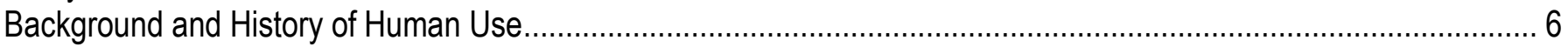

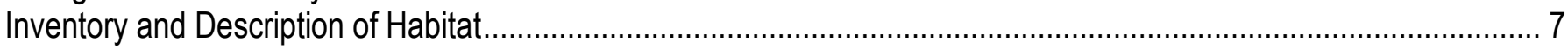

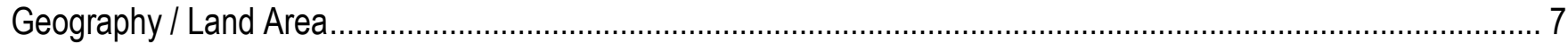

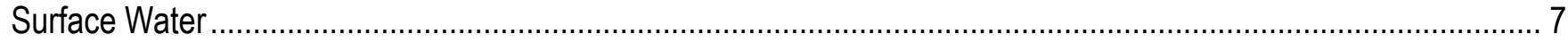

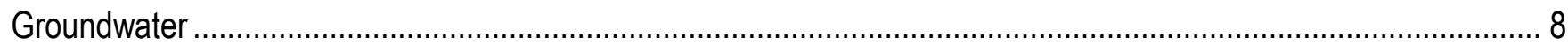

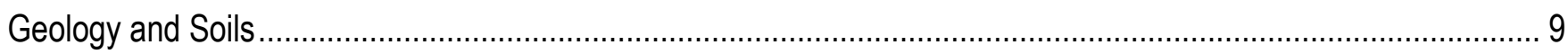

Flora

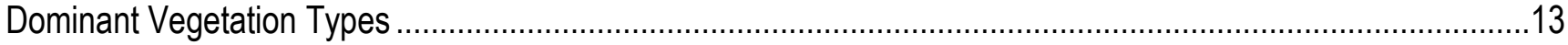

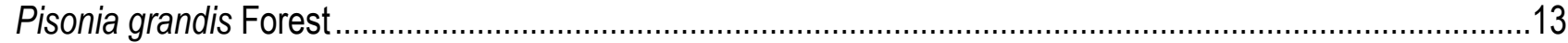

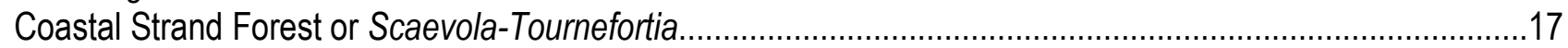

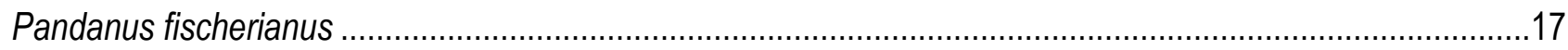

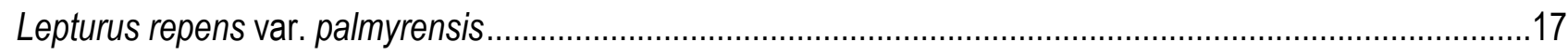

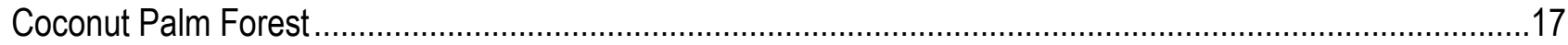

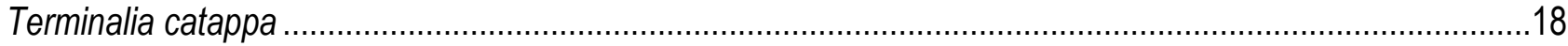

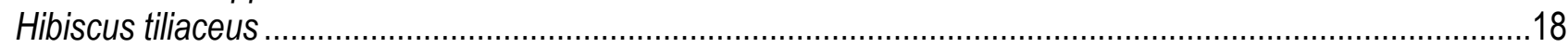

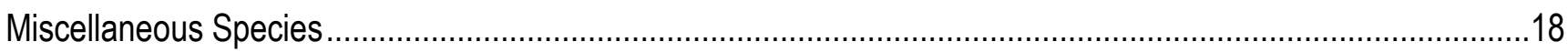

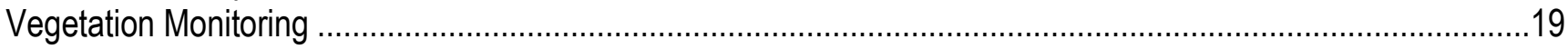

Fauna

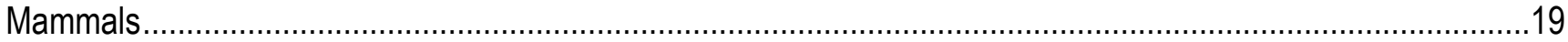

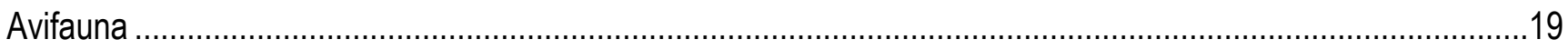

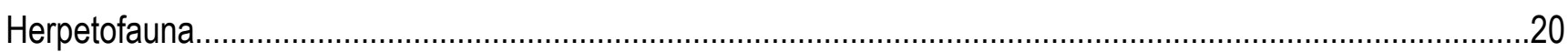

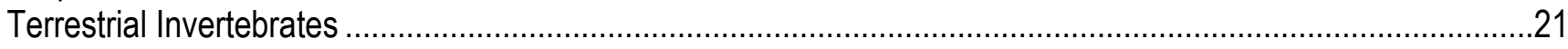

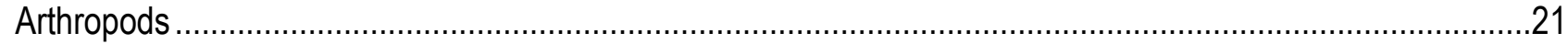

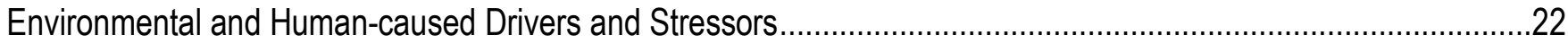

Storms

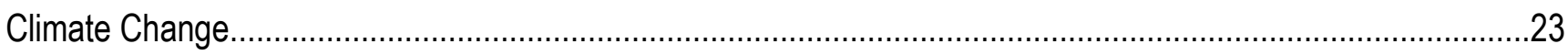

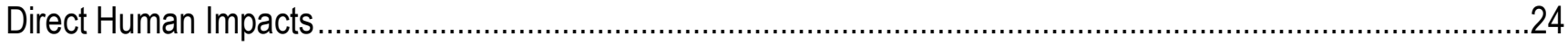

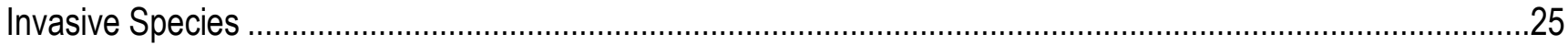

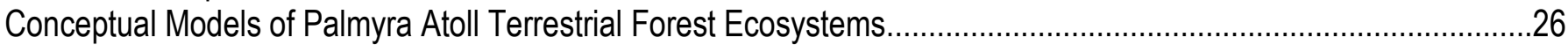

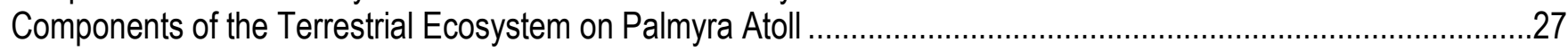

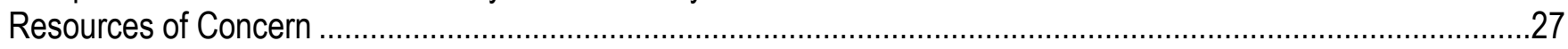

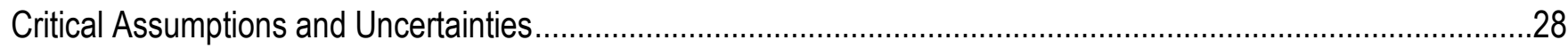

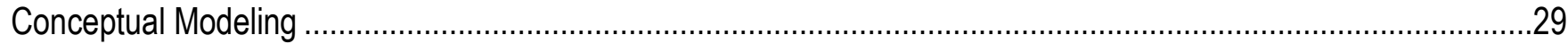

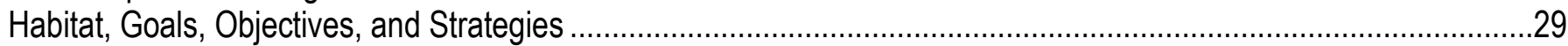

Goals and Objectives of the "Terrestrial Forest Management Plan for Palmyra Atoll" .............................................31

Management Goals, Objectives, and Strategies for the Palmyra Atoll Terrestrial Forest ...........................................32 


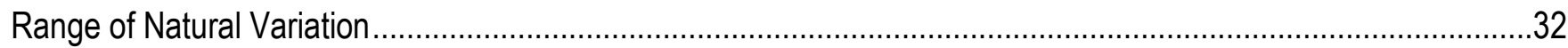

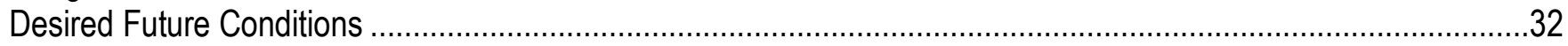

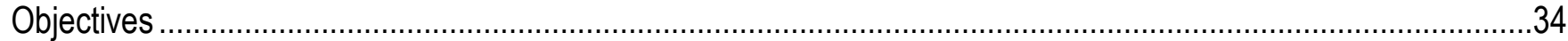

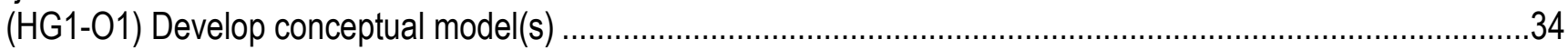

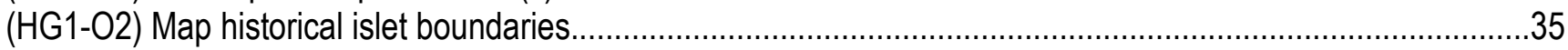

(HG1-03) Measure, classify, and map terrestrial vegetation ………….....................................................36

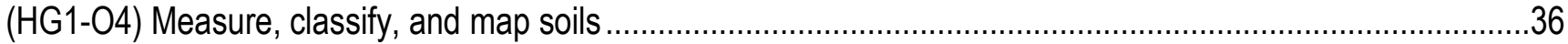

(HG1-05) Measure, classify, and map groundwater ………................................................................37

(HG1-06) Maintain existing Pisonia grandis stands and promote new growth and expansion.............................38

(HG1-07) Control coconut palm succession and incursion into Pisonia grandis stands that have suffered

moderate to extensive mortality during the scale infestation. ........................................................................39

(HG1-08) Create openings for native coastal shrubs to colonize monotypic coconut palm stands......................40

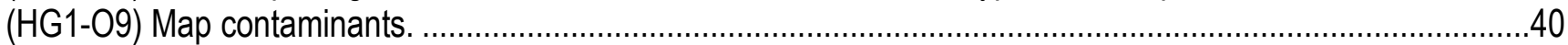

(HG1-010) Remediate contaminants in priority areas.............................................................................

(HG1-011) Evaluate potential short- and long-term impacts of climate change..............................................41

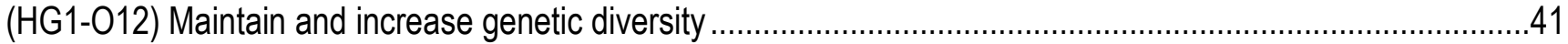

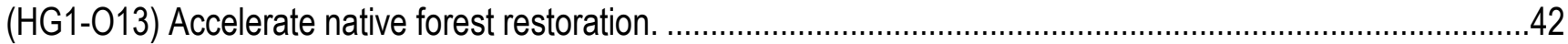

(HG1-014) Reintroduce former native fauna species extirpated from Palmyra Atoll........................................43

Scope and Limitations of this "Terrestrial Forest Management Plan for Palmyra Atoll" .........................................43

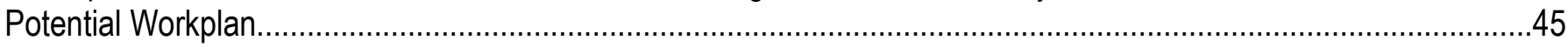

Phase 1

Phase 2

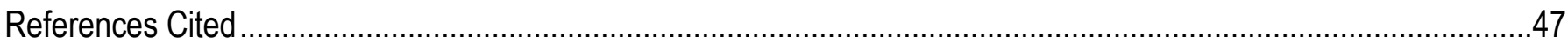

Appendix: Phase 1 Workplan ...................................................................................................................

\section{Tables}

Table 1. Terrestrial plant species that have been identified at Palmyra Atoll.

Table 2. Native terrestrial vascular plant species that have been identified at Palmyra Atoll with qualitative

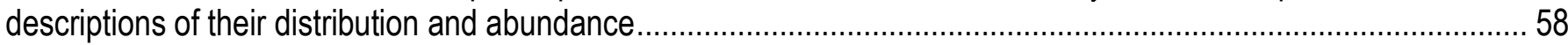

Table 3. Collectors of vascular plants at Palmyra Atoll in chronological order ....................................................... 59

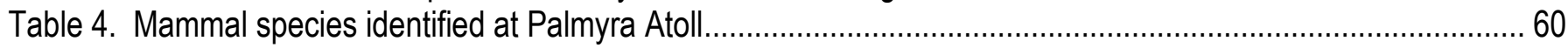

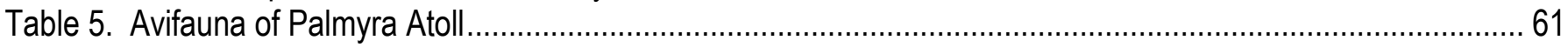

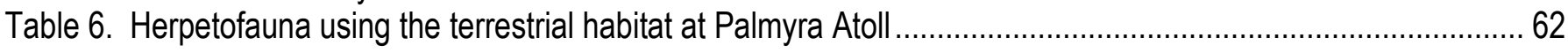

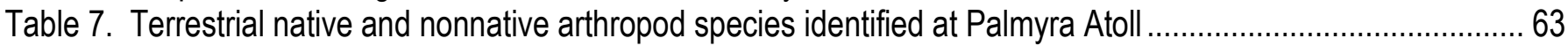

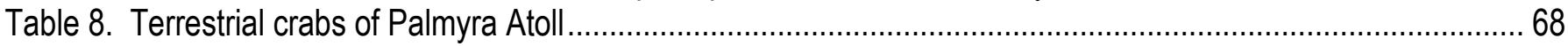

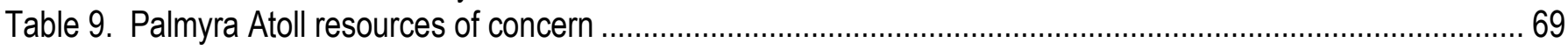

Table 10. Experts consulted regarding Palmyra Atoll management planning......................................................... 71

\section{Figures}

Figure 1. Map of Palmyra Atoll.

Figure 2. State-transition model for restoration of Pisonia grandis forest within Palmyra Atoll ................................... 73

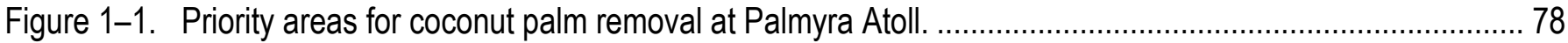




\section{Conversion Factors}

\begin{tabular}{lll}
\hline \multicolumn{1}{c}{ Multiply } & By & \multicolumn{1}{c}{ To obtain } \\
\hline & Length & \\
\hline millimeter $(\mathrm{mm})$ & 0.03937 & inch (in) \\
meter $(\mathrm{m})$ & 3.281 & foot (ft) \\
kilometer $(\mathrm{km})$ & 0.6214 & mile (mi) \\
\hline & Area & \\
\hline square kilometer $\left(\mathrm{km}^{2}\right)$ & 0.3861 & square mile $\left(\mathrm{mi}^{2}\right)$ \\
\hline
\end{tabular}

Temperature in degrees Celsius $\left({ }^{\circ} \mathrm{C}\right)$ may be converted to degrees Fahrenheit $\left({ }^{\circ} \mathrm{F}\right)$ as follows:

${ }^{\circ} \mathrm{F}=\left(1.8 \times{ }^{\circ} \mathrm{C}\right)+32$. 


\title{
Terrestrial Forest Management Plan for Palmyra Atoll
}

\author{
By Stacie A. Hathaway, Kathryn McEachern, and Robert N. Fisher
}

\section{Executive Summary}

This “Terrestrial Forest Management Plan for Palmyra Atoll” was developed by the U.S. Geological Survey (USGS) for The Nature Conservancy (TNC) Palmyra Program to refine and expand goals and objectives developed through the Conservation Action Plan process. It is one in a series of adaptive management plans designed to achieve TNC's mission toward the protection and enhancement of native wildlife and habitat. The "Terrestrial Forest Management Plan for Palmyra Atoll" focuses on ecosystem integrity and specifically identifies and addresses issues related to assessing the status and distribution of resources, as well as the pressures acting upon them, most specifically nonnative and potentially invasive species. The plan, which presents strategies for increasing ecosystem integrity, provides a framework to implement and track the progress of conservation and restoration goals related to terrestrial resources on Palmyra Atoll. The report in its present form is intended to be an overview of what is known about historical and current forest resources; it is not an exhaustive review of all available literature relevant to forest management but an attempt to assemble as much information specific to Palmyra Atoll as possible.

Palmyra Atoll is one of the Northern Line Islands in the Pacific Ocean southwest of the Hawai ian Islands. It consists of many heavily vegetated islets arranged in a horseshoe pattern around four lagoons and surrounded by a coral reef. The terrestrial ecosystem consists of three primary native vegetation types: Pisonia grandis forest, coastal strand forest, and grassland. Among these vegetation types, the health and extent of Pisonia grandis forest is of particular concern. Overall, the three vegetation types support 25 native plant species (two of which may be extirpated), 14 species of sea birds, six shore birds, at least one native reptile, at least seven native insects, and six native land crabs. Green and hawksbill turtles forage at Palmyra Atoll, and though rarely documented, beach nesting could be affected by terrestrial management actions. There are various nonnative or invasive species throughout the terrestrial ecosystem. The most notable examples of terrestrial invasive species include coconut palms (Cocos nucifera) and black rats (Rattus rattus). Although it is unclear whether they are nonnative, coconut palms are currently the most dominant plant across Palmyra Atoll. They compete with native plant species for space and resources and are potentially detrimental to sea birds dependent on native vegetation for roosting and nesting habitat. This competition in turn impacts nutrient resource availability, thereby reshaping energy flow in the ecosystem. Black rats are known to prey on groundnesting sea birds and are likely responsible for the lack of burrowing sea bird reproduction at Palmyra Atoll. In addition, they may be facilitating the invasion of other nonnative species and negatively impacting other native fauna. Although the extent and impacts of these and other nonnative and (or) invasive species are not fully understood, the extent and impacts are clearly a threat to the native species and one of the most urgent threats to the overall ecosystem integrity of Palmyra Atoll. 
This “Terrestrial Forest Management Plan for Palmyra Atoll” addresses issues related to invasive species and other problems. Priority goals are established as are associated objectives and strategies. The overarching goal is to perpetuate and where possible restore terrestrial ecosystem integrity through the following techniques:

1. Habitat management: Maintain and enhance habitat to the extent possible to sustain thriving Pisonia grandis forest, coastal strand forest, endemic grassland, self-sustaining populations of sea birds, shore birds, coconut crabs, native lizards, and native insects.

2. Monitoring and assessment: Acquire information on distribution and abundance as needed for conservation of each resource of concern by developing monitoring and assessment programs relevant to local, regional, and global needs.

3. Research: Gather new information to facilitate conservation of terrestrial forest resources. This information will deal with the ecology of the terrestrial ecosystem.

4. Planning: Achieve regional cooperation for conservation by developing a process to facilitate planning among relevant agencies and by working toward integration of resource concerns with land management plans at local to global levels.

In terms of ecosystem integrity, prevention is the most effective and efficient tool for managing invasive species. There are various potential pathways for introduction and spread of nonnative species within Palmyra Atoll's terrestrial ecosystems, and these concerns have largely been addressed within the "Biosecurity Plan for Palmyra Atoll". Several invasive species have already become established at Palmyra Atoll, however, and control of coconut palms and rat eradication are the major priorities for adaptive forest management action. Other critical steps to minimize the impacts and spread of invasive species include early detection through inventory and monitoring, as well as containment, control, and management of other nonnative species already established at Palmyra Atoll. These efforts in combination with research and education will serve to inform management decisions related to ecosystem integrity.

Along with reinstating ecosystem integrity, this "Terrestrial Forest Management Plan for Palmyra Atoll" aims to evaluate other risk factors that possibly may compromise the persistence of natural resources at Palmyra Atoll. To that end, an adaptive management process of monitoring and plan audit and review is highly recommended to ensure the implementation and efficacy of the management practices outlined above. In addition, it will be important to identify other stressors and threats to the terrestrial ecosystem to prioritize additional management actions. It is essential to develop partnerships with relevant agencies and participate in collaborative efforts to evaluate the best management practices for protecting and conserving these resources into the future, as well as to forecast and avoid potential problems over the long term.

We advise ongoing assessment of this "Terrestrial Forest Management Plan for Palmyra Atoll", as it contains strategies that require widespread cooperation and coordination to be effective. The "Terrestrial Forest Management Plan for Palmyra Atoll" is a working document and subject to periodic review, refinement, and improvement as new information becomes available. The strategies associated with incipient and established nonnative species will continue to be developed and should be implemented in an adaptive management framework. Constant review and evaluation of these management procedures will provide important management information to improve protocols and methods. Refining conservation goals via feedback loops can improve the ability of TNC and their partners to make effective decisions in evaluating and conserving ecosystem integrity. 


\section{Introduction}

This "Terrestrial Forest Management Plan for Palmyra Atoll” has been designed to assist The Nature Conservancy (TNC) in carrying out their Palmyra Atoll Program mission and achieving the Palmyra Atoll Program objectives. On the basis of assessments of the biological uniqueness and importance of Palmyra Atoll, TNC purchased the atoll in 2000 to preserve the biological diversity of Palmyra. TNC now shares ownership of Palmyra Atoll with the U.S. Fish and Wildlife Service (FWS). In 2001, Secretary of the Interior Bruce Babbitt signed Secretary Order No. 3224, creating a submerged lands refuge, which included about 22 square kilometers $\left(\mathrm{km}^{2}\right)$ of waters beyond the emergent land of Palmyra Atoll (Department of the Interior, 2001). This order was followed by the purchase of about 1.7

$\mathrm{km}^{2}$ and about $1 \mathrm{~km}^{2}$ of emergent land from TNC by the FWS in 2001 and 2006, respectively. Together, these parcels represent the current extent of the Palmyra Atoll National Wildlife Refuge. This joint ownership results in TNC working in collaboration with the FWS toward identifying and achieving consistent and compatible goals and objectives for Palmyra Atoll ecosystems. A working partnership between TNC and the FWS is very important, as an ecosystem approach to management requires partner collaboration and coordination for adaptive management at an ecosystem level to be successful.

\section{Purpose, Development, and Review}

This "Terrestrial Forest Management Plan for Palmyra Atoll” is intended to continue efforts begun by TNC and the FWS to develop effective and efficient management planning for Palmyra Atoll. It presents the foundation for an adaptive management approach to the conservation and recovery of native Palmyra Atoll terrestrial ecosystems, as well as priority management needs under consideration for inclusion in a comprehensive conservation plan for the Palmyra Atoll National Wildlife Refuge. As part of an adaptive management process, this plan will help move TNC toward a final, yet dynamic, working document. It was developed in consultation with the FWS, TNC, U.S. Geological Survey (USGS), and academic scientists. This plan is based on current understanding of Palmyra Atoll's ecosystem component composition, structure, and function from management documents, research results, and expert knowledge.

Management plans are composed to include specific strategies to address management goals and objectives. Each goal is intended to result in a desired future condition, a specific need for action, and objectives and associated strategies designed to achieve that action. Objectives and strategies are designed for implementation of management targets, restoration of conservation targets, threatened and endangered species recovery, regulations, research and educational partnerships, habitat preservation, and appropriate public uses over a multiyear period.

Elements of ecosystem management include sustainability, establishing goals, a sound basis in ecological models and understanding, recognizing the importance of biodiversity and structural complexity and the interconnectedness and dynamic character of ecosystems, the consideration of the range of spatial and temporal scales, the role of humans as necessary for achieving sustainable ecosystem management goals, and the importance of adaptability and accountability (Christensen and others, 1996). This approach requires managers to have access to extensive information and data about the system, including historical and baseline conditions, the interactions among the components of the ecosystem, and the consequences of natural and human-caused impacts.

Ecosystem management programs are developed with the knowledge that there are many uncertainties about the behavior of the complex and ever-changing ecological systems these plans are intended to conserve and manage (Christensen and others, 1996). It is unclear how ecosystems will 
respond to disturbances such as storms or management actions, some of which are spatially extensive, more intense, or more frequent than the natural range of disturbance. Uncertainties exist because of lack of ecological information, including knowledge about species life histories, upon which models of ecological functioning can be built. Sampling bias, analytical error, and questionable quality of data can all contribute to uncertainty about the conservation strategy and management decisions (Atkinson and others, 2004).

Because management plans are faced inherently with limited knowledge and limited ability to make predictions, they should be designed to improve the understanding of the ecological systems that managers are attempting to conserve and restore. This design allows for evaluating management strategies as appropriate in an adaptive management framework. The strategies should include robust monitoring programs to track progress toward management objectives and should maximize ability to meet those objectives in a scientifically defensible and cost effective way while minimizing the risks to the ecosystem.

Inherent in the adaptive management approach is the assumption that as new information becomes available through management effectiveness monitoring and new research, management strategies will be adapted or altered to better meet the planned goals. Therefore, this plan should remain flexible, and implementation of approved actions should begin as resources become available. The evolving document will be used to continue developing the goals, objectives, and strategies necessary for achieving desired outcomes; plan implementation; a monitoring and evaluation framework; and integration of ecosystem science, scientific research, information management, and education and outreach.

This document should be reviewed annually and constitutes an essential aspect of adaptive management, critical for identifying problems and modifying actions as necessary. It should be revisited at least once every 5 years with an intensive review and should be updated on the basis of new information from monitoring and relevant research.

\section{Relation to Other Plans}

This document is accompanied by the "Biosecurity Plan for Palmyra Atoll" (Hathaway and Fisher, 2010) and the "Draft Initial Monitoring Plan" (Lafferty and Kushner, 2008). Together, the three documents provide a starting point for the management and monitoring activities necessary to carry out the TNC Palmyra Program Mission. The three documents have been drafted as separate pieces, but there are strong links between the terrestrial and marine ecosystems. They should ultimately be considered together for compatible and comprehensive management. These plans have been developed in accordance with information provided in other relevant plans, including the "Regional Seabird Conservation Plan" (U.S. Fish and Wildlife Service, 2005), "Pacific Islands Regional Shorebird Conservation Plan" (Engilis and Naughton, 2004), "Birds of Conservation Concern" (U.S. Fish and Wildlife Service, 2002), and "Waterbird Conservation for the Americas: The North American Waterbird Conservation Plan" (Kushlan and others, 2002).

\section{Value of Palmyra Atoll at Multiple Scales}

This document presents a strategy for maintaining and restoring the terrestrial components of Palmyra Atoll National Wildlife Refuge while acknowledging that it is part of the larger integrated terrestrial-marine ecosystem. The conservation and restoration of Palmyra Atoll resources contribute to a reduction in the current rate of loss of biological diversity locally, regionally, nationally, and globally. Palmyra Atoll is one of few remote, uninhabited, and protected terrestrial and marine ecosystems in the world. It is a great resource not only in and of itself but also as a natural management and monitoring 
laboratory for research on short-term and long-term responses to local, regional, and global environmental and human-caused stressors. Palmyra Atoll provides a place for development of management techniques that can be applied directly onsite and elsewhere.

\section{Mission and Purpose of Palmyra Atoll Under Joint Ownership of TNC and the FWS}

\section{Mission, Goals, and Refuge Purposes of the FWS National Wildlife Refuge System}

The mission of the FWS National Wildlife Refuge System is “...to administer a national network of lands and waters for the conservation, management, and where appropriate, restoration of the fish, wildlife, and plant resources and their habitats within the United States for the benefit of present and future generations of Americans" (U.S. Fish and Wildlife Service, 2006). The purpose for which a refuge was established or acquired is of key importance to refuge planning and refuge purpose(s), and the refuge system's mission forms the foundation for management decisions. The purposes of a refuge are specified or derived from the law, proclamation, executive order, agreement, public land order, donation document, or administrative memorandum that establishes, authorizes, or expands a refuge. The purpose of Palmyra Atoll National Wildlife Refuge, as stated in the Secretary's Order, is “*** to protect and preserve the natural character of fish, wildlife, plants, coral reef communities and other resources associated with the tidal lands, submerged lands, and waters of Palmyra."

Maintaining ecological integrity is often cited as the primary goal of ecosystem-based management, including the National Wildlife Refuge System Administration Act of 1966 as amended by the National Wildlife Refuge System Improvement Act of 1997, 16 U.S.C. 668dd-668ee (Refuge Administration Act) Section 4(a)(4)(B). One of the 14 directives of this law states that "In administering the System, the Secretary shall $* * *$ ensure that the biological integrity, diversity, and environmental health of the System are maintained for the benefit of present and future generations of Americans ***." In addition, the Refuge Administration Act, as amended, clearly establishes that wildlife conservation is the singular National Wildlife Refuge System mission. House Report 105-106 accompanying the National Wildlife Refuge System Improvement Act of 1997 states “**** the fundamental mission of our System is wildlife conservation: wildlife and wildlife conservation must come first."

As stated in FWS $601 \mathrm{FW} \mathrm{3,} \mathrm{it} \mathrm{is} \mathrm{the} \mathrm{intent} \mathrm{of} \mathrm{the} \mathrm{FWS} \mathrm{to,} \mathrm{first} \mathrm{and} \mathrm{foremost,} \mathrm{maintain} \mathrm{existing}$ levels of biological integrity, diversity, and environmental health at the refuge scale (U.S. Fish and Wildlife Service, 2001). The FWS guidelines call for secondarily restoring lost or severely degraded elements of integrity, diversity, and environmental health at the refuge scale and other appropriate landscape scales where it is feasible and supports achievement of refuge purpose(s) and system mission. (Refer to $601 \mathrm{FW} \mathrm{3,} \mathrm{available} \mathrm{at} \mathrm{http://www.fws.gov/policy/601fw3.html} \mathrm{[accessed} \mathrm{September} \mathrm{1,} \mathrm{2009],}$ for further explanation and definition of terms.)

\section{Mission and Purpose of the TNC Palmyra Program}

The mission and purpose of Palmyra Atoll National Wildlife Refuge, as stated by the FWS, are in line with the TNC Palmyra Program mission "To preserve, protect and restore Palmyra's unique ecosystem while facilitating valuable and responsible research through collaborative partnerships" (as posted at the Palmyra Atoll field station) and the TNC Palmyra Program management priorities, which include "protection and enhancement of wildlife habitat" 
(http://www.nature.org/wherewework/asiapacific/palmyra/about/, accessed September 1, 2009). To date (2010), management programs on Palmyra Atoll have been primarily focused on invasive species management, conservation of the Pisonia grandis forest, restoring altered lagoon hydrology, protecting sea bird nesting colonies, and providing opportunities for the public to learn about wildlife resources through wildlife viewing, interpretation, and recreation (U.S. Fish and Wildlife Service, 2007).

\section{Study Site}

Palmyra Atoll is at about $6^{\circ} \mathrm{N},-162^{\circ} \mathrm{W}$, about $1,600 \mathrm{~km}$ southwest of Honolulu (fig. 1). Palmyra Atoll is at the northern end of the Line Islands in proximity to the Intertropical Convergence Zone. The climate is characterized by high humidity ( $>90$ percent) and warm temperatures (24-27 degrees Celsius $\left.\left[{ }^{\circ} \mathrm{C}\right]\right)$. Palmyra Atoll is considered a wet atoll, receiving nearly 4,500 millimeters $(\mathrm{mm})$ of rain per year (Sadler, 1959). References vary regarding the current number and size of islets, most of which are heavily vegetated; however, a land area of about 250 hectares (ha) was most recently estimated (Collen and others, 2009). The islets do not exceed 2 meters $(\mathrm{m})$ in elevation and reportedly vary in size from about 0.1 to 97.9 ha. They are arranged in a horseshoe pattern around four lagoons surrounded by coral reef. The terrestrial ecosystem supports what have been considered some of the best remaining protected Pisonia grandis forest and large colonies of sea birds, including the second largest colony of red-footed boobies (Sula sula) in the world, as well as significant numbers of migratory shore birds.

\section{Background and History of Human Use}

Palmyra Atoll likely was explored by Micronesians and Polynesians but was never inhabited. The first sighting of the atoll by an American sea captain, Edmond Fanning, was in 1798; however, the atoll was officially discovered and named in 1802 by Captain Sawle of the ship Palmyra. In 1859, Dr. G.P. Judd of the American brig Josephine claimed possession of the atoll for the United States and American Guano Co. In 1898 under the leadership of President McKinley, Palmyra Atoll was acquired by the United States through a Joint Resolution of the $55^{\text {th }}$ Congress, which annexed the territory of Hawai 'i, including Palmyra. In 1911, Judge Henry E. Cooper of Honolulu bought Palmyra Atoll and later sold it to the Fullard-Leo family. There was a short period of military use from 1940 to 1945, during which the atoll and lagoon were modified greatly. In 1947, the Fullard-Leo family reclaimed ownership by U.S. Supreme Court decision. In 1959, Hawai i became the $50^{\text {th }}$ State, but Palmyra Atoll was specifically excluded making it a privately owned U.S. Territory. There were attempts to identify a lucrative guano business and multiple attempts to plant coconut palms (Cocos nucifera) for copra, the dried meat of the coconut that is processed into coconut oil and copra meal (used as livestock feed); however, these ventures were unsuccessful. After the military left, use of the atoll gradually reduced in intensity with only a few known long-term stewards and occasional visits by recreational vessels. Infrastructure left by the military has continued to be used over time (for example, airstrip, dock, some of the roads), has been modified over time for use (for example, water catchment system), or has been essentially abandoned (for example, hospital building, bunkers, pillboxes). In 1987, the Department of the Army, U.S. Army Corps of Engineers, Pacific Ocean Division conducted a Defense Environmental Restoration Program inventory survey of Palmyra Atoll, which was identified and designated on January 2, 1992, as a Formerly Used Defense Site (FUDS) (R.M. Towill Corporation, 1993; Woodward, 2001). Investigation, planning, and remediation activities to locate, evaluate, and remove debris and contaminated materials occurred through 1998 (Environmental Chemical Corporation, 1998).

In August 2000, TNC purchased emergent lands, and on January 18, 2001, by Secretarial Order No. 3224, Palmyra Atoll was established as an FWS national wildlife refuge. The refuge now includes 
all emergent land (with the exception of Cooper and Menge Islets, retained by TNC) and the oceanic area about $22 \mathrm{~km}^{2}$ beyond; however, there are nine areas of tidal and submerged lands containing munitions, vessels, or other materials excluded from this transfer totaling about $491.5 \mathrm{~km}^{2}$ that remain under the jurisdiction of the Deputy Assistant Secretary of Insular Affairs (Department of Interior Office of Insular Affairs, 2006). Palmyra Atoll, one of a few atolls without a long settlement or fishing history, is now managed for conservation and recovery of native habitats. It represents an important land type as one of two U.S. protected atolls currently supporting a sizable Pisonia grandis forest. Rose Atoll, in the Samoan archipelago, is the second atoll with Pisonia grandis forest; however, Rose Atoll is considerably drier and supports a smaller Pisonia grandis forest with less structural complexity, these differences make both atolls important for natural resource conservation.

\section{Inventory and Description of Habitat}

Palmyra Atoll is included in an ecoregion characterized by atolls with open or closed lagoons or raised reef platforms with an elevation of less than $4 \mathrm{~m}$ (Mueller-Dombois and Fosberg, 1998). Despite low endemism and biodiversity in general, these islands protect various natural resources. For example, they support some of the largest populations of sea birds in the world and provide wintering and stopover habitat for migratory shore birds. The majority of these islands have undergone heavy disturbance from activities such as military use, phosphate mining, attempts to establish copra plantations, and invasive species introductions.

In general, the historical habitat conditions of Palmyra Atoll are not extensively known. Dawson (1959) provided a good summary of the known history of Palmyra Atoll and attempted to describe the changes that have taken place on the basis of his observations in comparison to the literature available at the time. For example, there are records of plant collections and descriptions of the vascular flora of Palmyra Atoll dating as far back as 1873. Dr. Thomas Streets described Palmyra Atoll's emergent land as "thickly clothed with vegetation." He also described sooty terns (Onychoprion fuliginosa) breeding at the extreme eastern point of the island in numbers so large that they formed a cloud when driven from the ground, and "their clamor deadens the roar of the surf" (Streets, 1877). Rock $(1916,1929)$ provided similar details on another expedition to the atoll.

\section{Geography / Land Area}

Collen and others (2009) investigated historical maps, navigational charts, and photographs, as well as anecdotal evidence, from 1874 to 2007 and showed that Palmyra Atoll islets originally underwent minor natural changes in shape and size. They also documented modifications to Palmyra Atoll from military construction, including lagoon dredging, the creation of islets, and increased terrestrial connectivity. With these modifications most of the islets of the atoll were enlarged and connected above sea level, resulting in the doubling of land area and almost tripling of land volume. While there has been significant alteration to the geography of the atoll by military occupation, natural processes have already begun breaking down these changes, and lagoon circulation is beginning to be reestablished.

\section{Surface Water}

Christophersen (1927) mentioned freshwater on Holei Islet at a depth of $28 \mathrm{~cm}$ below the surface of a muddy depression. He suggested that this may have been the same depression found by Rock (1916, p. 22) searching for the location of a freshwater pond as indicated on charts. He went on to suggest that a freshwater pond would be intermittent, rising above surface in only wet seasons. In both 
accounts of freshwater on Holei Islet, the surrounding vegetation is described as coconut palms, ferns, and Pandanus. Currently (2010), there are patches of hau (Hibiscus tiliaceus) on Pelican Islet and on the southern end of Home Islet, which also appear to hold surface water intermittently (S. Hathaway, K. McEachern, and R. Fisher, U.S. Geological Survey, oral commun., 2008). There are two other areas, one on Cooper Islet and one on Paradise Islet, which support surface water. On Cooper Islet, the area has been described as an artificial freshwater pond, formerly a cesspool built during military use and recently found to support a stock of freshwater eels (Handler and James, 2006). No other information regarding the origin or status of these freshwater sites was found.

\section{Groundwater}

Little is known about the groundwater at Palmyra Atoll or the role that it is playing in ecosystem

function. Freshwater recharge at coral atolls occurs when infiltrating rainwater displaces the underlying saltwater from the surrounding ocean to form a lens of fresh groundwater. Freshwater lenses in atoll settings are thin vertically relative to their areal extent (Tribble, 2008).

It is unknown whether any groundwater lenses are present at Palmyra Atoll (Suchanek and others, U.S. Geological Survey, written commun., 2007; J. Kulongoski, U.S. Geological Survey, oral commun., 2008). It is also unclear to what extent the native flora and fauna might be dependent upon them or whether they are affected by nonnative species. The size and depth of freshwater lenses are directly related to the size of the islet. While there does not appear to be any clear delineation of minimum size (as reviewed in Lee, 1984), Underwood and others (1992) modeled recharge rates of freshwater lenses and found that, under the assumption that a minimum threshold thickness of $2-3 \mathrm{~m}$ is required to maintain a developable lens, $250 \mathrm{~m}$ (the smallest width tested) would be the minimum island width necessary to support freshwater lens dynamics. More recently Bailey and others (2009) used the most inclusive conceptual model available (Ayers and Vacher, 1986) to model atoll freshwater lens response to climatic factors and geologic variables. They used widths as low as $150 \mathrm{~m}$ in simulations, and results indicated there would likely be a temporary loss of the freshwater lens during the drought effects of El Niño at the lower width atolls. Because of the relatively small islets composing Palmyra Atoll, these studies would indicate there were probably few, if any, freshwater lenses present historically. In contrast, dimensions of $60 \mathrm{~m}$ were reported as suitable for freshwater lens development at Herald Cays (G.N. Batianoff, G.C. Naylor, and H.A. Dillewaard, Queensland Herbarium, written commun., 2007 in Greenslade, 2008). Over time, Palmyra Atoll may provide data on these lower limits tested by Bailey and others (2009) and Underwood and others (1992).

In addition, investigating the presence of freshwater lenses at Palmyra Atoll may be especially worthwhile given current interest in developing artificial islands through lagoon dredging and creating water reserves for other Pacific Islands (Falkland, 2002, in White and others, 2007). White and others (2007) pointed out negative environmental impacts as a result of dredging. The existing augmented land area at Palmyra Atoll may be worth examining for freshwater lenses as an initial feasibility investigation. Likewise, Palmyra Atoll serves as an example for some of the negative environmental impacts that can result from dredging, though there are completely humanmade islets where Nonner and Woodward (2006) found Pisonia grandis forest to be healthier than on other naturally formed islets. They suggest that this phenomenon may be due to slightly higher elevation, which makes the Pisonia grandis forest less susceptible to tidal fluctuation and storm events capable of increasing saltwater intrusion of the water table.

Groundwater is most likely to be more widely present at Palmyra Atoll as a saturated zone. During contaminants investigations at Palmyra, it was reported that the subsurface water table was generally $0.6-1.2 \mathrm{~m}$ below the ground surface and tidally influenced (Environmental Chemical 
Corporation, 1998). To provide insight into plant use of any existing groundwater, Nonner and Woodward (2006) suggested methods examined by O'Grady and others (2006) in which isotopic analyses of both oxygen and hydrogen in potential water sources could be compared with analyses of xylem water in relevant plants to reveal the source of uptake. While it is known that Pisonia grandis has a shallow root system (Walker, 1991), it is unknown whether the trees are largely dependent on rainfall and near surface moisture or whether they rely on reaching groundwater especially during drier periods. If the latter were the case it would be important to determine if groundwater levels are being lowered because of heavy consumption by coconut palms, a species also known to have a rather shallow root system. Walker (1991) suggested that Pisonia grandis has a shallow root system adapted to using near surface water and avoiding contact with the water table.

Use of groundwater by terrestrial fauna, such as burrowing crabs (which are dependent on moisture for their physiology), is unknown for Palmyra Atoll. Gross (1964) indicated that coconut crabs (Birgus latro) and land hermit crabs (Coenobita sp.) can control blood concentration by selecting water of appropriate salinity, but given a choice coconut crabs prefer freshwater and the strawberry hermit crabs (Coenobita perlatus) prefer seawater. Wood and Boutilier (1985) found freshwater in the burrows of the orange land crab (Cardisoma carnifex) but noted that they also readily entered seawater. If native biota do use and require the presence of freshwater as lenses or groundwater, it will be important to assess their vulnerability to saltwater intrusion.

In addition to the uncertainty of groundwater sources, such as whether freshwater lenses exist on Palmyra Atoll, it is not clear if water sources have been compromised by contaminants (J. Kulongoski, U.S. Geological Survey, oral commun., 2008). Only some water sources were tested for remediation during FUDS investigations. For areas subject to remediation, groundwater samples were taken at the water table. Of the measurable contaminants found so far, the levels were considered low enough for safe human use of the area but were not tested for potentially negative effects to biota (Environmental Chemical Corporation, 1998; Wil Chee Planning Inc. and SCS Engineers, 1998). Contaminant assessments of the hospital dump site found various contaminants in the groundwater, but the levels did not exceed U.S. Environmental Protection Agency Maximum Contaminant Levels for drinking water. The assessments considered that because terrestrial and marine organisms use the dump sites this indicated that ecological risk was minimal. None of the measurable contaminants found so far have been identified as phytotoxic (L. Woodward, U.S. Fish and Wildlife Service, written commun., 2009). More recent surveys have begun, and preliminary results are pending (Suchanek and others, U.S. Geological Survey, written commun., 2007; D. Papoulias, U.S. Geological Survey, oral commun., 2008). It is unclear whether the nuclear testing conducted by Great Britain and the United States in the 1950s and 1960s at nearby Malden and Christmas Islands might have resulted in radioactive contamination at Palmyra Atoll because of fallout (Aronson and Anderson, 2000; Woodward, 2001). The FWS considered the need for testing for radioactive materials and determined it was not a major issue of concern at the time of their assessment (Woodward, 2001). It is unknown whether any contaminants have persisted in groundwater or if they are having negative effects on native plant and animal species.

\section{Geology and Soils}

Palmyra Atoll is part of the Line Islands seamount chain and is one of only twelve of these seamounts rising from a sea floor that extends above sea level (Keating, 1992). There are few references to the soil of Palmyra Atoll. Rock (1916) mentions the lack of soil or humus on Home Islet and describes its composition as loose coral fragments, sand, and guano phosphate. Regarding Holei Islet, he describes huge solid blocks of phosphate rock and a 5-cm layer of black humus. These 
accounts are consistent with descriptions of other atolls supporting both Pisonia grandis forest and large numbers of sea birds. In fact, a phenomenon was described by Fosberg $(1954,1957,1994)$ in which Pisonia grandis humus with a $\mathrm{pH}$ of 6.0-4.0 accumulated and combined with bird guano and rainwater to create a phosphate hardpan.

We found only one other reference to the soils of Palmyra Atoll for the time period before military activity. Christophersen (1927) described soils on some of the islets, including Home Islet, Holei Islet, Papala Islet, and Islet A (possibly now referred to as Fern) and Islet B (which appears to be north of Engineer Islet or Tanager Islet), in relation to the vegetation. He reported on the soils of Holei Islet with beach crests having light grayish brown coral sand, similar to Home Islet and supporting tree heliotrope (Tournefortia argentea). He described the interior of Holei Islet as supporting a forest of Pisonia grandis and Neisosperma oppositofolia, with no or very shallow soil composed of a brown to black mold with high water content and acidic $\mathrm{pH}$. Where soil was absent on Holei Islet, Christophersen (1927) describes a coral hardpan almost completely transformed to calcium phosphate and about 10-20 cm thick under which he found yellowish white coral sand. In the eastern part of Holei Islet, forested with coconut palms and Pandanus, he reported soil composed of dark gray sand, alkaline and moist (but drier than soil associated with Pisonia grandis), and a low percentage of organic matter and no hardpan in any place. Islet A was covered by a dense growth of coconut palms with a Phymatosorus scolopendria understory and only a few tree heliotrope. Christophersen (1927) described two types of soil on Islet A with the majority being brown to black moldy sand dispersed in gravel, alkaline with moderate water content, and high in organic content for a sandy soil. Other parts of the islet had a peaty, strongly acidic soil layer with high water content covering the sand. No hardpan was present. Islet B, also dominated by coconut palms but with a bird's nest fern (Asplenium nidus) understory and few tree heliotrope, had soil described as brown, moldy sand in gravel, moist, and alkaline. Again, no hardpan was present. At that time, Papala Islet supported a pure stand of Pisonia grandis with the exception of a single coconut palm. As such, soil conditions on Papala Islet were very different from those Christophersen (1927) described as supporting coconut palms. The soil was shallow dark brown to peaty mold, strongly acidic, moist, and almost entirely composed of organic matter underlain by a hardpan of coral conglomerate almost completely transformed into calcium phosphate.

Much of the current substrate of Palmyra Atoll has been altered since then through military modifications. There was extensive dredging in the lagoon to create a channel and remove obstructions. The resulting dredge materials were distributed throughout the atoll to connect most of the islets via causeways. In addition, the North and South Fighter Strips were created and connected by causeways, and the isolated islets of Sand, Leslie, Dudley, and Ainsley (and four islets around the dredged channel that are no longer present) were created from these dredge materials (Dawson, 1959). Keating (1992) cited the Great Britain Naval Intelligence Division Geographical Handbook Series (1943) describing the soils as variable across islets with beach crests characterized by grayish brown sand, low organic material, and high water content and most interior soils as brown with high organic material and moisture content or as thin soil overlying hard coral ground, reportedly calcium phosphate, underlain by yellow sand. We have been unable, however, to procure the geographic handbook, and it is unknown whether these assessments were made before or after military modification.

Current investigations of soil have also been limited, and comparisons to the past assessments have not been made. Wil Chee Planning Inc. and SCS Engineers (1998) reported a soil investigation at Quail Islet that resulted in a shorefront sequence and inland sequence. The shorefront sequence consisted of 15-30 cm of light-brown, compact, limey sand with coral fragments overlying about a meter of white coral marl with a basement of poorly consolidated detrital limestone. The inland 
sequence was associated with heavy vegetation and consisted of 8-30 cm of very soft, dark brown to gray limey silts, and silty sands over $30-60 \mathrm{~cm}$ of dark gray coral marl with a white limey coral basement. They found that surface debris and recognizable fill materials were generally not found in soil horizons greater than $60 \mathrm{~cm}$ below ground surface. Aronson and Anderson (2000) reported on soils from Cooper Islet and found a top layer of about $10 \mathrm{~cm}$ of dark gray to very dark gray, brown, silty sand, with loose granular sediments and an abundance of roots and historical debris. This layer was followed by a $21-\mathrm{cm}$-thick deposit of pinkish white fine to very fine sand along with cobbles and coralline gravel. From even more recent investigations, it appears that some areas are composed of shallow soil layers covering dredge materials, in contrast to perhaps less altered areas where the soil layer is deeper and underlain by sand (H. Young, Stanford University; J. Collen, Victoria University of Wellington, oral commun., 2008). There has been no known atoll-wide study with regard to soils, however, and the role that soils and soil quality are playing in the terrestrial ecosystem is uncertain. Uncertainties include the relation of soil to living organisms, such as plant distribution, and whether there are nutrient deficiencies affecting ecosystem integrity. For example, the presence or absence of mycorrhizae in the soil may affect Pisonia grandis health. Recent studies have shown that Palmyra's coral-derived soils are broadly nutrient deficient and vary significantly in nutrient levels across forest types (H. Young; written commun., 2009; Young and others, 2010a). They found the loss of allochthonous subsidies from sea bird-derived inputs in coconut palm forests compared to sites dominated by Pisonia grandis and tree heliotrope where birds prefer to nest and roost. While they found no significant difference in soil nutrients in Pisonia grandis and tree heliotrope forests whether they were from "natural" islets or those created from dredge fill, they found significantly lower nutrients on dredge fill islets versus "natural" when dominated by coconut palms. In addition, they found corresponding differences in trace elements by forest type with 5 of the 12 tested differing significantly.

As with groundwater, investigations for soil contaminants occurred at areas subject to FUDS remediation. Soil samples were taken at these locations, and any measurable contaminants found were considered at low enough levels for safe human use of the area. The soil samples were not tested for potentially negative effects to biota, though it was mentioned that a small site was determined to be at low ecological risk of contamination. The investigators found some soil contaminant "hot spots" but determined that remedial restoration was unnecessary unless the areas were intended for human habitation (Wil Chee Planning Inc. and SCS Engineers, 1998). Investigators considered continued terrestrial and marine organism use of the area to indicate minimal ecological risk; however, further remedial actions were recommended at several sites (Environmental Chemical Corporation, 1998; Wil Chee Planning Inc. and SCS Engineers, 1998).

Preacquisition studies conducted by the FWS in 2000 revealed elevated levels of metals, polychlorinated biphenyls (PCBs), and semivolatile petroleum hydrocarbon compounds, as well as slightly elevated arsenic levels, at terrestrial and intertidal locations. It was suggested that additional sampling be carried out to delineate the nature and extent of contamination. At that time, it was expected to cost about $\$ 28,000,000$ for additional remediation of identified emergent land areas (Woodward, 2000). In response to the FWS, the U.S. Army Engineer District, Honolulu acknowledged that they had undertaken approved remediation activities and that if funding became available in accordance with FUDS guidance and headquarters approval they would further remediate the sites identified as still contaminated at Palmyra Atoll. This sampling/remediation has not yet taken place; however, other contaminant surveys have recently begun, and preliminary results are pending (D. Papoulias, U.S. Geological Survey, oral commun., 2008). It is not known whether there are still problem areas or how they are affecting ecosystem integrity. As mentioned with respect to groundwater, it is unclear whether the nuclear testing conducted by Great Britain and the United States 
in the 1950s and 1960s at nearby Malden and Christmas Islands might have resulted in radioactive contamination at Palmyra Atoll because of fallout (Aronson and Anderson, 2000; Woodward, 2001). The FWS considered the need for testing for radioactive materials and determined it was not a major issue of concern at the time of their assessment (Woodward, 2001).

\section{Flora}

There are records of collections and descriptions of the vascular flora of Palmyra Atoll dating at least as far back as 1873 (Streets, 1877; Rock, 1916, 1929; Dawson, 1959; Herbst, 1988, 1992; Depkin, 2002; Freeman, 2006a, b). The most recent surveys, completed by Derral R. Herbst in 1987 and 1992 (and subsequent identification of two additional species sent to him in 2002), provide a vascular plant species list and a brief description of the primary plant associations. These were later updated by Freeman $(2006 a, b)$. According to Herbst $(1988,1992)$ three main vegetation associations - including Pisonia grandis forest, coastal strand forest (Scaevola-Tournefortia), and coconut palm forest-were observed on the islets. Other minor vegetation types occurred but were so small that they would not be plotted on a conventional vegetation map (Herbst, 1992). Some quantitative descriptions of species abundance and distribution exist within these records, but there are limits to our ability to quantify how vegetation has changed across Palmyra Atoll over time.

Records indicate as early as 1862 the presence of coconut palms and what Rock (1916) concludes was likely either Pisonia grandis or Suriana maritime and that food plants were being introduced to the atoll (report from Zenas Bent while he was there under commission by King Kamehameha IV to take possession of Palmyra under the Hawai ian flag [Rock, 1916]). Following Rock's (1916) account describing 15 species of vascular plants, including coconut palms (which many assume to be a Polynesian introduction), many additional species were added to the list of native and nonnative species. ("Native" refers to plants that arrived without the aid of humans). Some of the species added to this list were likely present when Rock visited in 1913 but were not encountered or not recognized at the time. The native Guettarda speciosa was collected on the atoll in 1949, but several other species were not recorded until much later. These species include Cordia subcordata, Hernandia sonora, and Barringtonia asiatica (Herbst, 1988, 1992), and it has been assumed that they arrived at Palmyra Atoll relatively recently without human intervention. While unlikely to give a complete prehistoric snapshot of the flora of Palmyra Atoll, paleoecological techniques of collecting and analyzing fossil pollen could help resolve some of the uncertainties of what species were present over time.

The practice of introducing and cultivating plants for food and as ornamentals continued until recently (Freeman, 2006a), but the list of unintentional introductions is also large. Some introduced plant species were unable to persist, but many are naturalized. The total vascular flora identified in past and current records at Palmyra Atoll includes 129 species. Of these species, 25 are considered native (2 of these may now be locally extinct); 48 were cultivated ornamentals or food plants; and 56 were adventive or naturalized (table 1, table 2) (Herbst, 1988, 1992; Freeman, 2006a, b). Reviewing recent assessments of the number of terrestrial vascular plant species known to be present on Palmyra Atoll, Freeman (2006a) suggests that 78 vascular plant species were still present on the atoll in 2006 . Twentyfive of these were considered native species, meaning 53 nonnative species were considered still present. In reviewing the recent overall species lists drafted, however, several species had contradictory information regarding their current status, and it may be that some species are still present while others have since gone locally extinct or been extirpated. One species, Lepturus repens var. palmyrensis is considered endemic to Palmyra Atoll. A list of previous collectors of the vascular plants of Palmyra Atoll (from Herbst, 1992) is presented in table 3, and lists of vascular plants known to be recorded from 
Palmyra Atoll with generalized indication of the extent of islet distribution and abundance as begun by Herbst (1992) and updated by Freeman (2006a) are presented in tables 1 and 2. For more detailed information for each species by islet see Freeman (2006a).

\section{Dominant Vegetation Types}

The aseasonal climate with high precipitation and warm temperatures on Palmyra Atoll supports dense vegetation of native and nonnative trees, shrubs, and herbaceous understory plants. Mapping efforts from 2001 imagery (Wegmann, 2005) estimated that a large portion of the atoll (about 43 percent) lies under a canopy of possibly nonnative coconut palm followed by native beach naupaka (Scaevola sericea) and tree heliotrope (about 29.5 percent) and Pisonia grandis (about 12 percent). Other vegetation types include broadleaf forests dominated by possibly nonnative tropical almond (Terminalia catappa) (about 6.2 percent), possibly nonnative hau (about 0.5 percent), and native Pandanus fischerianus (Wegmann, 2005). Understories include Lepturus repens grassland, Phymatosorus scolopendria stands, and bare ground (Wegmann, 2005). The vegetative zonation at Palmyra Atoll is spatially influenced by windward-leeward exposures and soil-groundwater influences. Natural temporal succession within these communities has been shaped by biophysical interactions and natural disturbance regimes from strong winds and cyclones, precipitation, sea bird-derived nutrients, and herbivory.

\section{Pisonia grandis Forest}

Pisonia grandis is a large, fast growing tree with soft wood reaching heights of $25 \mathrm{~m}$ on Palmyra Atoll (Herbst, 1992). The distribution of Pisonia grandis is limited to small remote islands in the Indian and Pacific Oceans (Airy Shaw, 1952) and was described in the 1890s as one of the "commonest most conspicuous forest types on coral islands throughout islands visited by the U.S. Fisheries Commission Albatross cruises" as reported by Alexander Agassiz (in Fosberg, 1994). It is now considered to be in widespread decline largely because of human activities (Walker, 1991). Individual trees reproduce almost entirely vegetatively, though they have sticky seeds thought to facilitate long-distance dispersal by remaining attached to sea birds (Burger, 2005). Carlquist (1974, in Walker, 1991) found little Pisonia grandis genetic differentiation across its Pacific range, suggesting that bird dispersal was effective enough at reintroducing genes to overcome local incipient speciation. This genetic evidence suggests an additional importance beyond the short-term benefit sea birds provide by adding nutrients to the system via guano; they may be increasing plant species genetic diversity over a long time period by dispersing seeds.

The factors influencing the pattern of distribution and growth of Pisonia grandis preclude a simple explanation. For instance, Pisonia grandis is found on both very wet and very dry atolls, with and without guano inputs. Walker (1991) suggests multiple contributing factors, including low dispersal frequency, guano effects, precipitation patterns, competition, insect grazing, genetic variation, and mycorrhizal associations. He points out that Pisonia grandis would likely be dispersed widely by sea birds through uncharacteristic dispersal events, such as cyclone scatter of sea birds; however, on islands in relative proximity to one another Pisonia grandis may be present on one island and absent on another. While it has been suggested that Pisonia grandis requires guano for growth, its distribution shows that this is not necessarily the case provided the soil contains adequate nutrients (Wiens, 1962; Spicer and Newberry, 1979). Pisonia grandis is found at the wettest (for example, about 4,500 $\mathrm{mm} / \mathrm{yr}$ at Palmyra Atoll) and very dry islands (for example, Vago Island about $70 \mathrm{~mm} / \mathrm{yr}$ ) (Bell, 1969, in Walker, 1991). As mentioned previously, Walker (1991) suggests that Pisonia grandis has very shallow roots adapted for using near surface water. Keith (in Airy Shaw, 1952) describes Pisonia 
grandis as intolerant of shade and competition. In fact, vegetative growth does not appear to be hindered by herbaceous competitors, as Pisonia grandis resprouts readily under dense Phymatosorus scolopendria at Palmyra Atoll (S. Hathaway, K. McEachern, and R. Fisher, U.S. Geological Survey; W. Smith, U.S. Fish and Wildlife Service, oral commun., 2008). Walker (1991) suggests that Pisonia grandis competes with other woody vegetation by establishing a canopy more quickly than other species, as well as through modification of the soil $\mathrm{pH}$. Common $\mathrm{pH}$ ranges from coral sand at 8.3 to "normal humus" at 7.0 to Pisonia grandis humus at 6.0-4.0 (Fosberg, 1957). Walker (1991) also notes that Pisonia grandis may develop dominance in areas of nutrient-poor soils via a symbiotic relation with an ectomycorrhizal mycobiont (a mutualism between a plant root and a fungus). As summarized in Nonner and Woodward (2006), Schmidt and others (2004) found that Pisonia grandis appears to acquire nitrogen as ammonium when deposited bird guano (largely uric acid) rapidly hydrolyses to ammonium. Guano also degrades to nitrate which is generally of low availability for uptake and assimilation in plants. Through an ectomycorrhizal association, Pisonia grandis may be able to acquire transiently available forms of nitrogen that result from the degradation of uric acid. At least two species of mycobiont have been found in association with Pisonia grandis with one or both occurring with the majority of samples taken, although certain samples contained no mycobionts (Ashford and Allaway, 1985; Chambers and others, 2005). This association could give Pisonia grandis a competitive advantage over other species particularly in nutrient-poor soils. Pisonia grandis is largely associated with sea birds where nutrient input is high, and there is speculation that the ectomycorrhizae may protect the roots or perhaps use nutrients quickly before they are leached away by rains (Allaway and Ashford, 1984; Ashford and Allaway, 1985). Conversely, it is possible that Pisonia grandis takes advantage of nutrient-poor coral soils and becomes established and then attracts birds. This possibility would require that seeds (or viable branches) and mycobionts arrive together. Given the sticky nature of the Pisonia grandis seeds this would not be entirely unreasonable (Chambers and others, 2005). The presence of ectomycorrhizae at Palmyra Atoll and potential relation to the health of this tree are presently unknown (Nonner and Woodward, 2006).

Christophersen (1927) describes the vegetation from his visit in 1924 thus: "most of the islets composing Palmyra are covered by vigorous forests of coconuts and Pisonia fringed by Tournefortia on the beach crest." Herbst (1992) considers that the vegetation prior to human visitation was probably predominantly Pisonia grandis forest fringed by coastal strand forest and suggests that Pisonia grandis was probably largely cleared by Polynesians to establish coconut palm groves and possibly for firewood. These activities have happened to a greater or sustained extent across its range, leaving the current forest at Palmyra Atoll to be considered one of the best remaining Pisonia grandis forests worldwide, though it has recently been in decline. Other locations with Pisonia grandis forest have historically been described as having no other species of trees in the understory with little to no groundcover or with a fern understory (Hatheway, 1955; Kepler and Kepler, 1994). Likewise, Rock (1916) describes this fern understory as typically bird's nest fern, although the primary understory today (2010) is Phymatosorus scolopendria. Freeman (2006a) reports that botanists collecting plants as late as the 1990s did not observe the dense ground cover of Phymatosorus scolopendria ferns now common in many of the open stands and canopy gaps of the islands. Instead like Rock (1926), older reports indicate a more open understory and greater cover of bird's nest fern. Freeman 2006a hypothesized that the Phymatosorus scolopendria increase occurred after about 2000 possibly in response to changes in the ecosystem such as the rat eradication trial, the scale outbreak, storm overwash, weather, or some other atoll-wide environmental phenomenon, all of which may have contributed to the Pisonia grandis die off (2001-6) and thus widespread formation of light gaps. 
In 2001, the FWS began collecting quantitative vegetation data on Palmyra Atoll as a pre-rateradication baseline (Depkin, 2002). During this period, it was observed that the Pisonia grandis stands were declining. As the trees were more closely investigated, it became apparent that there was a high density of a nonnative scale insect, Pulvinaria urbicola (Depkin, 2002). It is thought that the Pisonia grandis decline is likely a stress response from elevated numbers of the introduced scale and their symbiotic relation with the introduced ant Pheidole megacephala (Handler and others, 2007). The direct and indirect effects of scale on plants were reviewed in Nonner and Woodward (2006) largely citing Vranjic (1997). Direct effects include depletion of nutrients, tissue damage, accumulation of honeydew that can promote sooty mold and thereby reduce photosynthesis, and the redirection of resources toward growing new shoots instead of roots. Gerhing and Bennett (2009) note that the paucity of studies makes it impossible to make conclusions regarding plant response to level of scale infestation. Similarly, Nonner and Woodward (2006) note that sooty mold was present on other plants at Palmyra Atoll but was largely absent from Pisonia grandis. These conditions still persist today (2010). Indirect effects of the scale insect can include a loss of root structure, resulting in desiccation and possibly loss of ectomycorrhizal associations that could impede nutrient uptake. These direct and indirect effects result in reduced plant health and potentially the death of the plant.

In response to the declines and at the height of the scale infestation, the FWS began conducting quarterly Pisonia grandis censuses, beginning in 2004, to examine tree health and presence of scale (Nonner, 2005, in Nonner and Woodward, 2006, 2008; Nonner and Woodward, 2006). The FWS found that numbers of Pisonia grandis trees declined 34 percent between 2002 and 2005 with an areal extent reduced from about 12 percent to about 8 percent of the atoll and the greatest loss being larger trees (Nonner and Woodward, 2006).

Ants have been implicated in the increase of scale numbers because of a facultative relation in which they consume honeydew produced by scale and thus tend scale (Way, 1963). Pilot studies testing methods for ant control by using techniques tried in Australia began at Palmyra Atoll in 2004 (U.S. Fish and Wildlife Service, 2004). The FWS reported success in suppressing ant numbers and saw precipitous declines in ant populations on treatment islands (Nonner, 2005, in Nonner and Woodward, 2006; Freeman, 2006c, in Nonner and Woodward, 2006). They also reported no decline in scale densities when ant eradiation occurred. At the same time, researchers examined leaves to measure parasitism rates by Hymenopteran wasps, Coccophagus ceroplastae and Metaphycus flavus, known to be scale parasitoids present at Palmyra Atoll. Once ants declined as a result of treatment, the researchers indicated there was no increase in parasitism of scale and suggested that ants do not play a critical role in limiting wasp parasitism. This was consistent with observations previously reporting that parasitoids may not be effective at high scale densities (Freeman, 2006c, in Nonner and Woodward, 2006). These ant trials were only attempted on two islets, however, and full reports were unavailable. Consequently, there remains some uncertainty regarding results and many questions about how the treatments might be replicated. The results are of particular interest in determining how the successful reduction or eradication of several nonnative invasive ant species may benefit other species and processes in the long term; however, it has been suggested that the amount of bait required for these treatments, and the difficulty in keeping nontarget species from the bait, might make this technique prohibitively expensive and difficult (A. Wegmann, University of Hawai i, oral commun., 2008). These ants do not penetrate intact natural habitats (Wetterer, 2007). A recent study found that Pisonia grandis monocultures showed clear limitation of ant distribution and suggested it is the quality as well as quantity of carbohydrate supply this plant harbors that may be limiting invasive spread of this ant species (Hoffman and Kay, 2009). The study suggests that an increase in larger healthy stands of Pisonia grandis may be the best defense against this particular ant species. 
In 2005, the scale insect began to decrease atoll-wide, and an increase in the numbers of Pisonia grandis was recorded. By 2006, an increase in canopy cover was observed, although Nonner and Woodward (2006) considered that it was possibly due to reallocation of resources from root to shoot growth. By 2007, Pisonia grandis was considered to be in recovery with only patches of high scale densities remaining (Nonner, 2008). The FWS has shown a correlation between scale and tree health, but other contributing factors may have been involved, such as something causing an initial weakening of the trees making them more vulnerable to scale.

In 2007, the FWS began to investigate imidicloprid (an insecticide for the control of sucking insects) uptake in Pisonia grandis leaves and the longevity of treated leaves in infected trees compared to leaves of untreated infected trees and uninfected trees. In addition, the FWS tested whether imidicloprid would be effective in killing scale on individual trees or curbing spread from scale "hotspots" to nearby uninfected areas (Nonner, 2008). This trial was only applied at one location over a short time period during an apparent overall decline in scale numbers, however, so it is difficult to infer general results, and full reports were unavailable. The last census or systematic assessment was conducted in 2007 making quantitative analysis impossible. Recent (2008) qualitative examination revealed continued general recovery of Pisonia grandis, including regrowth. Chlorosis was evident in some areas (the southern complex of islets and was apparent in some of all tree species encountered), and other Pisonia grandis trees still had some patches of relatively high scale density (McEachern and Hathaway, 2008; W. Smith, U.S. Fish and Wildlife Service, oral commun., 2008).

Greenslade (2008) reviewed the decline of Pisonia grandis across its range, which began in the 1990s and was attributed to scale outbreaks. Control measures, including systemic insecticides (for example, imidicloprid), poisoning ants, and biocontrols [for example, releasing predatory invertebrates such as lady bird beetles (Cryptolaemus montrouzieri)] were used to ameliorate the scale outbreak in some of these areas, yet scale numbers fell within months even in control areas, suggesting that pest decline was a natural phenomenon. Greenslade (2008) cautioned against using methods of biocontrol in the event of additional pest outbreaks. While biocontrols have been successful and beneficial in some circumstances, they have had unpredictable and damaging effects in other cases (as found citing Kuris, 2003, and references therein).

Greenslade's (2008) evaluation emphasizes the importance of developing regionwide collaboration and coordination in management and monitoring of resources. The Pisonia grandis declines occurred over widely separated areas subject to different abiotic and biotic influences, suggesting that the declines were likely due to a widely occurring phenomenon such as climate variability. Greenslade (2008) suggests that stresses due to climate variability — such as rising sea surface temperatures, increased frequency and depth of El Niño events, and increased drought-may have been directly responsible for changes in freshwater availability for the trees. Likewise, cascading effects could have resulted from lower prey availability for sea birds, which would in turn reduce the availability of nutrients to Pisonia grandis. Greenslade (2008) emphasizes the importance of risk assessments, taking into consideration the total fauna, as well as considering that if the pest outbreak is due to climate variability it might not be desirable to use biocontrols but to let the system reach its own equilibrium. Much remains unknown regarding Pisonia grandis declines globally, management for this species worldwide, and specifically management at Palmyra Atoll. The varied scenarios above illustrate the value of conducting assessments to evaluate broader phenomena that can be relevant to local, regional, and global systems.

At Palmyra Atoll, these dramatic Pisonia grandis declines have impacts that resonate throughout the ecosystem. Relevant to these declines are natural history characteristics. As trees within Pisonia grandis stands fall, they leave gaps. In response to a recent storm event that broke branches and toppled 
trees, Herbst (1992) noted that trees reproduce vegetatively and under suitable conditions will recover within a decade, reaching maximum height in two or three decades. There appears to be a similar response after scale declines. However, in addition to these kinds of events reducing Pisonia grandis health and distribution, other pressures may reduce Pisonia grandis recovery. It was particularly noted during the recent decline that Pisonia grandis have been competing heavily with coconut palms to dominate newly opened areas. It is hypothesized that the invasive coconut palm does not provide habitat for guano-producing sea birds to roost and nest. This circumstance may further facilitate invasion by coconut palms, a species perhaps better equipped to take advantage of nutrient-poor soils than native plant species (H. Young, Stanford University, oral commun., 2008).

\section{Coastal Strand Forest or Scaevola-Tournefortia}

Native beach naupaka and tree heliotrope are the dominant species of the coastal strand vegetation type. Beach naupaka is more dominant on lagoon borders, and tree heliotrope dominates on the ocean edges (Herbst, 1992). Both are considered widespread, halophytic, pioneer species, and they can be found in monotypic stands or codominant as well as in mixed forest (Niering, 1963; Kepler and Kepler, 1994). They are generally not dense enough to prohibit ground cover and appear to have no substrate preference (Fosberg, 1953). This vegetation type, specifically tree heliotrope, is heavily used by red-footed boobies for roosting and nesting and is comparable to Pisonia grandis in native bird use overall (Young and others, 2010a). Tree heliotrope is less abundant across the Pacific than it was formerly (Kepler and Kepler, 1994). Kepler and Kepler (1994) report that most mature tree heliotrope occur at the tree heliotrope -Pisonia grandis interface but die off as Pisonia grandis expands. Geckos have been observed drinking the nectar from tree heliotrope flowers (S. Hathaway and R. Fisher, U.S. Geological Survey, oral commun., 2007), and Rock (1916) reported that crabs feed on the flowers. Fosberg (1953) noted that bristle-thighed curlews (Numenius tahitiensis) transport the seeds of beach naupaka, and Herbst (1992) noted that beach naupaka is the dominant species on Barren Islet with only a few coconut palms and tree heliotrope present, suggesting that it represents a very early successional stage. Usinger and La Rivers (1953) reported that both beach naupaka and tree heliotrope at Arno Atoll have their own insect species fauna.

\section{Pandanus fischerianus}

As observed by Fosberg (1953) elsewhere, though not common or large in extent, small groves of dense native Pandanus fischerianus are scattered throughout Palmyra Atoll. There were records or collections of Pandanus fischerianus from 20 islets in 2006.

\section{Lepturus repens var. palmyrensis}

One of the other native but minor vegetation types occurring at Palmyra Atoll includes small patches of native grassland. This grassland is composed of Palmyra Atoll's only endemic species, Lepturus repens var. palmyrensis (Herbst, 1992). It is closely related to taxa found on Malden and Christmas Islands as well as Pokak and Wake Atolls (from Herbst, 1992).

\section{Coconut Palm Forest}

The possibly nonnative coconut palm is likely the result of early introduction by Polynesian explorers to Palmyra Atoll. There was subsequent expansion through plantings occurring prior to and during military occupation and continuing to at least 1957 (Dawson, 1959). While this species could have arrived on its own, it is very clear that its distribution has been increased with human help. In addition, the coconut palm has displayed invasive behavior, increasing from about 9,600 coconut palms 
in 1886 to about two million currently (Rock, 1916; A. Wegmann, University of Hawai i, oral commun., 2008). Coconut palm forest is now the dominant forest type at Palmyra Atoll. It rapidly colonizes canopy gaps opened in other forest types (Herbst, 1992; Freeman, 2006a), and ongoing research by Hillary Young of Stanford University indicates that coconut palms may outcompete native species for nutrients. In addition, Young has found that the large nuts and fronds cause physical damage to native species when they fall, allowing for further expansion of established coconut palm groves.

Data collected recently regarding coconut palm use as habitat by native animal species are still being analyzed; however, it seems clear that few birds use coconut palms for roosting and even fewer for nesting (Young and others, 2010a). It is clear that the coconut palm forest provides abundant food and habitat for nonnative black rats (Rattus rattus), and the fruits are used as a food source by coconut crabs (A. Wegmann, University of Hawai i, oral commun., 2008). Data collected for all crab species are pending (A. Wegmann, University of Hawai i, oral commun., 2008), and data collection for geckos (R. Fisher and S. Hathaway, U.S. Geological Survey, oral commun., 2008) must continue in order to draw any conclusions about trophic interactions within the coconut palm groves (A. Wegmann, University of Hawai i; R. Fisher and S. Hathaway, U.S. Geological Survey; H. Young, Stanford University, oral commun., 2008). As yet, there are no habitat assessments for other terrestrial species, but use of coconut palm by other invertebrate species in addition to crabs may be of interest. The abundant evidence of elevated seed predation of native seeds in coconut palm -dominated sites relative to other forest types further suggests significant cascading effects of coconut palm forest dominance throughout the larger Palmyra Atoll system (H. Young, Stanford University, oral commun., 2008).

\section{Terminalia catappa}

The history of tropical almond (Terminalia catappa) at Palmyra Atoll is unknown, but it is generally regarded as a nonnative invasive species. Dawson (1959) described tropical almond and other species as being purposely introduced through original plantings on Menge Islet. It is the dominant tree in several groves on Cooper Islet, particularly near the TNC camp, but it apparently has not yet spread in large numbers to other islets. Tropical almond should be considered for control plans similar to the plans suggested for coconut palms. At minimum it should be monitored to examine how quickly it is expanding in distribution.

\section{Hibiscus tiliaceus}

The history of hau (Hibiscus tiliaceus) at Palmyra Atoll is also unknown, but it is also regarded by some as a nonnative invasive species. Dawson (1959) describes this and other species as being purposely introduced through original plantings on Menge Islet. Small, very dense, monotypic hau groves are scattered on several islets in the atoll. In addition, there is a nearly impenetrable hau swamp in the central portion of Pelican Islet and another smaller hau swamp on Home Islet. The rate of spread of hau is unknown; expansion should be monitored and control plans considered.

\section{Miscellaneous Species}

In addition to the aforementioned vascular plants, two species of terrestrial algae, three mosses, eight lichens, and four fungi species have been identified at Palmyra Atoll (Rock, 1916; Dawson, 1959; Herbst, 1992). 
Vegetation Monitoring

Aside from the Pisonia grandis censusing, quantitative vegetation surveys were completed only once at Palmyra Atoll, and the methods used may no longer be repeatable because of the difficulty in relocating the original points (Depkin, 2002). In 2007 Hillary Young (Stanford University), however, began multiple investigations on Palmyra Atoll, including an effort to identify changes in plant communities. Young's work can be expanded upon for baseline data collection and to establish shortand long-term vegetation monitoring.

With the implementation of management actions planned for Palmyra Atoll, including eradication of introduced black rats and the control of coconut palms, there are likely to be significant impacts on the vegetation. These actions are inevitably going to cause changes in the ecosystem, presenting challenges and opportunities for conservation and recovery. The challenges of managing a rapidly changing ecosystem in response to management actions and potential responses to factors such as climate change, present the opportunity to learn through observing responses in the floral and faunal community and investigating management effectiveness. There is a local and global need for the qualitative and quantitative monitoring of resources at Palmyra Atoll to learn how such changes impact the ecosystem.

\section{Fauna}

Streets (1877), Rock (1916), and Dawson (1959) provide some early descriptions of the fauna inhabiting the terrestrial ecosystem at Palmyra Atoll. As with plants, the species lists have been built upon over time. There are no terrestrial mammals native to Palmyra Atoll, but there are various native birds, lizards, arthropods, and crabs, as well as several nonnative vertebrate and invertebrate species that have been inventoried through the years.

\section{Mammals}

As mentioned, there are no terrestrial mammals native to Palmyra Atoll, but several mammals have been introduced over time intentionally and unintentionally (table 4). It is unknown when or what the first nonnative mammal introductions were, but the most detrimental has undoubtedly been the black rat which will be discussed further (see Invasive Species). Flint and others (1992) reported pigs (Sus domestica) and a dog (Canis familiaris). Other nonnative mammals have included cats (Felis catus). At present (2010), two domestic cats and one domestic dog are cared for by TNC and restricted to Cooper, Menge, and Strawn Islets. Feral cats continue to be sighted periodically (S. Hathaway and R. Fisher, U.S. Geological Survey, oral commun., 2007; W. Smith, U.S. Fish and Wildlife Service; H. Young, Stanford University, oral commun., 2008).

\section{Avifauna}

Palmyra Atoll National Wildlife Refuge is the only site left for Pisonia grandis-dependent sea birds within the Northern Line Islands (Flint, 1999). Sea birds are marine foragers and travel long distances (for example, red-footed boobies can exceed $200 \mathrm{~km}$ per day [Young and others, 2010c]), returning to Palmyra Atoll to rest and breed. The terrestrial habitats on Palmyra Atoll support 10 species of breeding sea birds considered resident species and 4 others considered rare visitants (Fefer, 1987; A. Wegmann, University of Hawai i, oral commun., 2008; table 5). In addition to their important role of dispersing seeds, sea birds are important drivers in the ecosystem, bringing marine-derived nutrients in and producing copious guano. To a lesser extent, sea birds provide nutrients used throughout the food chain, in the form of feathers, regurgitated fish, and bird, chick, and egg carcasses. 
The distribution, population, status and trends, ecology, and conservation concerns for these sea bird species can be found in the "Regional Seabird Conservation Plan, Pacific Region" (U.S. Fish and Wildlife Service, 2005). The greatest threats to sea birds at Palmyra Atoll locally to globally include introduced black rats and other invasive species, fishery interactions, contaminants, marine debris, and climate change. In fact, it is believed that black rats may be responsible for the current lack of burrownesting sea bird species on Palmyra Atoll. Species such as wedge-tailed shearwaters (Puffinus pacificus), Audubon's shearwaters (Puffinus lherminieri), and Polynesian storm-petrels (Nesofregetta fuliginosa) have been observed offshore (Depkin, 2002; J. Smith, University of Washington; M. McKown, University of North Carolina; E. Flint, U.S. Fish and Wildlife Service; L. Balance, National Oceanic and Atmospheric Administration; R. Pitman, National Oceanic and Atmospheric Administration, oral commun., 2008) or collected on the atoll (that is, Smithsonian Institute; USNM 496523; petrel specimen from 2008, Matthew McKown) in the past, but we found no records of residence on the atoll.

Palmyra Atoll also supports overwintering populations of shore birds including bristle-thighed curlews, Pacific golden plovers (Pluvialis fulva), wandering tattlers, (Heterscelus incanus), and ruddy turnstones (Arenaria interpres). The bristle-thighed curlew and Pacific golden plover are designated by the FWS shore bird conservation plans as species of high conservation concern in national and regional shorebird plans, including the "U.S. Pacific Islands Regional Shorebird Conservation Plan" (Engilis and Naughton, 2004). They are also designated Birds of Conservation Concern by the FWS at the regional and national scale (U.S. Fish and Wildlife Service, 2002) because of limited breeding and nonbreeding distributions, low relative abundance, and a decline in populations. Both of these species overwinter on Palmyra Atoll, with some individual juvenile birds present throughout the year.

There are currently no records of breeding land birds on Palmyra Atoll. Two nonnative bird species are known to have been introduced to Palmyra Atoll. The crested mynah (Acridotheres cristatellus) has been reported as an introduced but now extirpated species at Palmyra Atoll (R.B. Clapp, U.S. Geological Survey, written commun., 1966, in Fefer, 1987). Domestic chickens (Gallus gallus) were also reported (Flint and others, 1992) but are no longer present.

\section{Herpetofauna}

There are six terrestrial herpetofauna species recorded from Palmyra Atoll (table 6). These include an undescribed native gecko species of Lepidodactylus $n$. sp., the potentially nonnative mourning gecko (Lepidodactylus lugubris) (a parthenogenic species represented on the atoll by many different clone types, of which there may be native and nonnative clone types), and an introduced house gecko (Hemidactylus frenatus). The house gecko is suspected of transferring parasites to at least the mourning gecko (R. Fisher and S. Hathaway, U.S. Geological Survey, oral commun., 2007). Current studies are underway to investigate the distribution and habitat use of all three gecko species to gather baseline information and consider nonnative species eradication (Fisher and Hathaway, 2007). One nonnative amphibian, the marine toad (Bufo marinus), was historically present on Palmyra Atoll but has not been observed since 2002 (S. Barclay, U.S. Fish and Wildlife Service, oral commun., 2008).

Two species of sea turtles, the federally endangered hawksbill (Eretmochelys imbricata) and threatened green turtles (Chelonia mydas), are found at Palmyra Atoll with green turtles being the more common species (Fefer, 1987; E. Sterling, American Museum of Natural History, oral commun., 2008). Both species of sea turtles are known to forage at Palmyra Atoll, and nesting has been documented at least twice for green turtles (Fefer, 1987; Depkin, 2002). Scientists from the FWS, American Museum of Natural History, and recently USGS have conducted surveys targeting species abundance and distribution in the eastern lagoons where sea turtles are most prevalent. Green turtles typically nest on 
sandy beach habitats but may be prevented from nesting and laying eggs at Palmyra Atoll. One hypothesis for the lack of nesting may be the extreme abundance of coconut palms close to the beach where green sea turtles might otherwise attempt to dig nesting pits (Suchanek and others, 2007). This hypothesis could be tested experimentally by developing a study design and monitoring program in conjunction with the proposed coconut palm control design (app. 1) targeting areas of sandy beach. Sea turtle hatchlings are vulnerable to rat predation (Caut and others, 2008); therefore, the success of this management action may hinge on black rat eradication.

\section{Terrestrial Invertebrates}

Arthropods

Palmyra Atoll supports a few native and many accidentally introduced nonnative insects (Handler and others, 2007) (table 7). Little is known about the native species and their distributions and abundance across the atoll. The most detrimental nonnative insects include several ant species, a species of scale, and mealy bugs. The most extensive distribution data available include the presence of scale recorded during Pisonia grandis censuses and an informal survey of the distribution of whiteflies, scale, mealy bugs, and aphids. In the latter survey, it was found that only 9 percent of plant species surveyed were uninfested, and most observed plants harbored white fly (67 percent). In addition, 40 percent of plant species harbored mealy bugs, 28 percent harbored scale, and 18 percent harbored aphids (Freeman, 2006a). Recently, additional studies have been undertaken to collect more data on the distribution and abundance of insects in general; however, these data have not yet been analyzed $(\mathrm{H}$. Young, Stanford University, oral commun., 2008).

Palmyra Atoll also supports six species of native terrestrial crabs, including the coconut crab (Birgus latro), two species of land hermit crabs, two species of land crabs, and the brown tree climbing crab (Geograpsus crinipes) (table 8). These crabs play an important role in reducing organic matter and mixing soils, as well as dispersing seeds (Wiens, 1962; A. Wegmann, University of Hawai i, oral commun., 2008). Niering (1963) found that crab occurrence at Kapingamarangi and Caroline Islands correlated with soil friability and surface debris rather than with any vegetation type and found more burrows lagoonward. The existing data for all terrestrial crab species found at Palmyra Atoll are limited, but there is a slightly larger body of information for the coconut crab compared to the other crab species.

The coconut crab, considered the largest terrestrial arthropod, is distributed across the IndoPacific (Reyne, 1939; Lavery and others, 1996). Over the past several years, populations have declined because of overharvesting and (or) habitat modification or destruction in many regions, and the coconut crab has become regionally extinct from Mauritius (Wells and others, 1983). Although progress toward sustainable use has been made in several countries, this species maintains an International Union for Conservation of Nature (IUCN) listing of "Data Deficient," and information on natural populations remains sparse (Eldredge, 1996). There is little known about this species globally and even less locally. Palmyra Atoll is an uninhabited national wildlife refuge where coconut crab harvesting is prohibited, making it an ideal location to study the natural variation in coconut crab populations and responses to ecosystem changes, as well as the intentional or unintentional impact of management actions.

The coconut crab digs shallow burrows for mating and molting and frequently maintains several burrows within a territory. The species is omnivorous and will scavenge carcasses, climb trees to access food or escape, and can live to over 40 years. Because it is highly sought after for human consumption, it is rare on all inhabited islands and considered an imperiled species. Rock (1916, p.16) noted that the 
coconut crab "abounds in great numbers" and went on to note that the species eats their "brother crab." At present, the coconut crab is the least abundant crab at Palmyra Atoll (Howald and others, 2004).

Limited quantitative data from four islets indicate variability in coconut crab densities at Palmyra Atoll (Howald and others, 2004). Qualitative differences in coconut crab numbers around the atoll indicate that only a few islets currently support relatively large numbers of crabs. This variability may be mediated directly by the nonnative black rat. The black rat currently occupies Palmyra Atoll, and there is extensive literature regarding the negative impacts of these mammals on Pacific Islands (Towns and others, 2006). Rats and coconut crabs are omnivorous, and rats may compete with coconut crabs for resources. Coconut crabs may also modify their activity patterns from nocturnal to diurnal as a result of rat presence. It is unknown to what extent coconut crabs are impacted by rats at Palmyra Atoll, but evidence of predation (coconut crab carapace pieces in rat husking stations) has been observed (A. Wegmann, University of Hawai i; R. Fisher, U.S. Geological Survey, oral commun., 2008).

There are two species of land hermit crabs present on Palmyra Atoll. The most abundant crab species is the strawberry hermit crab, followed by the purple hermit crab (Coenobita brevimanus) (Howald and others, 2004). These crabs use a gastropod shell (or other covering) to protect their unarmored abdomen and retain water to prevent desiccation. Both crabs are omnivorous scavengers and are generally nocturnal; however, they are active diurnally in humid regions such as Palmyra Atoll. Rock (1916) reported "multitudes" of hermit crabs climbing the trees and eating tree heliotrope flowers, as well as eating conspecifics.

There are two species of land crab, the orange land crab and the purple land crab (Cardisoma rotundum) on Palmyra Atoll. These species construct well-defined, deep burrows in soft soils and go below the water table to keep the lower portions of their burrows moist. They are primarily herbivorous but will also scavenge.

Though no additional information could be located, the brown tree climbing crab has also been recorded at Palmyra Atoll.

Most terrestrial crabs are crepuscular or nocturnal to avoid desiccation; however, the aforementioned species have been observed to test the limits to consume easily available food (A. Wegmann, University of Hawai $i$, oral commun., 2008). In collaboration with Island Conservation, A. Wegmann's crab movement data from Palmyra Atoll showed no relation between crab numbers and proximity to vegetation or water, suggesting that observed daytime preference for particular habitats decreases when crabs are more active at night (A. Wegmann, University of Hawai i, oral commun., 2008). Wegmann also conducted an atoll-wide crab density survey for five species, surveying 5 percent of the emergent land area across the major habitat types. He found strawberry hermit crabs to be the most abundant crab species on Palmyra Atoll, no preference across vegetation types for any crab species, and that there was a general avoidance of open areas (Howald and others, 2004).

We know little about what might be affecting crab populations at Palmyra Atoll. Potential limiting factors include predation, competition for shells of sizes used by juveniles of Birgus and all life stages of Coenobita species, and burrow damage. Rats may also cause a reduction in crab populations because of predation and competition.

Streets (1877) reported other invertebrate species such as a bird eye leech and a land snail (Tornatellina). Though both have been observed recently the leech remains unidentified.

\section{Environmental and Human-caused Drivers and Stressors}

Numerous environmental and human-caused drivers have affected Palmyra Atoll in the past and may continue to affect ecosystems into the present. Some of the most prominent environmental stressors include impacts from climate change, such as increased storm frequency and intensity, sea 
level rise, and potential seawater intrusion into groundwater. Direct hazards from current and past human impacts include those which originated during military use, such as contaminants, scraping, dredge fill and debris, marine debris of various origins, and introduction of invasive species. Considering the relative and interacting impacts of these stressors, it is necessary to identify priority management needs in an ecosystem-based management approach.

\section{Storms}

While we may not know long-term patterns of the recurrence of large storms, they have been recorded as occurring in 1958, 1992, 2002, 2005, and 2007 (Dawson, 1959; Flint and others, 1992; Herbst, 1992; Brainard and others, 2005; TNC staff, Palmyra Program, oral commun., 2008). Dawson (1959) reported extensive damage to the islets from a severe storm in 1958 which resulted in nearly a meter of water washing over the atoll, collapsing buildings, washing away parts of islets, killing introduced plant species, and generally sparing only those species resistant to typhoons. According to National Oceanic and Atmospheric Administration (NOAA) records (in Brainard and others, 2005), three cyclones have been observed passing through the Exclusive Economic Zone of Palmyra Atoll in the past 60 years. One cyclone (Ekeka), recorded in 1992, registered as a Category One hurricane on the Saffir-Simpson Scale and reached wind speeds of over $100 \mathrm{~km} / \mathrm{hr}$. Flint and others (1992) and Herbst (1992) reported extensive damage to the atoll with the worst damage occurring in the Pisonia grandis forest where limbs were broken off and entire trees were blown down. In addition to felling trees, overland washes from storms can kill or thin coastal strand areas of beach naupaka and tree heliotrope. Though they found bird mortality difficult to quantify, Flint and others (1992) found bird carcasses pinned under trunks and limbs. Recent large storm events have also been capable of the removal of dredge fill and expansion of gaps between the islets, opening and enlarging channels between them. In some cases, storms have caused the outright disappearance of small "created" islets, and enlarging of islets has also been observed (Dawson, 1959; Collen and others, 2009; R. Fisher, U.S. Geological Survey, oral commun., 2008). Among other changes, these recent storm events have resulted in observed succession of Phymatosorus scolopendria ferns colonizing exposed highly organic soils within a few years. Even minor storms and winds can fell mature Pisonia grandis trees, creating small gaps within large contiguous "old growth" forests. Overall, the frequency and effects of these storms are unknown, but in recent years smaller wave events resulting from distant tropical and extratropical storms have occurred with greater regularity.

\section{Climate Change}

Changes in current patterns of precipitation and temperature are likely to alter community composition and ecosystem function as native species reach their physiological limits, food and other habitat resources become scarce, or competition from nonnatives increases. It is likely that tropical storms will become more intense in the future, with the higher windspeeds and heavier precipitation associated with ongoing increases of tropical sea surface temperatures (Intergovernmental Panel on Climate Change, 2007). Projection of the magnitude of sea level rise from thermal expansion of water and the melting of land-based ice sheets is less certain, but increases in sea level may affect low-lying equatorial islands and atolls within the next century. Sea level increase will likely speed shoreline erosion and will possibly result in complete inundation of Palmyra Atoll. No studies have been completed regarding the effects of climate change on the presence of subsurface freshwater aquifers or saltwater intrusion, although these phenomena have been noted throughout the Pacific (Shea and others, 2001). 


\section{Direct Human Impacts}

Military use in the 1940s resulted in unprecedented change to Palmyra Atoll. Unexploded ordnance and additional contaminants still remain (Environmental Chemical Corporation, 1998; Woodward, 2000, 2001; Brainard, 2005). Contaminant assessments and removal efforts were made following military occupation of Palmyra Atoll and prior to its transfer to the FWS refuge system. More recently, preliminary surveys (Woodward, 2000, 2001; Depkin, 2002; Suchanek and others, 2007) conducted broadly across the atoll determined that contaminant sources are still present. These sources are composed of chemical and physical agents that may threaten ecosystem integrity. There has been some atoll-wide mapping of known and potential sources of contamination, and there is a continued effort to update the source list to prioritize cleanup, develop management strategies, and implement remediation (D. Papoulias, U.S. Geological Survey, oral commun., 2008).

Many of the contaminant concerns are currently related to avifaunal populations, but further research into contaminant presence at Palmyra Atoll and the impacts of contaminants on native species is necessary. Finkelstein and others (2007) found correlations between high levels of organochlorines and elevated levels of mercury and impaired immune function in black-footed albatrosses. In addition, shore birds may ingest soil while foraging, and soil can constitute up to 30 percent of the material a bird consumes (Beyer and others, 1994; Hui and Beyer, 1998). If the soil is contaminated, this consumption results in the direct intake of toxic substances by foraging birds.

Marine debris is a global problem. It can be seen at Palmyra Atoll in various forms, including shoes, glass bottles, fishing nets, buoys, various plastics, and so on. Marine debris can have immediate negative impacts on animals because of entanglement and drowning, as well as injury and obstruction to the digestive tract (Spear and others, 1995; Henderson, 2001). Smaller items made of plastic can be ingested at sea by adult sea birds and subsequently fed to chicks, causing injury or mortality (Fry and others, 1987). Other studies indicate that ingestion of plastics may result in the assimilation of PCBs and other toxic chemicals (Ryan and others, 1988). There may be intermittent efforts to collect and dispose of marine debris at Palmyra Atoll, but no explicit protocol is currently in place.

Minimal urban footprint occurs presently, and it is restricted to Cooper and Menge Islets. The current (2010) use of Palmyra Atoll, however, includes vehicular activity, such as aircraft, trucks, tractors, backhoes, rollers, and a water tanker. The potential impacts of these vehicles may result in direct and indirect risks to terrestrial flora and fauna, including directly striking or crushing, potential crashes, and fuel spills. The main infrastructure at Palmyra Atoll includes 16 cabins, a galley, a row of three connected and several individual shipping container boxes used as refrigeration and storage rooms, a showerhouse, a restroom facility, a laboratory, offices, water catchment systems, a generator room, a dive locker, and a maintenance garage. This infrastructure supports up to 24 people at any given time. Other human activities in the terrestrial forest ecosystem include recreation, such as hiking, interpretive walks, research, and management actions.

The light and noise generated by human habitation and activity are of concern, as they may disorient various species and potentially cause injury or mortality. Sea birds may become disoriented and collide with lighted buildings or other nearby obstacles particularly during rain events. Turtle hatchlings could become disoriented and travel inland. There are management actions in place to reduce these impacts, including avoiding birds on nests where possible, minimizing the use of lights at night, and turning off lights during rain events at night when sea birds are most likely to become disoriented. Other protocols are in place to avoid bird airstrikes, which include actively keeping birds off the runway by approaching them and the use of loud sounds. 


\section{Invasive Species}

Nonnative and even native species have the potential to be invasive, defined by Executive Order No. 13112 as a species whose introduction has caused harm or may cause harm to environmental or human health (National Invasive Species Council, 2008). Invasive species are well known to be important factors in the decline of unique natural communities, species, and ecological processes inside and outside refuge boundaries (Vitousek, 1990; numerous papers in Veitch and Clout, 2002; Engilis and Naughton, 2004). Palmyra Atoll is home to various nonnative and invasive species, including plants, arthropods, and black rats.

The first invasive species to reach Palmyra Atoll are unknown but likely arrived with early movement through the area by Polynesians more than 1,500 years ago. It is widely believed, though not proven, that the first introduction of coconut palms happened in this way, and it is clear that additional plantings were made over the years (Rock, 1916; Dawson, 1959). The coconut palm now covers the majority of Palmyra Atoll, often in monotypic stands and at the expense of native species. There are several other invasive plant species, including koa haole (Leucaena leucocephala) and pothos (Epipremnum pinnatum), warranting investigation and prioritization for control and eradication (see Hathaway and Fisher, 2010).

Various species of nonnative arthropods including scale, mealy bugs, ants, mud daubers, and mosquitoes are all present on Palmyra Atoll, and their effects are poorly understood. There are 10 species of nonnative ants recorded from Palmyra Atoll (Handler and others, 2007), 3 of which are considered highly invasive - the big-headed, crazy, and ghost ants (Pheidole megacephala,

Paratrechina longicornis, and Tapinoma melanocephalum, respectively) (Pacific Invasive Ant Group, 2004). It has been hypothesized that scale infestations exacerbated by tending ant species are responsible for the massive recent decline of Pisonia grandis (Handler and others, 2007). The bigheaded ant is considered the most detrimental ant at Palmyra Atoll because of its association with scale; however, studies by Nonner and Woodward (2006) indicate that this may not be the case, at least at Palmyra Atoll. In addition, this species is known to displace most native invertebrate fauna through aggression (Wetterer, 2007). There is also a decrease in the abundance of vertebrates where the bigheaded ant is extremely abundant, and they can facilitate the invasion of introduced plant species.

Wasps and mosquitoes are also problems on Palmyra Atoll. Mosquitoes are of particular concern because they are potential vectors for various human and wildlife diseases. Two of the mosquito species, recently identified by Handler and others (2007), are clearly threats. The forest day mosquito (Aedes albopictus) has a wide host range including humans and birds and is a known potential carrier of dengue and West Nile virus (Kyle and Harris, 2008). The southern house mosquito (Culex quinquefasciatus) is a potential vector for avian diseases including avian malaria, avian pox, and West Nile virus (van Riper III and others, 2002; Ladeau and others, 2008).

Rats are well known to have severe effects on the ecosystems they invade, and there is extensive literature on the negative impacts of these mammals on Pacific Islands (for example, numerous papers in Veitch and Clout, 2002; Engilis and Naughton, 2004; Howald, 2004; Buckelew, 2005; U.S. Fish and Wildlife Service, 2005; Jones and others, 2008; Towns and others, 2009). They are thought to be responsible for the lack of burrowing nesters breeding on Palmyra Atoll, such as shearwater and petrel species that are often observed offshore (Depkin, 2002; J. Smith, University of Washington; M. McKown, University of North Carolina; E. Flint, U.S. Fish and Wildlife Service; L. Balance, National Oceanic and Atmospheric Administration; R. Pitman, National Oceanic and Atmospheric Administration, oral commun., 2008). They are also observed to be avid predators of ground nesting breeders at Palmyra Atoll, particularly sooty terns (Onychoprion fuscatus) (Fefer, 1987; A. Wegmann, University of Hawai i; H. Young, Stanford University, oral commun., 2008). While nesting events have 
rarely been documented at Palmyra Atoll for green turtles, it is worth mentioning that rats have been documented killing and consuming sea turtle hatchlings elsewhere (Caut and others, 2008). Further, black rats at Palmyra Atoll have been observed attacking land hermit crabs, and land crab carapace pieces are common items in rat husking stations (A. Wegmann, University of Hawai 'i, oral commun.; R. Fisher, U.S. Geological Survey, oral commun., 2008). It is also thought that rats reduce native plant species by consuming seeds and seedlings (Grant-Hoffman and others, 2010). Rat and crab seed and seedling predation experiments indicate that rats kill and disperse seeds where they will not germinate, whereas crabs manipulate seeds but do not kill them and disperse seeds randomly (A. Wegmann, University of Hawai' i, oral commun., 2008). Rats are also known to carry parasites, and recent studies have found that the parasites accompanying rats to Palmyra Atoll may use geckos as paratenic hosts (R. Fisher, U.S. Geological Survey, oral commun., 2008). The most consistent factor associated with abundance of these rat parasites (in rats) was found to be habitat provided by another potentially nonnative species, coconut palm (Lafferty and others, 2010). Fallen coconuts eaten by rats have also been shown to provide breeding habitat for mosquitoes elsewhere (Riviere and others, 1998).

TNC, in conjunction with the U.S. Department of Agriculture's Wildlife Services and the FWS, initiated rat eradication on Palmyra Atoll in 2001. This eradication program was an attempt to restore Palmyra Atoll's terrestrial ecosystem. It was suspended in August 2003 after it became apparent that rats would not be eradicated from Palmyra Atoll through the methods in use and that the program needed to be reviewed and revised. In the spring of 2004, Island Conservation and TNC secured funding to conduct a site assessment on Palmyra Atoll and develop specific recommendations, techniques, and options to complete the rat eradication. In August 2004, a team of people with experience in island rodent eradication or control visited Palmyra Atoll to gather enough information for trial eradication and to begin planning the successful eradication of rats from Palmyra Atoll (Howald and others, 2004; Buckelew and others, 2005). Radio telemetry data comparing movements of rats livetrapped in coconut palms with rats trapped on the ground revealed that rats on Palmyra Atoll regularly move between the tree canopy and the ground. The ranging or planar movements of rats captured on Palmyra Atoll were particularly small, leading researchers to believe that rats did not encounter or only infrequently encountered bait stations spaced at $50-\mathrm{m}$ intervals. The rat eradication program is an example of adaptive management already taking place at Palmyra Atoll. Rat removal was attempted, but it failed. Experiments were conducted to improve methods, and the resulting information will be used to determine why rat removal failed and to improve future plans. Planning is now underway to continue the removal program by using new evidence to increase success.

Other nonnative animal species include house geckos, which also may be responsible for transmitting parasites and outcompeting native geckos. These geckos are currently centered around the urban core on buildings, and new poison baits being developed in New Zealand might be appropriate for attempting removal experiments.

The prevention of nonnative species invasion, as well as eradication plans, are covered in greater detail in the "Biosecurity Plan for Palmyra Atoll" (Hathaway and Fisher, 2010).

\section{Conceptual Models of Palmyra Atoll Terrestrial Forest Ecosystems}

Conceptual models provide a vehicle for summarizing existing knowledge and making hypotheses about the components of a system and their interactions. These models assist in identifying resources of concern and limiting factors. In turn, this clarification allows identification of potential management and monitoring objectives, helps identify critical assumptions and uncertainties remaining to be resolved, and may help determine what management actions are most appropriate and effective for achieving management goals. The conceptual model for the terrestrial Pisonia grandis forest ecosystem 
presented here is based on the best available information and expert opinion and is being used to develop testable management hypotheses for conserving and restoring the forests. As with many aspects of adaptive management, these models are designed with the expectation of modification based on new information. As management and monitoring implementation proceeds, these models can be improved.

\section{Components of the Terrestrial Ecosystem on Palmyra Atoll}

Components of the terrestrial forest ecosystem include the physical environmental factors (precipitation, temperature, soil moisture and nutrients, and possibly groundwater) necessary to support the native Pisonia grandis forest, coastal strand forest, and grassland habitat mentioned in previous sections. These terrestrial forests in turn provide important habitat for the native fauna to rest, avoid predators, reproduce, and forage. This system includes bottom-up and top-down drivers of the flow of energy. For example, storms are major top-down drivers that reset the system through succession. Sea birds are also major biological top-down drivers because they deposit nutrients derived from the marine system into the terrestrial ecosystem (Polis and Hurd, 1996). Ongoing sea bird studies show that this holds true at Palmyra Atoll (Young and others, 2010a). The nutrient deposition by sea birds is just one example of how the terrestrial and marine ecosystems are highly interconnected. Disturbances occurring in the marine environment, such as a reduction in sea bird at-sea foraging resources, are likely to impact the terrestrial environment. Bottom-up terrestrial ecosystem drivers include invasive plant species that may displace native plants and create new forest types, storms that may occur with increasing frequency and intensity through global climate change, or saltwater intrusion into groundwater with rising sea level.

Understanding the components and processes involved in terrestrial ecosystem function is important to managing the ecosystem and facilitating management decisions. Upon implementation of management plans to eradicate black rats and control coconut palms, we hypothesize that there will be a change in ecosystem drivers that will lead to an increase in native forest. More native forest would lead to an increase in sea bird activity and increased nutrient input, which will reduce competition among plants for nutrients. We expect that leaf litter will increase with native forest recovery, facilitating soil development and bringing about increases in the abundance of invertebrate detritivores and more effective nutrient cycling. Similarly, the presence of a soil-litter habitat layer will encourage bottom-up trophic interactions among invertebrates and their predators.

\section{Resources of Concern}

Resources of concern can be modeled as components of the system, existing in a current state but having other desired future conditions or targets for management. Resources of concern are described in FWS 620.1 as "all plant and (or) animal species, species groups, or communities specifically identified in refuge purpose(s), System mission, or international, national, regional, State, or ecosystem conservation plans or acts" (http://www.fws.gov/policy/620fwl.html, accessesed September 1, 2009). For example, waterfowl and shore birds are a resource of concern on a refuge whose purpose is to protect "migrating waterfowl and shore birds." The Federal or State threatened and endangered species on that refuge are also resources of concern under terms of the respective endangered species acts.

In accordance with the intent behind FWS 620.1, resources of concern identified in this "Terrestrial Forest Management Plan for Palmyra Atoll" were considered within the context of FWS and TNC purpose, mission, and priorities as cited below along with their source documents: 
- “...to protect and preserve the natural character of fish, wildlife, plants, coral reef communities, and other resources associated with the tidal lands, submerged lands, and waters of Palmyra" (Palmyra Atoll National Wildlife Refuge was established [as stated in Secretary Order No. 3224])

- "...to administer a national network of lands and waters for the conservation, management, and where appropriate, restoration of the fish, wildlife, and plant resources and their habitats within the United States for the benefit of present and future generations of Americans" (The mission of the National Wildlife Refuge System)

- 'to preserve, protect, and restore Palmyra's unique ecosystem while facilitating valuable and responsible research through collaborative partnerships" (TNC Palmyra Program mission)

- "protection and enhancement of wildlife habitat" (TNC Palmyra Program management priorities)

The terrestrial ecosystem components listed in table 9 were identified as plant resources of concern through discussions with the FWS, including Pisonia grandis forest, coastal strand forest, and grassland (and their constituent native species). Likewise, animal species of concern have been grouped according to nesting habitat for avifauna and general habitat preferences for all other species and are presented in table 9. The resources identified in this document were chosen on the basis of review of published and unpublished information about the resources of Palmyra Atoll and in consultation with TNC and former and current FWS staff, as well as members of the Palmyra Atoll Research Consortium and other scientists (table 10). For each resource of concern, the current state and limiting factors are presented on the basis of qualitative observation. These designations may be adjusted as management and monitoring activities provide more information in an adaptive management feedback framework (Atkinson and others, 2004). The target states for these resources have been identified on the basis of reasonable desired future conditions, given what we know now about current conditions, ecological interactions, and discussion with the Palmyra Atoll land management agencies.

\section{Critical Assumptions and Uncertainties}

There is a level of uncertainty about causes of declines in ecosystem integrity and the appropriate management actions required to improve them. This uncertainty is caused by gaps in knowledge about the system. These gaps include knowledge of the historical range and distribution of many species on Palmyra Atoll, their specific habitat requirements, and the pressures that affect them. There are also uncertainties about the relations between the various vegetation communities and the ecological processes and pressures that drive system dynamics. For example, the decline of Pisonia grandis is thought to be related in varying degrees to scale infestations facilitated by ants, storm overwash, potential decreases in groundwater availability or quality, waterborne or soilborne contaminants, a possible paucity or lack of ectomycorrhizal mycobionts, and invasive species competition for space and nutrients, especially coconut palm, which also causes physical damage and promotes predation on young vegetative shoots by rats and crabs. It is assumed that improving and increasing habitat for native forest will have positive effects on other resources of concern. For example, we assume that if there are more native Pisonia grandis and tree heliotrope, there may be an increase in sea birds. Therefore, these uncertainties and assumptions do not prevent us from developing management actions to achieve desired future conditions. Rather, the uncertainties and assumptions are part of the management system, and they guide monitoring and management activities to reduce uncertainty about progress toward the target condition. 


\section{Conceptual Modeling}

Pisonia grandis forest is a resource of concern, but Pisonia grandis forest restoration is an objective nested within the overall management goal of maintaining and restoring the terrestrial ecosystem integrity of Palmyra Atoll. As an example of the conceptual modeling approach, we present a state-transition conceptual model for restoration of the Pisonia grandis forest (fig. 2). This model greatly simplifies all of the components of the forest ecosystem by focusing on identifying vegetation states. We expect management activities such as removal of nonnative species to cause a shift toward native forest better able to sustain itself without management assistance. This transition can be facilitated with the addition of native propagules, although seeds and seedlings may need protection from native and nonnative predators to become established. There are additional factors not included such as whether nutrients or ectomycorrhizae, which may be integral to Pisonia grandis restoration management but are absent or deficient, should also be considered. We identify several ecosystem components that we can monitor to gage progress toward the recovery of ecosystem integrity.

\section{Habitat, Goals, Objectives, and Strategies}

Much of Palmyra Atoll is a national wildlife refuge, and the development of a comprehensive conservation plan (CCP) is currently underway. The goals and objectives developed and strategies to achieve them, as will be identified within this CCP, will ultimately serve as the guidance for operations at Palmyra Atoll National Wildlife Refuge. This "Terrestrial Forest Management Plan for Palmyra Atoll" may provide preliminary operational guidelines for TNC and serve as part of their effort in contributing toward the development of the Palmyra Atoll National Wildlife Refuge CCP. Finally, this plan with approval and collaboration could be used in the interim as a guide for TNC and the FWS management actions. Priority management goals and objectives were identified for this plan in collaboration with TNC (Palmyra Program director and deputy director) and the FWS (refuge manager) in 2008. Collective knowledge of the status of Palmyra Atoll terrestrial resources was considered over varying temporal and spatial scales of management issues while considering national wildlife refuge legal mandates. Input from literature review and discussions with numerous research scientists have all been incorporated into defining the specific objectives and strategies for focused action discussed within this plan.

Palmyra Atoll represents a unique opportunity to advance our understanding of ecosystem science through adaptive management, monitoring, and research. Ideally, management, monitoring, and research will work hand-in-hand to improve decisions for protecting, conserving, and where possible restoring the biodiversity, biological integrity, and environmental health within the ecosystem. Any long-term management and monitoring program must begin with establishing baseline information to assess changes in ecosystem status over time and evaluate what management action may be necessary and the impacts and success of management. Over time more intensive research projects can focus on key uncertainties in the system to provide the necessary resolution for further management.

The most urgent issues concerning the Palmyra terrestrial ecosystem are nonnative invasive species. This "Terrestrial Forest Management Plan for Palmyra Atoll” addresses issues related to invasive species and other problems. Priority goals are established along with associated objectives and strategies. The overarching goal is to perpetuate and where possible restore terrestrial ecosystem integrity through the following techniques: 
1. Habitat Management: Maintain and enhance habitat to the extent possible to sustain thriving Pisonia grandis forest, coastal strand forest, endemic grassland, and self-sustaining populations of sea birds and shore birds, coconut crabs, native lizards, and native insects.

2. Monitoring and Assessment: Acquire information on distribution and abundance as needed for conservation of each resource of concern by developing monitoring and assessment programs relevant to local, regional, and national needs.

3. Research: Gather new information to facilitate conservation of terrestrial forest resources. This information will pertain to the ecology of the terrestrial ecosystem.

4. Planning: Achieve regional cooperation for conservation by developing a process to facilitate planning among relevant agencies and by working toward integration of resource concerns with land management plans at local to global levels.

The aim of developing the goals, objectives, and strategies within this "Terrestrial Forest Management Plan for Palmyra Atoll" is to carry out on-the-ground conservation and management activities. The strategies drafted here focus on population enhancement through maintenance and improvement of key ecosystem components. The general desired outcome is to protect and maintain all native ecosystems and the biological diversity of Palmyra Atoll and conserve all constituent native species with an emphasis on sea bird populations. This desire resulted in a single goal with multiple objectives: Habitat Goal 1 (HG1): Protect, maintain, and where possible restore terrestrial ecosystem integrity - the natural biological communities and their associated biodiversity, habitats, populations, ecological processes, and environmental health of Palmyra Atoll. This goal and related objectives and strategies to achieve these are described in the following section. 


\section{Goals and Objectives of the "Terrestrial Forest Management Plan for Palmyra Atoll"}

Habitat Goal 1 (HG1) Protect, maintain, and where possible restore terrestrial ecosystem integrity - the natural biological communities and their associated biodiversity, habitats, populations, ecological processes, and environmental health of Palmyra Atoll.

To assist in achieving this goal, several major objectives have been identified and are listed below in no particular order.

Objective 1 (HG1-O1): Develop conceptual model(s).

Objective 2 (HG1-O2): Map historical islet boundaries.

Objective 3 (HG1-O3): Measure, classify, and map terrestrial vegetation.

Objective 4 (HG1-O4): Measure, classify, and map soils.

Objective 5 (HG1-O5): Measure, classify, and map groundwater.

Objective 6 (HG1-06): Maintain existing Pisonia grandis stands and promote new growth and expansion.

(HG1-O6a): Maintain large trees in Pisonia grandis stands that incurred extensive large-tree mortality during 2001-6.

(HG1-O6b): Promote regeneration of small trees in Pisonia grandis stands that incurred moderate mortality during 2001-6.

(HG1-O6c): Implement a "no net loss" Pisonia grandis strategy.

Objective 7 (HG1-O7): Control coconut palm succession and incursion into Pisonia grandis stands that suffered moderate to extensive mortality during the scale infestation. Objective 8 (HG1-O8): Create openings for native coastal shrubs to colonize monotypic stands of coconut palm.

Objective 9 (HG1-O9): Map contaminants.

Objective 10 (HG1-O10): Remediate contaminants in priority areas.

Objective 11 (HG1-O11): Evaluate potential short- and long-term impacts of climate change.

Objective 12 (HG1-O12): Maintain and increase genetic diversity.

Objective 13 (HG1-O13): Accelerate native forest restoration.

Objective 14 (HG1-O14): Reintroduce former native faunal species extirpated from

Palmyra Atoll. 


\section{Management Goals, Objectives, and Strategies for the Palmyra Atoll Terrestrial Forest}

Habitat Goal 1 (HG1): Protect, maintain, and where possible restore terrestrial ecosystem integrity - the natural biological communities and their associated biodiversity, habitats, populations, ecological processes, and environmental health of Palmyra Atoll.

\section{Range of Natural Variation}

A terrestrial ecosystem that falls within the range of natural variability will have spatial patterns consistent with the processes associated with ecological types, diverse habitat to maintain natural communities, and viable populations of the floral and faunal species native to the region. For every ecosystem, natural disturbance processes are driven by variables with measurable patterns of frequency, intensity, and spatial scale. These patterns of variability over time constitute the range of natural variation. Within the range of natural variation, healthy ecosystems absorb and recover from disturbances without drastic alteration of their inherent function. Range of variability here refers to the area in which plant and animal communities can naturally live and reproduce, referring to potential as opposed to current distributions. Natural communities are assemblages of plants and animals, fungi, and microorganisms associated with each other; their physical environments; and natural processes within a given area. Viable populations maintain sufficient size to persist over time despite natural stochastic processes. Ideally, terrestrial ecosystems maintain the given forest successional trajectories despite stressors. The physical environment should be capable of sustaining reproducing populations of priority tree species, necessary for continued forest stability and development, which in turn provide habitat capable of sustaining reproducing populations of priority wildlife species. This plan aims to ensure ecosystem integrity and stability by managing for an ecosystem's capacity for resistance and resilience. Many factors, including large storm events, play a role in natural disturbance processes and fall within the range of natural variation; however, other factors, including military modification and the introduction of invasive insects, may alter ecosystem structure and historical energy-flow pathways. Such factors could inhibit the ecosystem from returning to the desired equilibrium and cause it to depart even further from the desired future state.

\section{Desired Future Conditions}

The attributes of a restored ecosystem from the Society for Ecological Restoration International Science and Policy Working Group (2004) provide standards to measure success. These standards, modified as relevant to Palmyra Atoll, are listed below.

- The ecosystem contains a characteristic assemblage of indigenous plant and animal species that provides for a natural/historical community structure (for example, conserve sea bird populations and habitats). Restore conditions in which refuge ecosystems are fully capable of sustaining normal ecosystem functions and display or mimic all or in part the floral and faunal biodiversity and community structure that occurred before military modification. All functional groups of the ecosystem are represented or have the potential to colonize by natural means.

- Restore environmental health such that the physical environment supports and sustains reproducing populations of species essential for ecosystem stability and (or) development along the desired trajectory. 
- Maintain and reinstate forest conditions in which the dynamic attributes that compose refuge ecosystems are expressed within "normal" ranges of variability and activity relative to their ecological stage of development, and signs of dysfunction are absent. The terrestrial ecosystem is resilient to normal periodic stress events. The forest ecosystem is suitably integrated into the landscape through abiotic and biotic flows and exchanges.

- Threats to restored habitat integrity are reduced or eliminated, and management opportunities are identified to deter vegetative phaseshifts and trophic cascades associated with invasive species and human-caused influences.

The FWS envisions a terrestrial ecosystem that is managed in parallel with other atoll management and restoration efforts. Late-seral "old growth" Pisonia grandis forest will predominate many of the areas where natural islets once occurred. In these "natural" areas, a highly resilient and steady-state native coastal strand community of beach naupaka and tree heliotrope will occupy many of the coastal edges, gaining only occasional footholds into the interior Pisonia grandis stands. Altered coconut palm succession and dominance will be curtailed beginning within areas where storms and heavy insect-related disturbance caused mortality of mature Pisonia grandis and where native coastal strand forest species are inhibited from establishing along coastal niches because of coconut palm monocultures.

- Management can sustain and restore biological diversity by promoting habitat structure and composition within its historical bounds. Restoration of biological diversity may confer resilience to natural disturbances within the historical range of natural variability. Whether the restored system will be resilient to disturbance outside this range remains to be seen. Our expectation is that a restored system has the best chance of resilience to novel changes as well.

For each objective toward the goal of protecting, maintaining, and where possible restoring terrestrial ecosystem integrity, monitoring "objectives" must be incorporated. Adaptive management should take place such that management actions are set in the context of well-designed monitoring programs. Monitoring that is designed to show the effectiveness of management actions should be built into the "Terrestrial Forest Management Plan for Palmyra Atoll". Monitoring results should be reviewed annually to provide feedback to management so that treatments can be adjusted if necessary to move toward achieving the target condition. A list of guidelines/objectives for monitoring the terrestrial ecosystem of Palmyra Atoll follows:

1. Balance traditional species-specific and site-specific inventory and monitoring efforts with collection of data in a broader, community-based, ecosystem context.

a. Identify significant gaps in the science available to support an ecosystem monitoring approach.

b. Anticipate the need for solutions to subtle and far-reaching problems in the future of cumulative and interactive ecological effects.

2. Ensure that an adaptive management strategy is incorporated into monitoring, monitoring studies, and research to assess and modify management strategies to achieve habitat objectives. 
3. Promote the use of coordinated, standardized, cost-effective, scale-dependant, statistically sound and defensible sampling designs and methods for gathering, analyzing, and presenting qualitative and quantitative data.
a. Identify and prioritize baseline status monitoring and effectiveness monitoring, as well as monitoring studies for each management strategy and alternative.
b. Identify research objectives that address key management questions or uncertainties.

Management actions are suggested that will affect different ecosystem components directly and indirectly and could produce unexpected results. For example, based on previous monitoring some suggested management actions are intended to promote native forest expansion and maintain and increase forest integrity. Monitoring design is an integral part of the planning and implementation of these actions. For instance, to document trends in forest stand composition, native plant recruitment, and habitat structure (for native animals of concern) with time since management action (for example, coconut palm control, rat removal, other nonnative or invasive removal), baseline data must be collected within a monitoring design context. Baseline data collection is the first step in implementing monitoring, and it can be used to learn more about distribution and habitat requirements. Baseline data are also essential in determining species status and in monitoring to assess management effects. This step should not be overlooked in the initial development and implementation of management strategies.

\section{Objectives}

\section{(HG1-01) Develop conceptual model(s).}

Develop new and refine existing conceptual model(s) outlining ecosystem interconnections, including ecosystem drivers; ecological stressors; the biological, physical, and chemical processes that are affected by these stressors; ecosystem values; and measurable attributes to evaluate the status of ecosystem values.

\section{$\underline{\text { Rationale }}$}

Conceptual models provide a vehicle for discussion and facilitate the process of summarizing existing knowledge and making hypotheses about the components of a system and their interactions. They assist in identifying resources of concern and their limiting factors. In turn, they assist in the identification of potential management and monitoring objectives, help identify critical assumptions and uncertainties remaining to be resolved, and may help determine what management actions may be most appropriate and effective for achieving management goals. Multiple models can be developed and modified as necessary (for example, to portray hierarchically nested models representing different levels of complexity within the ecosystem at varying spatial and temporal scales), as well as to overcome the disadvantages of any one model type.

\section{$\underline{\text { Strategy }}$}

- Create and refine driver-stressor model(s), state and transition model(s), and control model(s).

- Conceptual modeling begins with identifying the goal of the model. Models should communicate general ecosystem characteristics and our understanding of system dynamics. For a driver-stressor model this leads to steps such as identifying and understanding drivers in the ecosystem. Drivers are sources of change that may be physical, biological, or chemical and may include natural (for example, storms) and human-caused (for example, introduced species) 
processes, while stressors are physical or chemical changes that can result from drivers and can create changes in abiotic and biotic components of the system. Models can include ecological interactions between drivers that in turn result in changes (abiotic and biotic), all of which may influence the condition, structure, integrity, stability, distribution, trajectory, and succession of in this case Pisonia grandis and other plant communities within the terrestrial forest ecosystem. Likewise, these factors are related back to the faunal components of the system, and all components feed back to ecosystem processes such as nutrient cycling and trophic relations. It is essential to evaluate the importance of ecosystem drivers and how they might be influenced to minimize any negative ecosystem impacts.

- State-transition models can be used as a management tool illustrating hypotheses about how transitions may occur between states. An example of this is the highly simplified model for transitions between vegetation types shown in fig. 2 in response to disturbance such as from invasive species or management action to remove invasive species.

- Control models can be used to evaluate process feedback and mechanisms. For example, a control model can be used to summarize the current understanding of feedback and mechanisms that exist between many components: plant communities, nutrients, consumers, decomposers, humus, and water availability and may include how drivers such as climate change or invasive species may affect the system as well as how these all interlink.

\section{(HG1-O2) Map historical islet boundaries.}

Use historical maps (for example, Collen and others, 2009) to produce a map of islet boundaries for the period before military modification.

\section{$\underline{\text { Rationale }}$}

The military scraped islets and used dredge material to connect existing islets. Military personnel also created causeways for increased movement, as well as 10 additional islets of varying sizes, 6 of which still exist. These military modifications have had large effects on the Palmyra Atoll ecosystems including the following:

- changes in land area (doubled), volume (tripled), and connectivity.

- changes in substrate.

- changes in surface elevation.

- changes in groundwater.

- changes in lagoon flow dynamics.

- changes in species distribution and potentially species composition.

The impacts of these changes to the terrestrial ecosystem are largely unknown, and identifying original boundaries can be used to assess at least some of the potential effects. In addition, there have been reports that the increased connectivity between islets has negatively impacted lagoon flow and sedimentation (Dawson, 1959; Maragos, 1993). There is evidence that ecosystem processes appear to be reverting Palmyra Atoll islets back to their natural boundaries, a factor which is important in prioritizing restoration sites (Collen and others, 2009). Finally, future management actions attempting to facilitate reversal of military modifications will undoubtedly have impacts to the current state of the terrestrial ecosystem. 


\section{$\underline{\text { Strategy }}$}

- Collaborate with University of Victoria scientists (see Collen and others, 2009) to compare historical islet configuration data (converted to Geographic Information System [GIS]) to current boundaries.

\section{(HG1-03) Measure, classify, and map terrestrial vegetation.}

Spatially quantify current terrestrial vegetation (for example, Pisonia grandis forest extent, distribution, state, size class, succession) and the deviation of current terrestrial forest habitats from 2001-2 (early scale outbreak) conditions. Update or replace Wegmann (2005) vegetation maps by using classification with remotely sensed data and repeat Nonner and Woodward (2006) Pisonia grandis size-class inventory. Consider paleoecology to identify currently unrepresented species.

\section{$\underline{\text { Rationale }}$}

Developing terrestrial vegetation data within a GIS framework will be important in establishing priorities for habitat management goals and objectives, identifying restoration or remediation strategies, developing monitoring and research plans, and prioritizing projects. These data may include identification of where and to what extent changes have occurred and correlation with other variables to make hypotheses about the causes of vegetation changes, potential problems, evaluating succession, nonnative species distribution, canopy cover, and so on.

\section{$\underline{\text { Strategy }}$}

Design and conduct forest surveys consistent with long-term monitoring. Examine the range of variation in current plant species abundance, community composition and structure, plant diversity, litter, and substrate cover. (Some of the major vegetation types include stands dominated by coconut palm, Pisonia grandis, beach naupaka, tree heliotrope, tropical almond, hau, Pandanus fischerianus, Phymatosorus scolopendria, and Lepturus repens.)

- Relate environmental factors (for example, hydrology, soil type and components, land use, proximity to strand, proximity to landing points) to major plant communities mapped by Wegmann (2005) and described by Freeman (2006a).

- Describe locations and map distribution of rare and sensitive plants (beginning with Depkin, 2002, and Freeman, 2006a, b).

- Conduct vegetation classification and mapping.

- Conduct spatial analyses. Vegetation maps can be combined with maps of other biotic and abiotic resources making them useful tools for understanding interactions. Combining different maps can reveal correlations and underlying relations. They can be evaluated spatially and temporally for patterns and trends in native and nonnative species distributions. This information can be used to track and study spatially explicit effects of natural disturbances, management actions, and resource changes over time and make predictions about changes in the future.

\section{(HG1-04) Measure, classify, and map soils.} fauna use.

Spatially quantify soil properties and patterns relative to vegetation associations and terrestrial 


\section{$\underline{\text { Rationale }}$}

Developing soil data within a GIS framework and characterizing variables related to ecosystem processes such as physical and chemical properties (for example, soil moisture, depth, nutrients) will be important in establishing priorities for habitat management goals and objectives, identification of restoration or remediation strategies, developing monitoring and research plans, and prioritization of projects. Some potential management issues include soil quality for soil fauna and terrestrial plants and potential competition for soil nutrients between coconut palms and other plants. Understanding variability is necessary in determining the response of the soil resources to management actions, specifically the removal of coconut palms, increasing forest diversity, and restoration of lagoon circulation.

\section{Strategy}

- Prior to beginning relevant restoration activities, assess the best techniques for conducting surveys to determine baseline soil conditions and parameters of interest.

- Conduct soil classification and mapping.

- Correlate soil properties with resources of concern to investigate underlying relations and prioritize potential restoration sites.

- Conduct toxicity studies of the soil to assess contaminant levels, as various chemicals might interact with or inhibit restoration goals.

\section{(HG1-05) Measure, classify, and map groundwater.}

Spatially quantify groundwater properties relative to vegetation associations and terrestrial fauna use.

$\underline{\text { Rationale }}$

Developing groundwater data within a GIS framework will be important in establishing priorities for habitat management goals and objectives, identification of restoration or remediation strategies, developing monitoring and research plans, and prioritization of projects. Some potential management issues include groundwater availability to terrestrial plants, groundwater quality, and potential competition for groundwater between coconut palms and other plants, particularly native seedlings trying to establish. Understanding groundwater variability is necessary in determining the response of the groundwater resources to management actions, specifically the removal of coconut palms, increasing forest diversity, and restoration of lagoon circulation.

\section{Strategy}

- Prior to beginning relevant restoration activities, assess the best techniques for conducting surveys to determine baseline groundwater conditions. Various tools exist to determine groundwater extent on atolls. These tools include monitoring wells, seismic profiling, and fiberoptic distributed temperature sensing (Ward, 1990). Long-term monitoring could be achieved through remote monitoring across seasons to determine the effect of rainfall on the depth and extent of freshwater lenses.

- Conduct toxicity studies of the groundwater to assess contaminant levels, as various chemicals might interact with or inhibit restoration goals.

- Determine the location, extent, and quantity of the groundwater resources on Palmyra Atoll, if present. Identify the vertical and lateral extent of any fresh groundwater lens. 
- Assess the groundwater quality in relation to maximum salinity for biotic use and human-caused contamination.

- Determine the age of groundwater and the basic hydrology of Palmyra Atoll.

- Install groundwater monitoring stations on multiple islets (for example, disturbed, natural, and humanmade) to record and log water quantity and quality for a hydrologic model.

\section{(HG1-06) Maintain existing Pisonia grandis stands and promote new growth and expansion.}

\section{(HG1-O6a) Maintain large trees in Pisonia grandis stands that incurred extensive large-tree mortality during 2001-6.}

Ensure that Pisonia grandis stands lose no more than 15 percent of their largest diameter trees and no more than 10 percent of their mid-diameter trees to scale outbreaks over the next 20 years.

\section{(HG1-O6b) Promote regeneration of small trees in Pisonia grandis stands that incurred moderate mortality during 2001-6.}

Ensure establishment of small trees within stands in or near gaps created by the death of large canopy trees.

\section{(HG1-O6c) Implement a "no net loss" Pisonia grandis strategy.}

Maintain or restore Pisonia grandis so that the numbers of stands and numbers of individuals atoll-wide are equal to levels documented in the FWS early scale outbreak monitoring beginning in 2004 (Nonner and Woodward, 2006).

\section{$\underline{\text { Rationale }}$}

To ensure that Pisonia grandis stands persist into perpetuity, it is important to protect and where possible restore not only mature stands but also stands with a high percentage of smaller diameter trees that can grow into canopy gaps when they are created. Therefore, to ensure that late-seral stage stands continue to exist, it is important to maintain larger trees until they can be replaced over time. "No net loss" here means protecting not only mature trees but also younger stands and smaller diameter trees within the forest. This protection will allow younger trees to mature and replace larger diameter trees in the future. Pisonia grandis stands have often been described as monotypic; managing stands that largely consist of Pisonia grandis by number and cover facilitates natural succession back to this original state. Understanding the species composition, diameter distribution, and other species information allows us to develop a comprehensive strategic management plan to meet this objective. Various diameter trees are important for the health and longevity of the forest and provide a diversity of functions and structures for use by forest constituents.

\section{$\underline{\text { Strategy }}$}

- In the absence of detailed historical stand information, use existing maps of vegetation types (Wegmann, 2005) and initial Pisonia grandis census information (Nonner and Woodward, 2006) to determine baseline conditions.

- Identify priority areas for management and restoration.

- Coconut palm control-Develop and implement a program to reduce cover/density of coconut palms (see app. 1) (a) on islets where there are mixed stands of coconut palm and Pisonia grandis and (b) where coconut palms are present as monotypic stands. 
- Plant Pisonia grandis seedlings, saplings, or cuttings and encourage growth of existing Pisonia grandis in coconut palm control areas.

- Encourage Pisonia grandis growth in canopy gaps created by falling Pisonia grandis trees.

- Develop and implement a program to prevent coconut palm spread to islets without coconut palms after removal efforts.

- Evaluate conditions across sites, comparing stand health with site parameters to assess potential problems such as nutrient deficiencies and potential ectomycorrhizal requirements (that is, determine presence and distribution to assess areas possibly lacking or containing a paucity of mycobionts).

- Evaluate effectiveness of recent Pisonia grandis management strategies at Palmyra Atoll and elsewhere (that is, imidicloprid injection, biocontrol using Cryptolaemus montrouzieri coupled with ant control) aimed at removing scale infestations to prevent further spread and increase forest health.

- Develop collaborations globally to share and develop management, monitoring, and research protocols and results and develop alerts for early warning signs.

\section{$\underline{\text { Uncertainties }}$}

We do not know what size Pisonia grandis trees made up the various seral stages at pre-scaleinfestation locations or the natural variation in abundance over time. Likewise we do not know the prevalence of other native species in mixed stands dominated by Pisonia grandis. The natural ability of forests to restore themselves is unclear, and management actions may be necessary (for example, determine whether nutrient deficiency is a problem and if it can be solved by fertilizer application; determine if ectomycorrhizae are an integral part of forest health at Palmyra Atoll and if they are present in sufficient numbers at restoration sites or should be harvested from other sites and added to soil). If active restoration is determined necessary, examine the best means to propagate and outplant native plants and trees, determine whether genetic consideration is necessary, identify priority locations for forest restoration, actively propagate and outplant native plants, apply soil amendments where necessary, and monitor success.

\section{(HG1-07) Control coconut palm succession and incursion into Pisonia grandis stands that have suffered moderate to extensive mortality during the scale infestation.}

Reduce coconut palms to 0 percent cover within $50 \mathrm{~m}$ of the peripheral edge of all mid-seral and late-seral Pisonia grandis stands. Also, remove all coconut palms from existing gaps and eliminate them as they occur in new gaps.

\section{$\underline{\text { Rationale }}$}

The general consensus seems to be that coconut palms have the capacity to invade Palmyra Atoll forests, changing nutrient cycling processes and water regimes and altering habitats for animals. There are multiple documented plantings of these trees (Rock, 1916; Dawson, 1959), and their numbers have increased from several thousand to about two million since first documented. Palmyra Atoll scientists observe that the coconut palm may have a competitive advantage over Pisonia grandis through competition for water, direct and indirect alteration of soil nutrients, physical damage from nut and frond fall, and shading. There is much discussion in the Palmyra Atoll files and literature about the role of coconut palms in island ecology (Young and others 2010a, b).

Coconut palm saplings are currently evident in almost every Pisonia grandis gap. They are generally taller than the Pisonia grandis specimens even when they are the same age. Therefore, 
coconut palms may be able to recolonize the Pisonia grandis tree-fall gaps, establishing a presence in the island interior where they were scarce before tree-fall. A prudent management action may involve eradicating coconut palms in the gaps as soon as possible, and preferably before they become reproductive.

\section{Strategy}

- Coconut palm control (see app. 1).

\section{(HG1-08) Create openings for native coastal shrubs to colonize monotypic coconut palm stands.}

Manage for native closed-canopy tree heliotrope and beach naupaka shrubs by reducing the current linear extent of coastal monotypic coconut palm stands (greater than 90 percent coconut palm cover for greater than $300 \mathrm{~m}$ along the coast) to 10 percent coconut palms by cover every other $100 \mathrm{~m}$ along the coast and $50 \mathrm{~m}$ from water within the next 3 years.

\section{$\underline{\text { Rationale }}$}

Native coastal shrub species are halophytic pioneers and though still widespread across their native range are not as abundant as they once were. Coastal strand species can play a role in reducing erosion, contributing to soil development and succession, and protecting other native species such as Pisonia grandis from salt spray and wind throw, as well as providing habitat for various native vertebrate and invertebrate species. Tree heliotrope is a preferred roosting and nesting species for sea birds. To ensure that native coastal shrub stands persist, it is important to not only protect and where possible restore existing stands but also increase their extent by reducing the areas taken over by coconut palms.

\section{$\underline{\text { Strategy }}$}

- Coconut palm control-Develop and implement a program to reduce cover/density of coconut palms (see app. 1) (a) on islets where there are mixed stands of coconut palms and other trees and (b) where coconut palms are present as monotypic stands.

- Develop and implement a program to prevent coconut palm spread to islets without coconut palms after removal efforts.

\section{(HG1-09) Map contaminants.}

Spatially quantify contaminants on Palmyra Atoll.

\section{$\underline{\text { Rationale }}$}

After Palmyra Atoll was declared a Formerly Used Defense Site (R.M. Towill Corporation, 1993; Woodward, 2001) in 1992, investigation, planning, and remediation activities to locate, evaluate, and remove debris and contaminated materials occurred through 1998. Sites requiring remediation still remain, however, and these sites as well as additional sites should be investigated for potentially negative ecological effects. In addition, developing contaminant data within a GIS framework will be important in establishing priorities for habitat management goals and objectives, identification of restoration or remediation strategies, developing monitoring and research plans, and prioritization of projects. This information will aid in the conservation of resources on Palmyra Atoll by preventing or minimizing health effects due to exposure to Palmyra Atoll's legacy contaminants 
In addition there are newly arriving contaminants such as those from marine debris and the potential for accidental spills from terrestrial and offshore activities. Marine debris not only can be mechanically detrimental because of entanglement or internal damage from ingesting but also can harbor contaminants that can poison the organisms ingesting them.

\section{Strategy}

- Continue surveys for contamination sources and develop a digitally geocoded GIS map of the known (potential) sources of contamination (KPSOCs) on Palmyra Atoll. Provide specific information on the location, type, and description of the KPSOCs.

- Evaluate the ecological impacts of persistent and newly arriving contaminants.

\section{(HG1-010) Remediate contaminants in priority areas.}

$\underline{\text { Rationale }}$

See rationale for HG1-O9.

$\underline{\text { Strategy }}$

- Develop protocols for regularly collecting and appropriately disposing of marine debris.

- Other remediation activities will be developed on the basis of findings from HG1-O9.

\section{(HG1-011) Evaluate potential short- and long-term impacts of climate change.}

The impacts of climate change with regard to terrestrial habitats may include increased frequency and intensity of storms, and sea level rise that results in changing temperature and precipitation patterns, saltwater intrusion of groundwater, and outright inundation. Expected biological effects include significant changes to species distributions and ecosystem functions and increases in the range and impact of many forest invasive species and diseases.

\section{$\underline{\text { Rationale }}$}

Climate change has proximate and long-term effects on natural resources. Storms and droughts and temperature changes have the potential for direct and indirect negative effects. Gathering information regarding changes over time will be important for determining trend data locally. These data could also act as a bellwether for nearby regions and internationally to develop response strategies to reduce potentially negative impacts where possible.

\section{Strategy}

- Identify appropriate weather monitoring stations; determine how many monitoring stations are necessary and where to deploy them. Set up a system for maintenance of the stations, as well as the data collection, processing, and dissemination.

- Complete literature reviews for the design and development of a monitoring plan that integrates changes in weather with changes in other aspects of the system.

\section{(HG1-012) Maintain and increase genetic diversity.} ecosystem.

Recognize and preserve the genetic variability of species associated with the terrestrial 


\section{$\underline{\text { Rationale }}$}

Just as it is important to protect and restore nutrient cycling and other ecosystem processes, maintaining and where necessary restoring evolutionary processes are integral to the long-term viability of ecosystems. Genetic variability can increase species ability to withstand short-term abiotic and biotic disturbances such as outbreaks of pathogens and provides the potential for adaptive evolution in the face of longer term changes in the ecosystem such as that expected with climate change.

\section{$\underline{\text { Strategy }}$}

- Identify genetic diversity at Palmyra Atoll and frame relations according to global diversity.

- Evaluate practices that affect gene pools and biodiversity (for example, seed sources for reforestation).

- Once a genetic framework is identified, set goals for maintaining or increasing genetic diversity.

\section{(HG1-013) Accelerate native forest restoration.}

\section{$\underline{\text { Rationale }}$}

Pisonia grandis was once considered common on coral islands but has recently undergone considerable heavy disturbance from activities such as military use, phosphate mining, attempts to establish copra plantations, and invasive species introductions. It has been described as declining within its native range (Walker, 1991). While the above mentioned activities have ceased (with the exception of unintentional invasive species introductions), coconut palms have reached invasive species status and continue to proliferate, and rats consume seedlings and consume and disperse seeds where they will not germinate.

Pisonia grandis and coastal strand forests not only are important in and of themselves but also are used by many faunal resources of concern, including sea birds, geckos, crabs, and other invertebrates. Sea birds, specifically tree nesters, use native forest as primary habitat for resting and breeding. Generally, they prefer Pisonia grandis and tree heliotrope. Crabs use the forest floor and largely avoid open areas. They forage on live and dead plant matter, seeds, seedlings, and decomposing plants and animals and use the cover for hiding. Native geckos are found on forest plants (with most data currently from forest margins and not a lot of information yet available from the forest interior). Current examinations of trophic structure are beginning to reveal important patterns indicating differences in food resources used by geckos in native forest versus coconut palm forests. Stomach content analyses are in progress (H. Young, Stanford University; R. Fisher, U.S. Geological Survey, oral commun., 2008). Additional insect surveys are planned (H. Young, Stanford University, oral commun., 2008). Combining these and additional surveys, as well as continued isotope work, will be beneficial in identifying important habitat and resources.

\section{Strategy}

- Eradicate rats-Develop and approve study designs, monitoring programs, and implementation strategies.

- Coconut palm control-Develop and implement a program to reduce cover/density of coconut palms (see app. 1).

- Identify locations for forest restoration.

- Evaluate conditions across sites by comparing stand health with site parameters to assess potential problems such as nutrient deficiencies and potential ectomycorrhizal requirements (that is, determine presence and distribution to assess areas potentially lacking or containing a paucity of mycobionts). 
- Evaluate effectiveness of recent Pisonia grandis management strategies at Palmyra Atoll and elsewhere (that is, imidicloprid injection, biocontrol using Cryptolaemus montrouzieri coupled with ant control) aimed at removing scale infestations to prevent further spread and increase forest health.

- Actively propagate and outplant native plants.

- Develop collaborations globally to share and develop management, monitoring, and research protocols and results and develop alerts for early warning signs.

\section{Uncertainties}

There is a general need to determine the best means to propagate and outplant native plants and trees (for example, transplants, seeds, cuttings, fertilizer, caging, ectomycorrhizal enhancement) and to determine whether genetically diverse plant stock is necessary.

\section{(HG1-014) Reintroduce former native fauna species extirpated from Palmyra Atoll.}

\section{Rationale}

The terrestrial forest ecosystem may have once supported additional species that have been extirpated because of disturbance from activities such as military use, attempts to establish copra plantations, and invasive species introductions. Many of these locally extirpated species played an important role in ecosystem processes and are in decline in other parts of their range. Successful implementation of this objective requires initial management action, such as rat eradication, to eliminate threats to former native species.

\section{$\underline{\text { Strategy }}$}

- Eradicate rats-Develop and approve study designs, monitoring programs, and implementation strategies.

- Develop plans to attract or translocate species identified as extirpated (for example, shearwater and petrel species could be attracted with call playback).

\section{Scope and Limitations of this "Terrestrial Forest Management Plan for Palmyra Atoll"}

There are limitations to the scope of the "Terrestrial Forest Management Plan for Palmyra Atoll". As mentioned above, this plan is not yet meant to be comprehensive. Additional literature review will undoubtedly uncover more information specific or relevant to management activities on Palmyra Atoll, and it should be recognized that this plan is still in the development process. As stated, the focus of this plan is to strategize on how to meet mutual goals of TNC and the FWS to conserve and protect resources. This plan was written in an attempt to be realistic about where research and management efforts should be initially focused and is not meant to indicate that other aspects are unimportant. Instead, this "Terrestrial Forest Management Plan for Palmyra Atoll" is an effort to tackle the highest priorities first. There is still a need to expand the current objectives and strategies and potentially even modify goals as deemed necessary through additional expert review. As such, this document will benefit from an adaptive management approach to subsequent updates to the plan, as efforts planned for the near term are refined and implemented. 
Some of the key questions and recommendations associated with management actions are listed below.

1. Will forest management actions reverse past human-caused problems? To what degree and at what cost?

2. Will anticipated patterns and diversity of forest seral stages be resilient to the interaction of changing climate, insects, and disease in the long term?

3 . How will the terrestrial forest ecosystem respond to coconut palm control?

4. Vegetation dynamics will change, and development of the plant monitoring design will be important.

5. How will the terrestrial forest ecosystem respond to black rat eradication?

6. Sea bird and shore bird populations may increase with management actions to improve Pisonia grandis forest (specifically, removing coconut palms and eradicating rats). It is recommended that researchers review Citta and others (2006) for monitoring guidance. Alternatively, sea bird and shore bird populations may not increase despite onsite terrestrial management actions. Sea birds forage offshore, and shore birds migrate from distant breeding sites. Concurrently developing collaborations toward monitoring and managing pressures outside the proximate terrestrial ecosystem will be necessary to successfully protect the birds utilizing and contributing to Palmyra Atoll terrestrial ecosystem integrity.

7. Other faunal communities may increase over the short or long term with management actions to improve Pisonia grandis forest by removing coconut palms and eradicating rats. Monitoring plans have been under development, and some have already begun implementation (for example, H. Young, Stanford University; A. Wegmann, University of Hawai 'i; J. Collen, Victoria University of Wellington, oral commun., 2008; E. Sterling, American Museum of Natural History; R. Fisher, S. Hathaway, K. McEachern, D. Papoulias and K. Hart, U.S. Geological Survey, and others). This information can inform planned management actions as well as assess impacts. It is recommended that researchers continue monitoring plan development and baseline data collection. 


\section{Potential Workplan}

\section{Phase 1}

General

- Build teams relevant to the review, development, and implementation of monitoring and management planning.

- Continue drafting management planning documents.

- Continue drafting conceptual models.

- Continue developing strategies for objectives.

- Continue developing and implementing monitoring plans.

- Build data quality assurance, data management, analysis, and reporting strategies.

- Develop adaptive management feedback loop process.

- Implement approved pieces of plan.

\section{Examples}

- Experimentally reduce/remove invasive and (or) competing species. For example, begin coconut palm control and management. Monitor for expected and unexpected ecosystem responses to threats and management prior to and subsequent to implementing management action.

- Continue efforts to design and implement rat eradication, including developing monitoring plans and collecting baseline information.

- Inventory resources and identify and model relations:

- What is the distribution and status of Pisonia grandis forest across Palmyra Atoll?

- What is the range of variation within the terrestrial ecosystem?

- With what specific habitat parameters are Pisonia grandis forest and other vegetation types associated (for example, soil quality, moisture availability, and so on)?

- What are the extent, distribution, and condition of those habitats?

- To what pressures is Pisonia grandis sensitive?

- What are the distribution, abundance, and habitat characteristics and trophic interactions of native sea birds? Geckos? Crabs? Insects? 


\section{Phase 2}

General

- Review Phase 1 and adapt as necessary.

Examples

Status and trends questions:

- Document trends in forest stand composition, native plant recruitment with time since coconut palm removal (repeat for rat removal).

- Is the abundance of Pisonia grandis on Palmyra Atoll within baseline range of variation? If not, is it increasing or decreasing?

- Formulate questions to identify early warning of problems: Is the areal extent of Pisonia grandis changing?

- What is the abundance or proportion of trees harboring scale - a pest considered to severely reduce tree health and potentially cause tree mortality?

- Targeted study questions: Which habitat restoration techniques result in a Pisonia grandis forest recovery success rate at or above a level sufficient to sustain populations?

- Continue implementation of rat eradication.

- Continue coconut palm control. 


\section{References Cited}

Airy Shaw, H.K., 1952, On the distribution of Pisonia grandis R. Br. (Nyctaginaceae) with special reference to Malaysia: Kew Bulletin, v. 7, no. 1, p. 87-97.

Allaway, W.G., and Ashford, A.E., 1984, Nutrient input by seabirds to the forest on a coral island of the Great Barrier Reef: Marine Ecology - Progress Series, v. 19, no. 3, p. 297-298.

Aronson, Karen, and Anderson, Lisa, 2000, Archaeological monitoring of remedial action, Palmyra Atoll: Prepared by Ogden Environmental and Energy Services Co., Inc., 82 p.

Ashford, A.E., and Allaway, W.G., 1985, Transfer cells and hartig net in the root epidermis of the sheathing mycorrhiza of Pisonia grandis R. Br. from Seychelles: New Phytologist, v. 100, no. 4, p. 595-612.

Atkinson, Andrea, Trenham, P.C., Fisher, R.N., Hathaway, S.A., Johnson, B.S., Torres, S.G., and Moore, Y.C., 2004, Designing monitoring programs in an adaptive management context for regional multiple species conservation plans: Sacramento, Calif., U.S. Geological Survey Western Ecological Research Center, U.S. Geological Survey Technical Report, 69 p.

Ayers, J.F., and Vacher, J.W., 1986, Hydrogeology of an atoll island - a conceptual model from detailed study of a Micronesian example: Ground Water, v. 24, no. 2, p. 185-198.

Bailey, R.T., Jenson, J.W., and Olsen, A.E., 2009, Numerical modeling of atoll island hydrogeology: Ground Water, v. 47, no. 2, p. 184-196.

Bell, H.L., 1969, Recent Papuan breeding records: Emu, v. 69, no. 53, p. 235-237.

Beyer, W.N., Connor, E.E., and Gerould, Sarah, 1994, Estimates of soil ingestion by wildlife: Journal of Wildlife Management, v. 58, no. 2, p. 375-382.

Brainard, Rusty, Maragos, Jim, Schroeder, Robert, Kenyon, Jean, Vroom, Peter, Godwin, Scott, Hoeke, Ronald, Aeby, Greta, Moffitt, Russell, Lammers, Marc, Gove, Jamison, Timmers, Molly, Holzwarth, Stephani, and Kolinski, Steve, 2005, The state of coral reef ecosystems of the U.S. Pacific remote island areas, in Waddell, J., ed., The state of coral reef ecosystems of the United States and Pacific Freely Associated States, NOAA Technical Memorandum NOS NCCOS 11. NOAA/NCCOS: Silver Spring, Md., Center for Coastal Monitoring and Assessment's Biogeography Team, p. 338-372.

Buckelew, Stacey, Howald, G.R., Wegmann, Alex, Sheppard, Jacob, Curl, Jennifer, McClelland, Pete, Tershy, Bernie, Swift, Katie, Campbell, Earl, and Flint, Beth, 2005, Progress in Palmyra Atoll restoration - rat eradication trial, 2005: Santa Cruz, Calif., Island Conservation Report to U.S. Fish and Wildlife Service, $50 \mathrm{p}$.

Burger, A.E., 2005, Avian dispersal of Pisonia grandis, an Indo-Pacific tropical tree associated with seabird colonies: Journal of Tropical Ecology, v. 21, p. 263-271.

Carlquist, S., 1974, Island biology: New York, Columbia University Press, 656 p.

Caut, Stephane, Angulo, Elane, and Courchamp, Franck, 2008, Dietary shift of an invasive predatorrats, seabirds and sea turtles: Journal of Applied Ecology, v. 45, no. 7, p. 428-437.

Chambers, S.M., Hitchcock, C.J., and Cairney, J.W.G., 2005, Ectomycorrhizal mycobionts on Pisonia grandis on coral cays in the Capricorn-Bunker group. Great Barrier Reef, Australia: Mycological Research, v. 109, no. 10, p. 1105-1111.

Christensen, N.L., Bartuska, Ann, Brown, J.H., Carpenter, Stephen, D’Antonio, Carla, Francis, Rober, Franklin, J.F., Mac Mahon, J.A., Noss, R.F., Parsons, D.J., Peterson, C.H., Turner, M.G., and Woodmansee, R.G., 1996, The report of the Ecological Society of America Committee on the scientific basis for ecosystem management: Ecological Applications, v. 6, no. 3, p. 665-691.

Christophersen, Erling, 1927, Vegetation of Pacific equatorial islands: Bishop Museum Bulletin, v. 44, no. 2, p. 1-79. 
Citta, John, Reynolds, M.H., and Seavy, N.E., 2006, Seabird monitoring assessment for Hawai $i$ and the Pacific Islands: Prepared for the U.S. Fish and Wildlife Service, 122 p.

Collen, J.D., Garton, D.W., and Gardner J.P.A., 2009, Shoreline changes and sediment redistribution at Palmyra Atoll (Equatorial Pacific Ocean)-1874-Present: Journal of Coastal Research, v. 25, no. 3, p. 711-722.

Dawson, E.Y., 1959, Changes in Palmyra Atoll and its vegetation through the activities of man, 19131958: Pacific Naturalist, v. 1, no. 2, p. 1-51.

Department of the Interior Secretarial Order No. 3224, 18 January 2001, Palmyra Atoll National Wildlife Refuge, accessed September 1, 2009 at

http://elips.doi.gov/app_so/act_getfiles.cfm?order_number $=3224$.

Depkin, C.D., 2002, Trip report to Palmyra Atoll, 06 August 2001-07 October 2002: Honolulu, Hawai i, U.S. Fish and Wildlife Service, 133 p.

Eldredge, L.G., 1996, Birgus latro, in IUCN 2009, IUCN Red List of Threatened Species. Version 2009.1., accessed September 1, 2009 at http://www.iucnredlist.org/apps/redlist/details/2811/0.)

Engilis, Jr., Andrew, and Naughton, Maura 2004, U.S. Pacific Islands regional shorebird conservation plan. U.S. Shorebird Conservation Plan: Portland, Oreg., U.S. Department of the Interior, Fish and Wildlife Service, $67 \mathrm{p}$.

Environmental Chemical Corporation, 1998, Draft closure report remedial action Palmyra Atoll, Palmyra USA. USACE Contract No. DACA83-95-D-0002. Prepared for the Department of the Army, U.S. Army Corps of Engineers Pacific Ocean Division, 406 p.

Falkland, Anthony, 2002, Tropical island hydrology and water resources - current knowledge and future needs, in Hydrology and water resources management in the humid tropics. Proceedings-Second International Colloquium, Panama, Republic of Panama, 22-26 March 1992. UNESCO-IHP-V technical documents in hydrology no. 52: Paris, UNESCO, p. 237-372.

Fefer, S.I., 1987, Trip report to Palmyra Atoll, 16-30 September 1987: Honolulu, Hawai'i, U.S. Fish and Wildlife Service Administrative Report, $31 \mathrm{p}$.

Finkelstein, M.E., Grasman, K.A., Croll, D.A., Tershy, B.R., Keitt, B.S., Jaman, W.M., and Smith, D.R., 2007, Contaminant-associated alteration of immune function in black-footed albatross (Phoebastria nigripes), a North Pacific predator: Environmental Toxicology and Chemistry, v. 26 , no. 9, p. 1896-1903.

Fisher, R.N., and Hathaway, S.A., 2007, Scientific scoping trip to Palmyra September 28-October 12, 2007: Honolulu, Hawai i, U.S. Fish and Wildlife Service Administrative Report, 5 p.

Flint, Elizabeth, 1999, Status of seabird populations and conservation in the tropical island Pacific, in Eldredge, L.G., Maragos, J.E., Holthus, P.F., and Takeuchi, H.F., eds., Marine and coastal biodiversity in the tropical island Pacific region - population, development, and conservation priorities, v. 2: Honolulu, Hawai i, East-West Center, p. 189-210.

Flint, Elizabeth, Herbst, Derral, McDermond, Ken, Woodside, David, and Yuen, Andy, 1992, Survey of the terrestrial biota of Palmyra Atoll 18 February to 9 March 1992: Honolulu, Hawai i, U.S. Fish and Wildlife Service Administrative Report, 19 p.

Fosberg, F.R., 1953, Vegetation of central Pacific atolls: Atoll Research Bulletin, v. 23, p. 1-26.

Fosberg, F.R., 1954, Soils of the northern Marshall Atolls with special reference to the Jemo Series: Soil Science, v. 78, no. 2, p. 99-108.

Fosberg, F.R., 1957, Description and occurrence of atoll phosphate rock: American Journal of Science, V. 255 , no. 8 , p. 584-592.

Fosberg, F.R., 1994, Comments on atoll phosphate rock: Atoll Research Bulletin, v. 396, p. 1-5. 
Freeman, Scott, 2006a, Vascular flora of Palmyra Atoll — an update to 1992: Honolulu, Hawai i, U.S. Fish and Wildlife Service Administrative Report, 28 p.

Freeman, Scott, 2006b, Plants of Palmyra - an unofficial guide to the vascular flora of Palmyra Atoll: Honolulu, Hawai i, U.S. Fish and Wildlife Service Administrative Report, 86 p.

Freeman, Scott, 2006c, The Palmyra Pisonia report—February 2006 (draft): Honolulu, Hawai i, U.S. Fish and Wildlife Service Administrative Report.

Fry, D.M., Fefer, S.I., and Sileo, Louis, 1987, Ingestion of plastic debris by Laysan albatrosses and wedge-tailed shearwaters in the Hawai ian Islands: Marine Pollution Bulletin, v. 18, no. 6 part b, p. 339-343.

Gerhing, Catherine, and Bennett, Alison, 2009, Fungal-plant-insect interactions - the importance of a community approach: Environmental Entomology, v. 38, no. 1, p. 93-102.

Grant-Hoffman, M.N., Mulder, C.P.H., and Bellingham, P.J., 2010, Effects of invasive rats and burrowing seabirds on seeds and seedlings on New Zealand islands: Oecologica, v. 162, no. 4, p. 1005-1016.

Greenslade, Penelope, 2008, Climate variability, biological control and an insect pest outbreak on Australia's Coral Sea islets: lessons for invertebrate conservation: Journal of Insect Conservation, $v$. 12, no. 3-4, p. 333-342.

Gross, W.J., 1964, Water balance in anomuran land crabs on a dry atoll: Biological Bulletin, v. 126, no. 1, p. 54-68.

Handler, A.T., Gruner, D.S., Haines, W.P., Lange, M.W., and Kaneshiro, K.Y., 2007, Arthropod surveys on Palmyra Atoll, Line Islands, and insights into the decline of the native tree Pisonia grandis (Nyctaginaceae): Pacific Science, v. 61, no. 4, p. 485-502.

Handler, A.T., and James, S.A., 2006, Anguilla marmorata (giant mottled eel) discovered in a new location-natural range expansion or recent human introduction?: Pacific Science, v. 60, no. 1 p. 109 115.

Hathaway, S.A., and Fisher, R.N., 2010, Biosecurity plan for Palmyra Atoll: U.S. Geological Survey Open-File Report 2010-1097, 80 p.

Hatheway, W.H., 1955, The natural vegetation of Canton Island, an equatorial Pacific atoll: Atoll Research Bulletin, v. 43, p. 1-10.

Henderson, J.R., 2001, A pre- and post-MARPOL Annex V summary of Hawai ian monk seal entanglements and marine debris accumulation in the northwestern Hawai ian Islands, 1982-1998: Marine Pollution Bulletin, v. 42, no. 7, p. 584-589.

Herbst, Derral, 1988, Flora and vegetation of Palmyra Atoll: Honolulu, Hawai i, U.S. Fish and Wildlife Service Administrative Report, 37 p.

Herbst, Derral, 1992, Flora and vegetation of Palmyra Atoll: Honolulu, Hawai i, U.S. Fish and Wildlife Service Administrative Report, $31 \mathrm{p}$.

Hoffman, B.D., and Kay, Alice, 2009, Pisonia grandis monocultures limit the spread of an invasive ant - a case of carbohydrate quality?: Biological Invasions, v. 11, no. 6, p. 1403-1410.

Howald, Gregg, Samaniego, Araceli, Buckelew, Stacey, McClelland, Pete, Keitt, Bradford, Wegmann, Alex, Pitt, W.C., Vice, D.S., Campbell, Earl, Swift, Katie, and Barclay, Steve, 2004, Palmyra Atoll rat eradication assessment_-Trip report, August 2004: Santa Cruz, Calif., Island Conservation, Report to U.S. Fish and Wildlife Service, $61 \mathrm{p}$.

Hui, C.A., and Beyer, W.N., 1998, Sediment ingestion of two sympatric shorebird species: Science of the Total Environment, v. 224, no. 1-3, p. 227-233. 
Intergovernmental Panel on Climate Change, 2007, Climate change 2007-the physical science basis. Contribution of Working Group I to the Fourth Assessment Report of the Intergovernmental Panel on Climate Change: Solomon, Susan, Qin, Dahe, Manning, Martin, Chen, Zhenlin, Marquis, Melinda, Averyt, K.B., Tignor, M.M.B., and Miller, H.L., eds., Cambridge, United Kingdom and New York, Cambridge University Press, 996 p.

Jones, H.P., Tershy, B.R., Zaveleta, E.S., Croll, D.A., Keitt, B.S., Finkelstein, M.E., and Howald, G.R., 2008, Severity of the effects of invasive rats on seabirds - a global review: Conservation Biology, v. 22 , no. 1, p. 16-26.

Keating, B.H., 1992, Insular geology of the Line Islands, in Keating, B.H., and Bolton, B.R., eds., Geology and offshore mineral resources of the Central Pacific Basin. Circum-Pacific Council for Energy and Mineral Resources: Earth Sciences Series, p. 77-99.

Kepler, A.K., and Kepler, C.B., 1994, Part I. History, physiography, botany, and isle description: Atoll Research Bulletin, v. 397, p. 1-225.

Kuris, A.M., 2003, Did biological control cause extinction of the coconut moth, Levuana iridescens, in Fiji?: Biological Invasions, v. 5, no. 1-2, p. 133-141.

Kushlan, J.A., Steinkamp, M.J., Parsons, K.C., Capp, Jack, Acosta Cruz, Martin, Coulter, Malcolm, Davidson, Ian, Dickson, Loney, Edelson, Naomi, Elliot, Richard, Erwin, R.M., Hatch, Scott, Kress, Stephen, Milko, Robert, Miller, Steve, Mills, Kyra, Paul, Richard, Phillips, Roberto, Saliva, J.E., Sydeman, Bill, Trapp, John, Wheeler, Jennifer and Wohl, Kent, 2002, Waterbird conservation for the Americas - the North American Waterbird Conservation Plan, version 1: Washington, D.C., Waterbird Conservation for the Americas, $78 \mathrm{p}$.

Kyle, J.L., and Harris, Eva, 2008, Global spread and persistence of dengue: Annual Review of Microbiology, v. 62, p. 71-92.

Ladeau, S.L., Marra, P.P., Kilpatrick, A.M., and Calder, C.A., 2008, West Nile Virus revisitedconsequences for North American ecology: BioScience, v. 58, no. 10, p. 937-946.

Lafferty, K.D., Hathaway, S.A., Wegmann, A.S., Shipley, F.S., Backlin, A.R., Helm, Joel, and Fisher, R.N., 2010, Stomach nematodes (Mastophorus muris) in rats (Rattus rattus) are associated with coconut (Cocos nucifera) habitat at Palmyra Atoll: Journal of Parasitology, v. 96, no. 1, p. 16-20.

Lafferty, K.D., and Kushner, David, 2008, Draft initial monitoring plan for Palmyra Atoll: Sacramento, Calif., U.S. Geological Survey, Western Ecological Research Center, 74 p.

Lavery, S., Moritz, Craig, and Fielder, D.R., 1996, Indo-Pacific population structure and evolutionary history of the coconut crab Birgus latro: Molecular Ecology, v. 5, no. 4, p. 557-570.

Lee, M.A.B., 1984, Biogeography and ecology of atoll plants: Progress in Physical Geography, v. 8, no. 4, p. 509-522.

Maragos, J.E., 1993, Impact of coastal construction on coral-reefs in the United-States-affiliated Pacific islands, v. 21, no. 4, p. 235-269.

McEachern, Kathryn, and Hathaway, S.A., 2008, Trip report, Palmyra Atoll, May 21-28, 2008 terrestrial ecology: Honolulu, Hawai i, U.S. Fish and Wildlife Service Administrative Report, 5 p.

Mueller-Dombois, Dieter, and Fosberg. F.R., 1998, Vegetation of the tropical Pacific islands: New York, Springer-Verlag, 773 p.

National Invasive Species Council, 2008, 2008-2012 National Invasive Species Management Plan, 35 p.

National Wildlife Refuge System Improvement Act of 1997, 1997, Public Law 105-57, accessed September 1, 2009 at http://www.fws.gov/refuges/policiesandbudget/HR1420_index.html

Niering, W.A., 1963, Terrestrial ecology of Kapingamarangi, Caroline Islands: Ecological Monographs, v. 33, no. 2, p. 131-160. 
Nonner, Edith, 2005, FY05 forest health protection accomplishment report for Palmyra Atoll National Wildlife Refuge: Honolulu, Hawai i, U.S. Fish and Wildlife Service Administrative Report.

Nonner, Edith., 2008, Scale population dynamics and control measures and the status of Pisonia grandis at Palmyra Atoll NWR in 2007-presentation at the $89^{\text {th }}$ annual meeting of the American Association for the Advancement of Science Pacific Division.

Nonner, Edith, and Woodward, Lee Ann, 2006, Draft. The decline of Pisonia grandis at Palmyra Atoll NWR - factors and solutions: Honolulu, Hawai i, U.S. Fish and Wildlife Service Administrative Report, $28 \mathrm{p}$.

O'Grady, A.P., Eamus, Derek, Cook, P.O., and Lamontagne, Sebastien, 2006, Groundwater use by riparian vegetation in the wet-dry tropics of northern Australia: Australian Journal of Botany, v. 54, no. 2, p. 145-154.

Pacific Invasive Ant Group, 2004, Pacific ant prevention plan-a proposal prepared for the Pacific Plant Protection Organization and Regional Technical Meeting for Plant Protection, March 2004, 29 p.

Polis, G.A., and Hurd, S.D., 1996, Linking marine and terrestrial food webs — allochthonous input from the ocean supports high secondary productivity on small islands and coastal land communities: The American Naturalist, v. 147, no. 3, p. 396-423.

Reyne, A., 1939, On the food habits of the coconut crab (Birgus latro L.) with notes on its distribution: Archives Néerlandaises de Zoologie, v. 3, p. 282-320.

Rivière F., Klein, J.M., Thirel, R., and Chebret, M., 1998, Ecologie d'Aedes polynesiensis Marks, 1951 (Diptera : Culicidae) vecteur de la filariose de Bancroft. I. - Les noix de coco rongées par les rats comme gîtes larvaires: Annales de la Société Entomologique de France, v. 34, no. 22, p. 195-207.

R.M. Towill Corporation, 1993, Palmyra Atoll remediation plan Palmyra Atoll, Line Islands $160^{\circ}, 06^{\prime}$ west longitude, $5^{\circ}, 52^{\prime}$ north latitude: Prepared for Department of the Army, United States Army Corps of Engineers Pacific Ocean Division, Fort Shafter, Oahu, Hawai i, 558 p.

Rock, J.F., 1929, The voyage of the Luka to Palmyra Island: Atlantic Monthly, v. 144, no. 9, p. 560566.

Ryan, P.G., Connell, A.D., and Gardner, B.D., 1988, Plastic ingestion and PCBs in seabirds-is there a relationship?: Marine Pollution Bulletin, v. 18, no. 5, p. 217-219.

Sadler, J.C., 1959, A study of some recent climatological data of the Line Islands: Proceedings of the Ninth Pacific Science Congress of the Pacific Science Association, Department of Science, Bangkok, Thailand, p. 12-16.

Schmidt, Susanne, Dennison, W.C., Moss, G.J., and Stewart G.R., 2004, Nitrogen ecophysiology of Heron Island, a subtropical coral cay of the Great Barrier Reef, Australia: Functional Plant Biology, v. 31 , no. 5, p. 519-528.

Shea, E.L., Dolcemascolo, Glenn, Anderson, C.L., Barnston, Anthony, Guard, C.P., Hamnett, M.P., Kubota, S.T., Lewis, Nancy, Loschnigg, Johannes, and Meehl, Gerald, 2001, Preparing for a changing climate - the potential consequences of climate variability and change: Honolulu, Hawai i, East-West Center, $100 \mathrm{p}$.

Society for Ecological Restoration International Science and Policy Working Group, 2004, The SER international primer on ecological restoration, Tucson: Society for Ecological Restoration International, accessed September1, 2009, http://www.ser.org/content/ecological_restoration_primer.asp.

Spear, L.B., Ainley, D.G., and Ribic, C.A.A., 1995, Incidence of plastic in seabirds from the tropical Pacific, 1984-91 - relation with distribution of species, sex, age, season, year and body-weight: Marine Environmental Research, v. 40, no. 2, p. 123-146. 
Spicer, R.A., and Newberry, D.M., 1979, The terrestrial vegetation of an Indian Ocean coral islandWilingili, Addu Atoll, Maldive Islands: Atoll Research Bulletin, v. 231, p. 1-14.

Streets, T.H., 1877, Some account of the natural history of the Fanning group of islands: American Naturalist, v. 11, no. 2, p. 65-72.

Suchanek, Tom, Hart, Kristen, Kulongoski, Justin, Lafferty, Kevin, and Sandoval, Cristina, 2007, Palmyra Atoll, mid Pacific 28 October-6 November 2007: Honolulu, Hawai i, U.S. Fish and Wildlife Service Administrative Report, 10 p.

Towns, D.R., Atkinson, I.A.E., and Daugherty, C.H., 2006, Have the harmful effects of introduced rats on islands been exaggerated?: Biological Invasions, v. 8, p. 863-891.

Towns, D.R., Wardle, D.A., Mulder, C.P.H., Yeates, G.W., Fitzgerald, B.M., Parish, G.R., Bellingham, P.J., and Bonner, K.I., 2009, Predation of seabirds by invasive rats - multiple indirect consequences for invertebrate communities: Oikos, v. 118, no. 3, p. 420-430.

Tribble, Gordon, 2008, Ground water on tropical Pacific Islands-understanding a vital resource: U.S. Geological Survey Circular 1312, 35 p.

Underwood, M.R., Peterson, F.L., and Voss, C.I., 1992, Groundwater lens dynamics for atoll islands: Water Resources Research, v. 28, no. 11, p. 2889-2902.

U.S. Fish and Wildlife Service, 2001, Biological integrity, diversity, and environmental health: Policy 601 FW 3, accessed September1, 2009, http://www.fws.gov/policy/601fw3.html.

U.S. Fish and Wildlife Service, 2002, Birds of conservation concern 2002: Arlington, Va., Division of Migratory Bird Management, 99 p., accessed September1, 2009, http://www.fws.gov/pacific/migratorybirds/BCC2002.pdf.

U.S. Fish and Wildlife Service, 2004, Palmyra ant control preliminary experiments: Honolulu, Hawai i, U.S. Fish and Wildlife Service Administrative Report.

U.S. Fish and Wildlife Service, 2005, Regional seabird conservation plan, Pacific region: Portland, Oreg., U.S. Fish and Wildlife Service, Migratory Birds and Habitat Programs, Pacific Region, 262 p.

U.S. Fish and Wildlife Service, 2006, National wildlife refuge system mission and goals and refuge purposes $601 \mathrm{FW} \mathrm{1,} \mathrm{accessed} \mathrm{September1,} \mathrm{2009,} \mathrm{http://www.fws.gov/policy/601fwl.html.}$

U.S. Fish and Wildlife Service, 2007, Palmyra Atoll National Wildlife Refuge and Kingman Reef National Wildlife Refuge: Federal Register, v. 72, no. 87, p. 25771-25773.

Usinger, R.L., and La Rivers, Ira, 1953, The insect life of Arno: Atoll Research Bulletin, v. 15, p. 1-28. van Riper III, Charles, van Riper, S.G., and Hansen, W.R., 2002, Epizootiology and effect of avian pox on Hawai ian forest birds: The Auk, v. 119, no. 4, p. 929-942.

Veitch, C.R., and Clout, M.N., 2002, Turning the tide - the eradication of invasive speciesProceedings of the International Conference on the Eradication of Island Invasives: Gland, Switzerland, and Cambridge, U.K., IUCN SSC Invasive Species Specialist Group, 414 p.

Vitousek, P.M., 1990, Biological invasions and ecosystem processes-towards an integration of population biology and ecosystem studies: Oikos, v. 57, no. 1, p. 7-13.

Vranjic J.A., 1997, Effects on host plant, in Ben-Dov, Yair, and Hodgson, C.J., eds., Soft scale insects - their biology, natural enemies and control, world crop pests, v. 7B: Amsterdam, Elsevier Science B.V., 422 p.

Walker, T.A., 1991, Pisonia Islands of the Great Barrier Reef, part 1-the distribution, abundance, and dispersal by sea birds of Pisonia grandis: Atoll Research Bulletin, v. 350, part 1, p. 1-23.

Ward, S.H., ed., 1990, Geotechnical and environmental geophysics, v. 2-3: Tulsa, Oklahoma, Society of Exploration Geophysics.

Way, M.J., 1963, Mutualism between ants and honeydew-producing Homoptera: Annual Review of Entomology, v. 8, p. 307-344. 
Wegmann, Alex, 2005, Palmyra Atoll National Wildlife Refuge forest type map: Honolulu, Hawai i, U.S. Fish and Wildlife Service.

Wells, S.M., Pyle, R.M., and Collins, N.M., 1983, IUCN invertebrate red data book-a contribution to the Global Environment Monitoring System: Gland, Switzerland accessed September 1, 2009 at http://www.iucnredlist.org/apps/redlist/details/2811/0.

Wetterer, J.K., 2007, Biology and impacts of Pacific island invasive species. 3. The African big-headed ant, Pheidole megacephala (Hymenoptera: Formicidae): Pacific Science, v. 61, no. 4, p. 437-456.

White, Ian, Falkland, Tony, Perez, Pascal, Dray, Anne, Metutera, Taboia, Metai, Eita, and Overmars, Marc, 2007, Challenges in freshwater management in low coral atolls: Journal of Cleaner Production, v. 15 , p. $1522-1528$.

Wiens, H.J., 1962, Atoll environment and ecology: New Haven-London, Yale University Press, 532 p.

Wil Chee Planning Inc. and SCS Engineers, 1998, Soil boring/monitoring well logs from hospital dump site, Palmyra Atoll, Palmyra, U.S.A.: Honolulu, Hawai i, prepared for Wil Chee - Planning by SCS Engineers, $60 \mathrm{p}$.

Wood, C.M., and Boutilier, R.G., 1985, Osmoregulation, ionic exchange, blood chemistry, and nitrogenous waste excretion in the land crab Cardisoma carnifex - a field and laboratory study: Biological Bulletin, v. 169, no. 1, p. 267-290.

Woodward, L.A., 2000, U.S. Fish and Wildlife Service Pacific Islands Ecoregion Level I PreAcquisition Contaminant Survey for the proposed Palmyra Atoll National Wildlife Refuge: Honolulu, Hawai i, U.S. Fish and Wildlife Service Administrative Report, 28 p.

Woodward, Lee Ann, 2001, U.S. Fish and Wildlife Service Pacific Islands Ecoregion Environmental Site Assessment Level III Survey: Honolulu, Hawai i, U.S. Fish and Wildlife Service Administrative Report, $36 \mathrm{p}$.

Young, H.S., McCauley, D.J., Dunbar, R.B., and Dirzo, Rodolfo, 2010a, Plants cause ecosystem nutrient depletion via the interruption of bird-derived spatial subsidies: Proceedings of the National Academy of Sciences, v. 107, no. 5, p. 2072-2077.

Young, H.S., Raab, T.K., McCauley, D.J., Briggs, A.A., and Dirzo, Rodolfo, 2010a, The coconut palm, Cocos nucifera, impacts forest composition and soil characteristics at Palmyra Atoll, Central Pacific: Journal of Vegetation Science, v. 21, no. 6, p. 1058-1068.

Young, H.S., Shaffer, S.A., McCauley, D.J., Foley, D.G., Dirzo, Rodolfo, and Block, B.A., 2010c, Resource partitioning by species but not sex in sympatric boobies in the Central Pacific Ocean: Marine Ecology Progress Series, v. 403, p. 291-301. 
Table 1. Terrestrial plant species that have been identified at Palmyra Atoll.

[Status listed according to Freeman (2006a) with native species shown in bold, species reported as no longer occurring grayed out, and contradictory assignments for distribution (D) and abundance (A) shown in boxes (modified from Herbst, 1992, and Freeman, 2006a, b). $\mathrm{D}=$ Distribution across the whole of Palmyra Atoll: $\mathrm{W}=$ Widespread $(>12$ islets), $\mathrm{S}=$ Scattered (6-12 islets), $\mathrm{L}=$ Limited (1-5 islets), $\mathrm{X}=$ Extinct on Palmyra Atoll (0 islets). A = Abundance across whole of Palmyra Atoll: $\mathrm{A}=$ Abundant, $\mathrm{C}=$ Common, $\mathrm{U}=$ Uncommon, $\mathrm{R}=$ Rare, $\mathrm{P}=$ Present (for cultivated species), and $\mathrm{X}=$ Extinct on Palmyra Atoll]

\begin{tabular}{|c|c|c|c|}
\hline Species & Status & $\mathbf{D}$ & A \\
\hline Abelmoschus sp. & nonnative & $\mathrm{L}$ & $\mathrm{P}$ \\
\hline $\begin{array}{l}\text { Acalypha wilkesiana } \\
\text { Allium cepa }\end{array}$ & $\begin{array}{l}\text { cultivated ornamental plant no longer occurring } \\
\text { cultivated food plants no longer occurring }\end{array}$ & $\begin{array}{l}X \\
X\end{array}$ & $\begin{array}{l}\mathrm{X} \\
\mathrm{X}\end{array}$ \\
\hline Aloe vera & nonnative & $\mathrm{L}$ & $\mathrm{P}$ \\
\hline $\begin{array}{l}\text { Anacardium occidentale } \\
\text { Ananas comosus } \\
\text { Annona sp. }\end{array}$ & $\begin{array}{l}\text { cultivated food plants no longer occurring } \\
\text { cultivated food plants no longer occurring } \\
\text { cultivated food plants no longer occurring }\end{array}$ & $\begin{array}{l}X \\
X \\
X\end{array}$ & $\begin{array}{l}X \\
X \\
X\end{array}$ \\
\hline $\begin{array}{l}\text { Araucaria sp. } \\
\text { Artocarpus altilis }\end{array}$ & $\begin{array}{l}\text { nonnative } \\
\text { nonnative }\end{array}$ & $\begin{array}{l}\mathrm{L} \\
\mathrm{L}\end{array}$ & $\begin{array}{l}\mathrm{P} \\
\mathrm{P}\end{array}$ \\
\hline Asparagus sp. & cultivated food plants no longer occurring & $X$ & $\mathrm{X}$ \\
\hline Asplenium nidus & native & $\mathbf{W}$ & $\mathbf{U}$ \\
\hline Barringtonia asiatica & native & $\mathbf{L}$ & $\mathbf{R}$ \\
\hline Bidens alba & nonnative & $\mathrm{L}$ & $\mathrm{R}$ \\
\hline Boerhavia tetranda & native & $\mathbf{S}$ & $\mathbf{U}$ \\
\hline Bolboshoenus sp. & native & $\mathbf{L}$ & $\mathbf{U}$ \\
\hline Caesalpinia major & native & $\mathbf{X}$ & $\mathbf{X}$ \\
\hline Calophyllum inophyllum & nonnative & $X^{1}$ & $\mathrm{U}$ \\
\hline Cannabis indica & cultivated ornamental plant no longer occurring & $\mathrm{X}$ & $\mathrm{X}$ \\
\hline Carica papaya & nonnative & $\mathrm{L}$ & $\mathrm{P}$ \\
\hline Casuarina equisetifolia & nonnative & $\mathrm{L}$ & $\mathrm{R}$ \\
\hline Cenchrus echinatus & accidental no longer occurring & $\mathrm{X}$ & $\mathrm{X}$ \\
\hline Chamaesyce hirta & nonnative & $\mathrm{L}$ & $\mathrm{C}$ \\
\hline Chamaesyce hypericifolia & nonnative & $\mathrm{L}$ & $\mathrm{C}$ \\
\hline Chamaesyce hyssopifolia & nonnative & 2 & \\
\hline Chloris inflata & nonnative & $\mathrm{L}$ & $\mathrm{U}$ \\
\hline \multirow{2}{*}{$\begin{array}{l}\text { Citrullus lanatus } \\
\text { Citrus aurantium }\end{array}$} & \multirow{2}{*}{$\begin{array}{l}\text { cultivated ornamental plant no longer occurring } \\
\text { cultivated food plants no longer occurring }\end{array}$} & $\mathrm{X}$ & $\mathrm{X}$ \\
\hline & & $\mathrm{L}$ & $\mathrm{X}$ \\
\hline \multirow{3}{*}{$\begin{array}{l}\text { Citrus sp. } \\
\text { Coccoloba uvifera } \\
\text { Cocos nucifera }\end{array}$} & \multirow{3}{*}{$\begin{array}{l}\text { nonnative } \\
\text { nonnative } \\
\text { possibly nonnative }\end{array}$} & $\mathrm{L}$ & $\mathrm{P}$ \\
\hline & & $\mathrm{X}^{1}$ & $\mathrm{U}$ \\
\hline & & $\mathrm{W}$ & A \\
\hline Codiaeum variegatum var. pictum & cultivated ornamental plant no longer occurring & $\mathrm{X}$ & $\mathrm{X}$ \\
\hline Conyza bonariensis & nonnative & $\mathrm{X}$ & $\mathrm{C}$ \\
\hline
\end{tabular}


Table 1. Terrestrial plant species that have been identified at Palmyra Atoll._Continued

\begin{tabular}{|c|c|c|c|}
\hline Species & Status & D & A \\
\hline Cordia subcordata & native & $\mathbf{L}$ & $\mathbf{R}$ \\
\hline Cordyline fruticosa & cultivated ornamental plant no longer occurring & $\mathrm{X}$ & $\mathrm{X}$ \\
\hline Crocus & nonnative & $\mathrm{L}$ & $\mathrm{P}$ \\
\hline Crotalaria incana & nonnative & $\mathrm{L}$ & $\mathrm{U}$ \\
\hline Cucumus sativus & cultivated food plants no longer occurring & $\mathrm{X}$ & $\mathrm{X}$ \\
\hline Cyperrus rotundus & nonnative & 2 & \\
\hline \multirow{2}{*}{$\begin{array}{l}\text { Cyperus alternifolius } \\
\text { Cyrtosperma chamissonis }\end{array}$} & \multirow{2}{*}{$\begin{array}{l}\text { accidental no longer occurring } \\
\text { cultivated ornamental plant no longer occurring }\end{array}$} & $\mathrm{X}$ & $\mathrm{X}$ \\
\hline & & $\mathrm{L}$ & $\mathrm{X}$ \\
\hline Digitaria pacifica & nonnative & $\mathrm{L}$ & $\mathrm{U}$ \\
\hline Digitaria setigera & nonnative & $\mathrm{L}$ & $\mathrm{U}$ \\
\hline \multirow{3}{*}{$\begin{array}{l}\text { Eleusine indica } \\
\text { Emilia sonchifolia } \\
\text { Entada phaseoloides }\end{array}$} & \multirow{3}{*}{$\begin{array}{l}\text { nonnative } \\
\text { accidental no longer occurring } \\
\text { native }\end{array}$} & $\mathrm{X}$ & $\mathrm{X}$ \\
\hline & & $\mathrm{L}$ & $\mathrm{X}$ \\
\hline & & $\mathbf{X}$ & $\mathbf{X}$ \\
\hline \multirow{3}{*}{$\begin{array}{l}\text { Epipremnum pinnatum } \\
\text { Eragrostis scabriflora } \\
\text { Eragrostis tenella }\end{array}$} & \multirow{3}{*}{$\begin{array}{l}\text { nonnative } \\
\text { nonnative } \\
\text { nonnative }\end{array}$} & $\mathrm{X}^{1}$ & $\mathrm{C}$ \\
\hline & & $\mathrm{L}$ & $\mathrm{R}$ \\
\hline & & $\mathrm{L}$ & $\mathrm{U}$ \\
\hline Erectites hieracifolia & accidental no longer occurring & $\mathrm{X}$ & $\mathrm{X}$ \\
\hline Erythrina variegate var. orientalis & nonnative & $\mathrm{L}$ & $\mathrm{X}$ \\
\hline Euphorbia cyanthophora & cultivated ornamental plant no longer occurring & $\mathrm{X}$ & $\mathrm{X}$ \\
\hline Euphorbia pulcherrima & cultivated ornamental plant no longer occurring & $\mathrm{X}$ & $\mathrm{X}$ \\
\hline Fimbristylis cymosa & native & $\mathbf{L}$ & $\mathbf{U}$ \\
\hline Graptophyllum pictum & cultivated ornamental plant no longer occurring & $\mathrm{X}$ & $\mathrm{X}$ \\
\hline Guettarda speciosa & native & $\mathbf{L}$ & $\mathbf{R}$ \\
\hline Hemigraphis reptans & accidental no longer occurring & $\mathrm{L}$ & $\mathrm{U}$ \\
\hline \multirow{3}{*}{$\begin{array}{l}\text { Hernandia sonora } \\
\text { Hibiscus rosa-sinensis } \\
\text { Hibiscus tiliaceus }\end{array}$} & \multirow{3}{*}{$\begin{array}{l}\text { native } \\
\text { nonnative } \\
\text { possibly nonnative }\end{array}$} & $\mathbf{S}$ & $\mathbf{R}$ \\
\hline & & $\mathrm{X}^{1}$ & $\mathrm{P}$ \\
\hline & & $\mathrm{S}$ & $\mathrm{C}$ \\
\hline Ipomoea batatas & nonnative & $\mathrm{X}$ & $\mathrm{X}$ \\
\hline Ipomoea pes-caprae ssp. brasiliensis & nonnative & $\mathrm{L}$ & $\mathrm{C}$ \\
\hline Ipomoea violacea & native & $\mathbf{S}$ & $\mathbf{C}$ \\
\hline Kyllinga brevifolia & nonnative & $\mathrm{L}$ & $\mathrm{C}$ \\
\hline Laportea ruderalis & native & $\mathbf{W}$ & $\mathbf{C}$ \\
\hline Lepidium bidentatum & native & $\mathbf{L}$ & $\mathbf{X}^{3}$ \\
\hline Lepturus repens var. palmyrensis & native & $\mathbf{W}$ & $\mathbf{A}$ \\
\hline Leucaena leucocephala & nonnative & $\mathrm{L}$ & $\mathrm{R}$ \\
\hline Ludwigia octovalvis & nonnative & $\mathrm{L}$ & $\mathrm{C}$ \\
\hline Lycopersicon esculentum & nonnative & $\mathrm{L}$ & $\mathrm{P}$ \\
\hline Mangifera indica & nonnative & $\mathrm{L}$ & $\mathrm{P}$ \\
\hline
\end{tabular}


Table 1. Terrestrial plant species that have been identified at Palmyra Atoll._Continued

\begin{tabular}{|c|c|c|c|}
\hline Species & Status & D & A \\
\hline Mariscus javanicus & native & $\mathbf{L}$ & $\mathbf{U}$ \\
\hline Mentha sp. & nonnative & $\mathrm{L}$ & $\mathrm{P}$ \\
\hline Morus sp. & cultivated food plants no longer occurring & $\mathrm{L}$ & $\mathrm{X}$ \\
\hline Musa xparadisiaca & nonnative & $\mathrm{L}$ & $\mathrm{P}$ \\
\hline Neisosperma oppositifolia & native & $\mathbf{X}^{1}$ & $\mathbf{R}$ \\
\hline Nephrolepis hirsutula & nonnative & $\mathrm{L}$ & $\mathrm{U}$ \\
\hline Nothopanax scutellarum & cultivated ornamental plant no longer occurring & $\mathrm{X}$ & $\mathrm{X}$ \\
\hline Ocimum basilicum & nonnative & $\mathrm{L}$ & $\mathrm{P}$ \\
\hline Ophioglossum petiolata & accidental no longer occurring & $\mathrm{X}$ & $\mathrm{X}$ \\
\hline Orchid & nonnative & $\mathrm{L}$ & $\mathrm{P}$ \\
\hline Ornamental Ginger & nonnative & $\mathrm{L}$ & $\mathrm{P}$ \\
\hline Oxalis corniculata & accidental no longer occurring & $\mathrm{X}$ & $\mathrm{X}$ \\
\hline Pandanus fischerianus & native & $\mathbf{W}$ & $\mathbf{C}$ \\
\hline Paspalum fimbriatum & accidental no longer occurring & $\mathrm{X}$ & $\mathrm{X}$ \\
\hline Paspalum orbiculare & nonnative & $\mathrm{L}$ & $\mathrm{C}$ \\
\hline Passiflora edulis & cultivated food plants no longer occurring & $\mathrm{L}$ & $\mathrm{X}$ \\
\hline Persea americana & cultivated food plants no longer occurring & $\mathrm{X}$ & $\mathrm{X}$ \\
\hline Phaseolus sp. & cultivated food plants no longer occurring & $\mathrm{X}$ & $\mathrm{X}$ \\
\hline Phoenix sp. & cultivated food plants no longer occurring & $\mathrm{X}$ & $\mathrm{X}$ \\
\hline Phyllanthus amarus & nonnative & $\mathrm{L}$ & $\mathrm{C}$ \\
\hline Phymatosorus scolopendria & native & $\mathbf{W}$ & $\mathbf{A}$ \\
\hline Pilea microphylla & nonnative & $\mathrm{L}$ & $\mathrm{C}$ \\
\hline Pisonia grandis & native & $\mathbf{W}$ & $\mathbf{A}$ \\
\hline Pluchea carolinensis & nonnative & $\mathrm{L}$ & A \\
\hline Pluchea indica & nonnative & $\mathrm{L}$ & $\mathrm{C}$ \\
\hline Pluchea $x$ fosbergii & nonnative & & A \\
\hline Plumeria sp. & cultivated ornamental plant no longer occurring & $\mathrm{X}$ & $\mathrm{X}$ \\
\hline Polyscias balfouriana & cultivated ornamental plant no longer occurring & $\mathrm{X}$ & $\mathrm{X}$ \\
\hline Portulaca oleracea & nonnative & $\mathrm{S}$ & $\mathrm{C}$ \\
\hline Premna serratifolia & native & $\mathbf{L}$ & $\mathbf{R}$ \\
\hline Pseuderanthemum carruthersii & cultivated ornamental plant no longer occurring & $\mathrm{X}$ & $\mathrm{X}$ \\
\hline Psilotum nudum & native & $\mathbf{S}$ & $\mathbf{R}$ \\
\hline Pteris ensiformis & nonnative & $\mathrm{L}$ & $\mathrm{U}$ \\
\hline Pycreus polystachyos & nonnative & $\mathrm{L}$ & $\mathrm{C}$ \\
\hline Raphanus sativus & cultivated food plants no longer occurring & $\mathrm{X}$ & $\mathrm{X}$ \\
\hline Rosa sp. & cultivated ornamental plant no longer occurring & $\mathrm{X}$ & $\mathrm{X}$ \\
\hline Sansevieria trifasciata & cultivated ornamental plant no longer occurring & $\mathrm{X}$ & $\mathrm{X}$ \\
\hline Scaevola sericea & native & W & $\mathbf{A}$ \\
\hline
\end{tabular}


Table 1. Terrestrial plant species that have been identified at Palmyra Atoll._Continued

\begin{tabular}{|l|l|c|c|}
\hline \multicolumn{1}{|c|}{ Species } & \multicolumn{1}{|c|}{ Status } & D & A \\
\hline \multirow{2}{*}{ Shefflera actinophylla } & nonnative & & \\
Sida rhombifolia & accidental no longer occurring & $\mathrm{L}$ & $\mathrm{R}$ \\
Spathoglottis plicata & nonnative & $\mathrm{X}$ & $\mathrm{X}$ \\
Spermacoce assurgens & nonnative & $\mathrm{L}$ & $\mathrm{X}$ \\
Sporobolus indicus & nonnative & $\mathrm{S}$ & $\mathrm{C}$ \\
Stachytarpheta jamaicensis & nonnative & $\mathrm{L}$ & $\mathrm{U}$ \\
Stachytarpheta urticifolia & nonnative & $\mathrm{C}$ \\
Suriana maritima & native & $\mathrm{L}$ & $\mathrm{C}$ \\
Synedrella nodiflora & nonnative & $\mathrm{L}$ & $\mathrm{X}^{4}$ \\
\hline Syzygium malaccense & cultivated ornamental plant no longer occurring & $\mathrm{L}$ & $\mathrm{U}$ \\
\hline Temptations & nonnative & $\mathrm{X}$ \\
Terminalia catappa & possibly nonnative & $\mathrm{L}$ & $\mathrm{P}$ \\
Thespesia populnea & cultivated ornamental plant no longer occurring & $\mathrm{S}$ & $\mathrm{A}$ \\
\hline Tournefortia argentea & native & $\mathrm{L}$ & $\mathrm{X}$ \\
\hline Tridax procumbens & nonnative & W & A \\
Triumfetta procumbens & native & $\mathrm{L}$ & $\mathrm{R}$ \\
Vernonia cinerea var. parviflora & nonnative & L & A \\
Viola sp. & cultivated ornamental plant no longer occurring & $\mathrm{L}$ & $\mathrm{X}$ \\
\hline Vitex trifolia & nonnative & $\mathrm{X}$ \\
Zea mays & cultivated food plants no longer occurring & $\mathrm{R}$ \\
\hline Record & $\mathrm{X}$ & $\mathrm{X}$ \\
\hline
\end{tabular}

${ }^{1}$ Recorded as "extinct" at Palmyra Atoll, but seen at Palmyra Atoll subsequent to these data.

${ }^{2}$ New species record collected by Depkin identification from Herbst (2002); no distribution or abundance data available.

${ }^{3}$ Recorded in Freeman (2006b) as last seen in 1938.

${ }^{4}$ Recorded in Freeman (2006b) as "may be extinct". 
Table 2. Native terrestrial vascular plant species that have been identified at Palmyra Atoll with qualitative descriptions of their distribution and abundance.

[Modified from Herbst (1992) and Freeman (2006a, 2006b). Species reported as no longer occurring grayed out and contradictory assignments for distribution and abundance shown in boxes.

Distribution across the whole of Palmyra Atoll: Widespread ( $>12$ islets), Scattered (6-12 islets),

Limited (1-5 islets), Extinct on Palmyra Atoll (0 islets)]

\begin{tabular}{|c|c|c|}
\hline Species & Distributio & Abundance \\
\hline Asplenium nidus & Widespread & Uncommon \\
\hline Barringtonia asiatica & Limited & Rare \\
\hline Boerhavia tetranda & Scattered & Uncommon \\
\hline Bolboshoenus sp. & Limited & Uncommon \\
\hline Caesalpinia major & Locally extinct & Locally extinct \\
\hline Cordia subcordata & Limited & Rare \\
\hline Entada phaseoloides & Locally extinct & Locally extinct \\
\hline Fimbristylis cymosa & Limited & Uncommon \\
\hline Guettarda speciosa & Limited & Rare \\
\hline Hernandia sonora & Scattered & Rare \\
\hline Ipomoea violacea & Scattered & Common \\
\hline Laportea ruderalis & Widespread & Common \\
\hline Lepidium bidentatum & Limited & Locally extinct $^{1}$ \\
\hline Lepturus repens var. palmyrensis & Widespread & Abundant \\
\hline Mariscus javanicus & Limited & Uncommon \\
\hline Neisosperma oppositifolia & Locally extinct $^{2}$ & Rare \\
\hline Pandanus fischerianus & Widespread & Common \\
\hline Phymatosorus scolopendria & Widespread & Abundant \\
\hline Pisonia grandis & Widespread & Abundant \\
\hline Premna serratifolia & Limited & Rare \\
\hline Psilotum nudum & Scattered & Rare \\
\hline Scaevola sericea & Widespread & Abundant \\
\hline Suriana maritima & Limited & Locally extinct $^{3}$ \\
\hline Tournefortia argentea & Widespread & Abundant \\
\hline Triumfetta procumbens & Limited & Abundant \\
\hline
\end{tabular}

${ }^{1}$ Recorded in Freeman (2006b) as last seen in 1938.

${ }^{2}$ Recorded as extinct by Freeman (2006b), but seen at Palmyra Atoll subsequent to these data.

${ }^{3}$ Recorded elsewhere by Freeman (2006b) as "may be extinct" (Suriana maritima may be locally extinct). 
Table 3. Collectors of vascular plants at Palmyra Atoll in chronological order.

[From Herbst (1992)]

\begin{tabular}{|c|c|}
\hline Name & Date of collections \\
\hline Thomas H. Streets & December $12-27,1873$ \\
\hline Joseph F.C. Rock & July12-28, 1913 \\
\hline Charles Montague Cooke, Jr. & July $12-28,1913$ \\
\hline Henry E. Cooper & July 12-28, 1913, March 1914 \\
\hline Edwin H. Bryan, Jr. & March 23, 1935, August11-12, 1938 \\
\hline Albert F. Judd & June 13,1935 \\
\hline Donald D. Mitchell & June 13, 1935 \\
\hline Ashley Brown & October 17, 1939 \\
\hline Margaret Hill & October 1949, December 1949 \\
\hline E. Yale Dawson & October $15-21,1958$ \\
\hline Henry S. Moeller & December 28, 1959-January 3, 1960 \\
\hline Charles Robert Long & June 6-7, 1964, November 27-28, 1964 \\
\hline Derral R. Herbst & September 18-25, 1987, February 24- March 3, 1992 \\
\hline
\end{tabular}


Table 4. Mammal species identified at Palmyra Atoll.

\begin{tabular}{|ll|}
\hline \multicolumn{1}{|c|}{ Family/species } & \multicolumn{1}{c|}{ Status } \\
\hline $\begin{array}{l}\text { Family Canidae (dogs) } \\
\text { Canis familiaris }\end{array}$ & nonnative \\
$\begin{array}{l}\text { Family Felidae (cats) } \\
\text { Felis catus }\end{array}$ & \\
Family Suidae (hogs, pigs) & nonnative \\
Sus domestica & \\
Family Muridae (mice, rats) & nonnative—no longer present \\
Rattus rattus & \\
\hline
\end{tabular}


Table 5. Avifauna of Palmyra Atoll.

[Modified from Fefer (1987) and adapted from R.B. Clapp (U.S. Geological Survey, written commun., 1966 in Fefer, 1987). Domestic chicken reported in Flint and others (1992); black tern reported by A. Wegmann, oral commun., University of Hawai i, 2008]

\begin{tabular}{|c|c|}
\hline Species & Status \\
\hline \multicolumn{2}{|l|}{ Sea birds } \\
\hline Audubon's shearwater (Puffinus lherminieri) & Rare visitant \\
\hline Black noddy (Anous minutus) & Abundant resident \\
\hline Black tern (Chlidonias niger) & Rare visitant \\
\hline Brown booby (Sula leucogaster) & Common resident \\
\hline Brown noddy (Anous stolidus) & Common resident \\
\hline Great crested tern (Sterna bergii) & Rare visitant \\
\hline Great frigatebird (Fregata minor) & Common resident \\
\hline Lesser frigatebird (Fregata ariel) & Rare visitant \\
\hline Masked booby (Sula dactylatra) & Uncommon resident \\
\hline Red-footed booby (Sula sula) & Abundant resident \\
\hline Red-tailed tropicbird (Phaethon rubricauda) & Uncommon resident \\
\hline Sooty tern (Sterna fuscata) & Abundant resident \\
\hline White tern (Gygis alba) & Common resident \\
\hline White-tailed tropicbird (Phaethon lepturus) & Uncommon resident \\
\hline \multicolumn{2}{|l|}{ Shore birds } \\
\hline Bristle-thighed curlew (Numenius tahitiensis) & Abundant migrant \\
\hline Lesser golden plover (Pluvialis dominica) & Abundant migrant \\
\hline Ruddy turnstone (Arenaria interpres) & Abundant migrant \\
\hline Sanderling (Calidris alba) & Uncommon migrant \\
\hline Sharp-tailed sandpiper (Calidris acuminata) & Uncommon migrant \\
\hline Wandering tattler (Heteroscelus incanus) & Abundant migrant \\
\hline \multicolumn{2}{|l|}{ Accidentals and introductions } \\
\hline American wigeon (Anas americana) & Accidental \\
\hline Cattle egret (Bubulcus ibis) & Accidental \\
\hline Crested mynah (Acridotheres cristatellus) & Introduction (extirpated) \\
\hline Domestic chicken (Gallus gallus) & Introduction (extirpated) \\
\hline Eurasian wigeon (Anas penelope) & Accidental \\
\hline Franklin's gull (Larus pipixcan) & Accidental \\
\hline Green-winged teal (Anas crecca) & Accidental \\
\hline Laughing gull (Larus atricilla) & Accidental \\
\hline Mallard (Anas platyrhynchos) & Accidental \\
\hline $\begin{array}{l}\text { Pintail (Anas acuta) } \\
\text { Shoveler (Anas clypeata) }\end{array}$ & $\begin{array}{l}\text { Accidental } \\
\text { Accidental }\end{array}$ \\
\hline
\end{tabular}


Table 6. Herpetofauna using the terrestrial habitat at Palmyra Atoll.

\begin{tabular}{|ll|}
\hline \multicolumn{1}{|c|}{ Family/species } & \multicolumn{1}{c|}{ Status } \\
\hline $\begin{array}{l}\text { Amphibians } \\
\text { Family Bufonidae (toads) } \\
\text { Bufo marinus }\end{array}$ & \\
\hline $\begin{array}{l}\text { Reptiles } \\
\text { Family Gekkonidae (geckos) } \\
\text { Lepidodactylus } \text { n. sp. } \\
\text { Lepidodactylus lugubris } \\
\text { Hemidactylus frenatus }\end{array}$ & \\
& \\
Turtles & nonnative last seen in 2002 \\
Family Cheloniidae (sea turtles) & possibly nonnative \\
Chelonia mydas & nonnative \\
Eretmochelys imbricata & \\
\hline
\end{tabular}


Table 7. Terrestrial native and nonnative arthropod species identified at Palmyra Atoll.

[Names of native species are in bold. Taxa: G. sp. indicates undetermined genus and species. The origin listed for each species was modified from Handler and others (2007)]

\begin{tabular}{|c|c|c|}
\hline Order/family & Taxa & Origin \\
\hline \multicolumn{3}{|l|}{ Order Araneae (spiders) } \\
\hline Agelenidae & Agelenidae G. sp. & Cryptogenic \\
\hline Araneidae & Neoscona theisi (Walckenaer, 1841) & Introduced \\
\hline Heteropodidae & Heteropoda venatoria (Linnaeus, 1767) & Introduced \\
\hline Pholcidae & Smeringopus pallidus (Blackwall, 1856) & Introduced \\
\hline \multirow[t]{8}{*}{ Salticidae } & Hasarius adansoni (Audouin, 1826) & Introduced \\
\hline & Menemerus bivittatus (Dufour, 1831) & Introduced \\
\hline & Messua cf. felix (Peckham \& Peckham, 1901) & Introduced \\
\hline & Phintella versicolor (C. L. Koch, 1846) & Cryptogenic \\
\hline & Plexippus paykulli (Audouin, 1826) & Introduced \\
\hline & Salticidae G. sp. 1 & Cryptogenic \\
\hline & Salticidae G. sp. 2 & Cryptogenic \\
\hline & Sandalodes sp. & Cryptogenic \\
\hline \multirow[t]{2}{*}{ Scytodidae } & Scytodes longipes (Lucas, 1845) & Introduced \\
\hline & Scytodes striatipes (L. Koch, 1872) & Introduced \\
\hline Tetragnathidae & Tetragnatha keyserlingi (Simon, 1890) & Native? \\
\hline \multirow[t]{3}{*}{ Theridiidae } & Coleosoma floridanum (Banks, 1900) & Introduced \\
\hline & Latrodectus geometricus (C. L. Koch, 1841) & Introduced \\
\hline & Nesticodes rufipes (Lucas, 1846) & Introduced \\
\hline \multicolumn{3}{|c|}{ Order Blattodea (cockroaches) } \\
\hline Blaberidae & Pycnoscelus indicus (Fabricius, 1775) & Introduced \\
\hline Blatellidae & Supella longipalpa (Fabricius, 1798) & Introduced \\
\hline \multirow[t]{3}{*}{ Blattidae } & Periplaneta americana (Linnaeus, 1758) & Introduced \\
\hline & Periplaneta australasiae (Fabricius, 1775) & Introduced \\
\hline & Platyzosteria soror (Brunner, 1865) & Introduced \\
\hline \multicolumn{3}{|l|}{ Order Coleoptera (beetles) } \\
\hline \multirow[t]{2}{*}{ Anthribidae } & Araecerus vieillardi (Montrouzier, 1860) & Introduced \\
\hline & Mauia subnotatus (Boheman, 1859) & Introduced \\
\hline Carabidae & Carabidae G. sp & Cryptogenic \\
\hline \multirow[t]{2}{*}{ Cerambycidae } & Cerambycidae G. sp. 1 & Cryptogenic \\
\hline & Cerambycidae G. sp. 2 & Cryptogenic \\
\hline \multirow[t]{2}{*}{ Coccinellidae } & Coccinellidae G. sp. & Cryptogenic \\
\hline & Coelophora inaequalis (Fabricius, 1775) & Introduced \\
\hline
\end{tabular}


Table 7. Terrestrial native and nonnative arthropod species identified at Palmyra Atoll._Continued

\begin{tabular}{|c|c|c|}
\hline Order/family & Taxa & Origin \\
\hline \multirow[t]{2}{*}{ Coccinellidae (continued) } & Diomus notescens (Blackburn, 1889) & Introduced \\
\hline & Rhyzobius lophanthae (Blaisdell, 1892) & Introduced \\
\hline Cryptophagidae & Toramus(?) sp. & Cryptogenic \\
\hline Cucujidae & Psammoecus insularis (Sharp, 1885) & Introduced \\
\hline \multirow[t]{2}{*}{ Elateridae } & Conoderus pallipes (Eschscholtz, 1829) & Introduced \\
\hline & Melanoxanthus melanocephalus (Fabricius, 1781) & Introduced \\
\hline Hydrophilidae & Dactylosternum abdominale (Fabricius, 1792) & Introduced \\
\hline Nitidulidae & Carpophilus humeralis (Fabricius, 1798) & Introduced \\
\hline \multirow[t]{5}{*}{ Oedemeridae } & Eobia bicolor (Fairmaine, 1849) & Introduced \\
\hline & Eobia decolor (Fairmaine, 1849) & Introduced \\
\hline & Eobia kanack (Fairmaine, 1849) & Introduced \\
\hline & Eobia sinensis (Gemminger, 1870) & Introduced \\
\hline & Sessinia livida (Fabricius, 1775) & Introduced \\
\hline Pselaphidae & Pselaphidae G. sp. & Cryptogenic \\
\hline Ptilidae & Ptilidae G. sp. & Cryptogenic \\
\hline Scarabaeidae & Saprosites pygmaeus (Harold, 1877) & Introduced \\
\hline Scolytidae & Xyleborus perforans (Wollaston, 1857) & Introduced \\
\hline Staphylinidae & Philonthus discoideus (Gravenhorst, 1802) & Introduced \\
\hline \multicolumn{3}{|l|}{ Order Dermaptera (earwigs) } \\
\hline Carcinophoridae & Euborellia annulipes (Lucas, 1847) & Introduced \\
\hline \multicolumn{3}{|l|}{ Order Diptera (true flies) } \\
\hline \multirow[t]{2}{*}{ Agromyzidae } & Liriomyza sativae (Blanchard, 1938) & Introduced \\
\hline & Liriomyza sp. & Cryptogenic \\
\hline \multirow[t]{2}{*}{ Calliphoridae } & Chrysomya megacephala (Fabricius, 1794) & Introduced \\
\hline & Lucilia sericata (Meigen, 1826) & Introduced \\
\hline \multirow[t]{2}{*}{ Canaceidae } & Canaceoides sp. & Cryptogenic \\
\hline & Nocticanace marshallensis (Wirth) & Native? \\
\hline \multirow[t]{2}{*}{ Ceratopogonidae } & Ceratopogonidae G. sp. & Cryptogenic \\
\hline & Dasyhelea sp. & Cryptogenic \\
\hline \multirow[t]{2}{*}{ Chironomidae } & Chironomidae G. sp. & Cryptogenic \\
\hline & Clunio sp. & Cryptogenic \\
\hline \multirow[t]{3}{*}{ Chloropidae } & Cadrema pallida (Loew, 1865) & Introduced \\
\hline & Gaurax bicoloripes (Malloch, 1933) & Introduced \\
\hline & Hippelates sp. & Cryptogenic \\
\hline \multirow[t]{2}{*}{ Culicidae } & Aedes albopictus (Skuse, 1894) & Introduced \\
\hline & Culex quinquefasciatus (Say, 1823) & Introduced \\
\hline
\end{tabular}


Table 7. Terrestrial native and nonnative arthropod species identified at Palmyra Atoll.-Continued

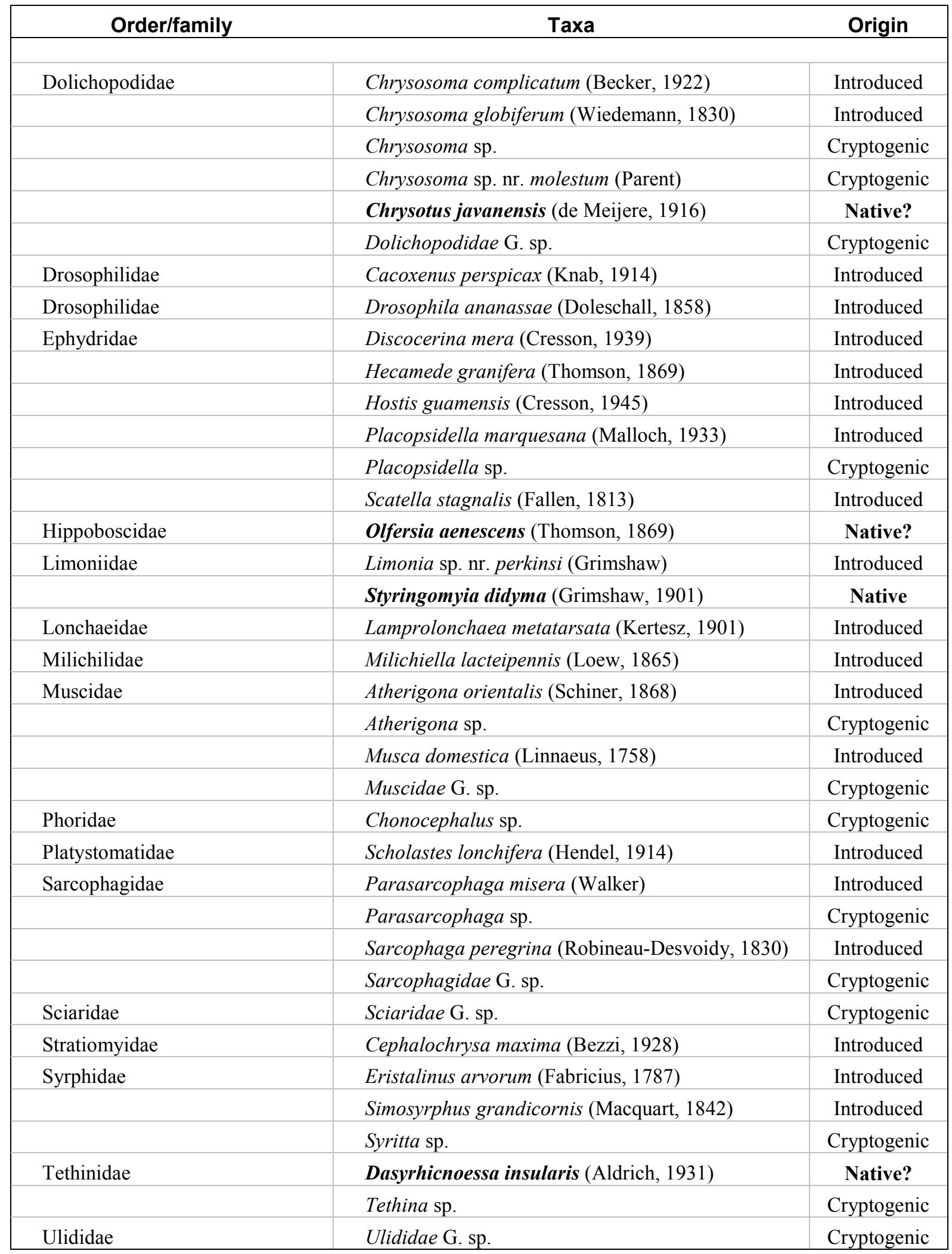


Table 7. Terrestrial native and nonnative arthropod species identified at Palmyra Atoll.-Continued

\begin{tabular}{|c|c|c|}
\hline Order/family & Taxa & Origin \\
\hline \multicolumn{3}{|c|}{ Order Hemiptera (Heteroptera) (true bugs) } \\
\hline Cynidae & Geotomus pygmaeus (Dallas, 1851) & Introduced \\
\hline Gerridae & Halobates micans (Eschscholz, 1822) & Native \\
\hline \multirow[t]{2}{*}{ Miridae } & Miridae G. sp. & Cryptogenic \\
\hline & Trigonotylus brevipes (Jakovlev, 1880) & Native? \\
\hline Reduviidae & Reduviidae G. sp. & Cryptogenic \\
\hline \multicolumn{3}{|c|}{ Order Hemiptera (Sternorrhyncha) (aphids, whiteflies, scale insects) } \\
\hline Aleyrodidae & Aleyrodidae G. sp. & Introduced \\
\hline Aphididae & Aphididae G. sp. & Cryptogenic \\
\hline Coccidae & Pulvinaria urbicola (Cockerell \& Parrott, 1899) & Introduced \\
\hline Margarodidae & Icerya purchasi (Maskell, 1879) & Introduced \\
\hline \multirow[t]{3}{*}{ Pseudococcidae } & $\begin{array}{l}\text { Dysmicoccus brevipes (Cockerell, 1893) } \\
\text { Dysmicoccus neobrevipes (Beardsley, 1959) }\end{array}$ & $\begin{array}{l}\text { Introduced } \\
\text { Introduced }\end{array}$ \\
\hline & Ferrisia virgata (Cockerell, 1893) & Introduced \\
\hline & Planococcus citri (Risso, 1813) & Introduced \\
\hline \multicolumn{3}{|c|}{ Order Hymenoptera (ants, bees, wasps) } \\
\hline \multirow[t]{2}{*}{ Aphelinidae } & Coccophagus ceroplastae (Howard, 1895) & Introduced \\
\hline & Euryischomyia flavithorax (Girault \& Dodd, 1915) & Introduced \\
\hline Cynipidae & Kleidotoma sp. & Cryptogenic \\
\hline Diapriidae & Trichopria sp. & Cryptogenic \\
\hline Encyrtidae & Metaphycus flavus (Howard, 1881) & Introduced \\
\hline \multirow[t]{2}{*}{ Eulophidae } & Aprostocetus hagenowii (Ratzeburg, 1852) & Introduced \\
\hline & Hemiptarsenus semialbiclavus (Girault, 1916) & Introduced \\
\hline Evaniidae & Evania appendigaster (Linnaeus, 1758) & Introduced \\
\hline \multirow[t]{10}{*}{ Formicidae } & Cardiocondyla emeryi (Forel, 1881) & Introduced \\
\hline & Cardiocondyla minutior (Forel) & Introduced \\
\hline & Hypoponera punctatissima (Roger, 1859) & Introduced \\
\hline & Monomorium floricola (Jerdon, 1851) & Introduced \\
\hline & Paratrechina bourbonica (Forel, 1886) & Introduced \\
\hline & Paratrechina longicornis (Latreille, 1802) & Introduced \\
\hline & Paratrechina vaga (Forel, 1901) & Introduced \\
\hline & Pheidole megacephala (Fabricius, 1793) & Introduced \\
\hline & Tapinoma melanocephalum (Fabricius, 1793) & Introduced \\
\hline & Tetramorium bicarinatum (Nylander, 1847) & Introduced \\
\hline \multirow[t]{2}{*}{ Megachilidae } & Megachile fullawayi (Cockerell, 1914) & Introduced \\
\hline & Megachile sp. & Cryptogenic \\
\hline
\end{tabular}


Table 7. Terrestrial native and nonnative arthropod species identified at Palmyra Atoll._Continued

\begin{tabular}{|c|c|c|}
\hline Order/family & Taxa & Origin \\
\hline Scelionidae & Scelionidae G. sp. & Cryptogenic \\
\hline \multirow[t]{2}{*}{ Sphecidae } & Sceliphron caementarium (Drury, 1770) & Introduced \\
\hline & Sphecidae G. sp. & Cryptogenic \\
\hline \multirow[t]{2}{*}{ Vespidae } & Pachodynerus nasidens (Latreille, 1802) & Introduced \\
\hline & Polistes aurifer (Saussure, 1853) & Introduced \\
\hline \multicolumn{3}{|l|}{ Order Isopoda (pillbugs) } \\
\hline Philosciidae & Australophiloscia societatis (Maccagno, 1932) & Native \\
\hline \multicolumn{3}{|l|}{$\begin{array}{l}\text { Order Lepidoptera (moths, } \\
\text { butterflies) }\end{array}$} \\
\hline Agonoxenidae & Agonoxena argaula (Meyrick, 1921) & Introduced \\
\hline Cosmopterigidae & Anatrachyntis incertulella (Walker, 1864) & Introduced \\
\hline Crambidae & Piletocera signiferalis (Wallengren) & Cryptogenic \\
\hline Gelechiidae & Stoeberhinus testaceus (Butler, 1881) & Introduced \\
\hline Gracillariidae & Gracillariidae G. sp. & Cryptogenic \\
\hline \multirow[t]{2}{*}{ Noctuidae } & Chrysodeixis eriosoma (Doubleday, 1843) & Introduced \\
\hline & Spodoptera litura (Fabricius, 1775) & Introduced \\
\hline Nymphalidae & Hypolimnas bolina (Linnaeus, 1758) & Native? \\
\hline Sphingidae & Agrius cingulata (Fabricius, 1775) & Introduced \\
\hline \multirow[t]{2}{*}{ Tineidae } & Erechthias simulans (Butler, 1882) & Introduced \\
\hline & Opogona sp. & Cryptogenic \\
\hline \multicolumn{3}{|c|}{ Order Odonata (dragonflies, damselflies) } \\
\hline Aeshnidae & Anax junius (Drury, 1770) & Native \\
\hline Coenagrionidae & Ischnura aurora (Brauer, 1865) & Native \\
\hline \multirow[t]{2}{*}{ Libellulidae } & Crocothemis servilea (Drury, 1770) & Introduced \\
\hline & Pantala flavescens (Fabricius, 1770) & Native \\
\hline \multicolumn{3}{|c|}{ Order Orthoptera (grasshoppers, crickets, katydids) } \\
\hline Acrididae & Oxya japonica (Thunberg, 1824) & Introduced \\
\hline \multirow[t]{4}{*}{ Gryllidae } & Cycloptilum sp. & Cryptogenic \\
\hline & Ornebius sp. & Cryptogenic \\
\hline & Speonemobius tigrinus (Saussure) & Native? \\
\hline & Teleogryllus oceanicus (Le Guillou, 1841) & Introduced \\
\hline Pyrgomorphidae & Atractomorpha sinensis (Bolivar, 1905) & Introduced \\
\hline \multirow[t]{2}{*}{ Tettigoniidae } & Conocephalus saltator (Saussure, 1859) & Introduced \\
\hline & Phisis holdhausi (Karny, 1926) & Native \\
\hline
\end{tabular}


Table 8. Terrestrial crabs of Palmyra Atoll.

\begin{tabular}{|c|c|}
\hline Family/species & Status \\
\hline \multicolumn{2}{|l|}{ Family Coenobitidae (land hermit crabs) } \\
\hline Birgus latro & native \\
\hline Coenobita perlatus & native \\
\hline Coenobita brevimanus & native \\
\hline \multicolumn{2}{|l|}{ Family Gecarcinidae (land crabs) } \\
\hline Cardisoma carnifex & native \\
\hline Cardisoma rotundum & native \\
\hline \multicolumn{2}{|l|}{ Family Grapsidae (marsh, shore, and talon crabs) } \\
\hline Geograpsus crinipes & native \\
\hline
\end{tabular}


Table 9. Palmyra Atoll resources of concern.

[Question mark (?) indicates key uncertainty regarding the impact of the limiting factor and requires further investigation. "State" is an approximation of the deviation from recent or historical surveys, trips, and studies of Palmyra Atoll on a scale of Low - Moderate - High. "Target" descriptions often imply that we know current age structure and population status. Beach nesters are included in this plan because of proximity to terrestrial forest and thus possible direct impact from forest management.]

\begin{tabular}{|c|c|c|c|c|}
\hline Resource & Species & Current "State" & Limiting Factors & Target \\
\hline \multicolumn{5}{|c|}{ Plants } \\
\hline $\begin{array}{l}\text { Pisonia grandis } \\
\text { forest }\end{array}$ & $\begin{array}{l}\text { Pisonia grandis forest } \\
\text { native species } \\
\text { constituents }\end{array}$ & Moderate - High & $\begin{array}{l}\text { - Coconut palm } \\
\text { competition } \\
\text { - Phymatosorus } \\
\text { scolopendria } \\
\text { competition? } \\
\text { - Altered substrates? } \\
\text { - Contaminants? } \\
\text { - Altered } \\
\text { groundwater levels? } \\
\text { - Storm events by } \\
\text { direct damage to trees } \\
\text { - Storm events } \\
\text { increasing } \\
\text { groundwater salinity? } \\
\text { - Low abundance of } \\
\text { ectomycorrhizae? } \\
\text { - Altered nutrient } \\
\text { cycling/availability }\end{array}$ & $\begin{array}{l}\text { - Retain to the extent } \\
\text { possible existing large } \\
\text { and mid-sized trees } \\
\text { - Increase proportion } \\
\text { of small trees } \\
\text { - Ensure that Pisonia } \\
\text { grandis recolonizes } \\
\text { canopy gaps } \\
\text { - Increase Pisonia } \\
\text { grandis in 50-m buffer } \\
\text { around existing stands }\end{array}$ \\
\hline $\begin{array}{l}\text { Coastal strand } \\
\text { forest }\end{array}$ & $\begin{array}{l}\text { Coastal strand native } \\
\text { species constituents }\end{array}$ & Low & $\begin{array}{l}\text { - Coconut palm } \\
\text { competition } \\
\text { - Erosion } \\
\text { - Contaminants? } \\
\text { - Storm events by } \\
\text { direct damage to trees }\end{array}$ & - Continuous canopy \\
\hline Grassland & $\begin{array}{l}\text { Grassland native } \\
\text { species constituents in } \\
\text { particular Lepturus } \\
\text { repens var. } \\
\text { palmyrensis }\end{array}$ & Moderate - High & $\begin{array}{l}\text { - Forest succession? } \\
\text { - Coconut palm } \\
\text { competition? } \\
\text { - Altered substrates } \\
\end{array}$ & $\begin{array}{l}\text { - Maintain at levels } \\
\text { documented by } \\
\text { Freeman (2006a) }\end{array}$ \\
\hline
\end{tabular}


Table 9. Palmyra Atoll resources of concern. - Continued

\begin{tabular}{|c|c|c|c|c|}
\hline Resource & Species & Current "State" & Limiting Factors & Target \\
\hline \multicolumn{5}{|c|}{ Animals } \\
\hline Ground nesters & $\begin{array}{l}\text { Brown booby } \\
\text { Masked bobby } \\
\text { Red-tailed tropic- } \\
\text { bird } \\
\text { Sooty tern }\end{array}$ & Low & $\begin{array}{l}\text { - Rat predation } \\
\text { - Lowered pelagic } \\
\text { forage } \\
\text { - Reduced nesting } \\
\text { substrate }\end{array}$ & $\begin{array}{l}\text { - Increase production } \\
\text { - Increase population } \\
\text { size }\end{array}$ \\
\hline $\begin{array}{l}\text { Burrowing } \\
\text { nesters }\end{array}$ & $\begin{array}{l}\text { Shearwaters } \\
\text { Petrels }\end{array}$ & Extirpated? & $\begin{array}{ll}\text { - } & \text { Rat predation } \\
\text { - } & \text { Pelagic forage } \\
\text { - } & \text { Nesting substrate }\end{array}$ & $\begin{array}{l}\text { - Natural self- } \\
\text { sustaining population }\end{array}$ \\
\hline Tree nesters & $\begin{array}{l}\text { Red-footed booby } \\
\text { Noddies }\end{array}$ & Low & $\begin{array}{l}\text { - Lowered pelagic } \\
\text { forage } \\
\text { - Reduced Pisonia } \\
\text { grandis and tree } \\
\text { heliotrope availability }\end{array}$ & $\begin{array}{l}\text { - Increase population } \\
\text { size }\end{array}$ \\
\hline $\begin{array}{l}\text { Shore and } \\
\text { intertidal flats } \\
\text { and forest } \\
\text { interior }\end{array}$ & $\begin{array}{l}\text { Bristle-thighed } \\
\text { curlew }\end{array}$ & $\begin{array}{l}\text { Present but no } \\
\text { best judgment of } \\
\text { state at this time }\end{array}$ & $\begin{array}{l}\text { - Contaminants? } \\
\text { - Rat predation }\end{array}$ & $\begin{array}{l}\text { - Decrease fall } \\
\text { mortality } \\
\text { - Increase Alaska } \\
\text { breeding density and } \\
\text { (or) fecundity }\end{array}$ \\
\hline Forest floor & Coconut crab & Moderate & $\begin{array}{l}\text { - Dense understory } \\
\text { (A. Wegmann, } \\
\text { University of Hawai i, } \\
\text { oral commun., 2008) } \\
\text { - Rat predation } \\
\text { - Habitat alteration by } \\
\text { coconut palm? }\end{array}$ & $\begin{array}{l}\text { - Increase production } \\
\text { - Increase distribution } \\
\text { within Palmyra Atoll } \\
\text { - Increase population } \\
\text { size }\end{array}$ \\
\hline Forest & Lizards & Low & $\begin{array}{l}\text { - } \quad \text { Rat predation } \\
\text { - } \quad \text { Nonnative geckos } \\
\text { (competition, parasites) }\end{array}$ & $\begin{array}{l}\text { - Increase population } \\
\text { size } \\
\text { - Increase distribution }\end{array}$ \\
\hline Forest & Insects & $\begin{array}{l}\text { Present but no } \\
\text { best judgment of } \\
\text { state at this time }\end{array}$ & $\begin{array}{l}\text { - Lack of inventory } \\
\text { information }\end{array}$ & $\begin{array}{l}\text { - Self-sustaining } \\
\text { populations of native } \\
\text { insects }\end{array}$ \\
\hline Beach nesters & Sea turtles & $\begin{array}{l}\text { Present at } \\
\text { Palmyra Atoll } \\
\text { National } \\
\text { Wildlife Refuge } \\
\text { no current } \\
\text { evidence of } \\
\text { nesting }\end{array}$ & $\begin{array}{l}\text { - Rat predation (eggs } \\
\text { and hatchlings) } \\
\text { - Islet configuration } \\
\text { - Lagoon hydrology }\end{array}$ & $\begin{array}{l}\quad \text { Natural self- } \\
\text { sustaining population? }\end{array}$ \\
\hline
\end{tabular}


Table 10. Experts consulted regarding Palmyra Atoll management planning.

\begin{tabular}{|c|c|}
\hline Name & Affiliation \\
\hline Lisa Balance & $\begin{array}{l}\text { National Oceanic and Atmospheric Administration } \\
\text { Southwest Fisheries, La Jolla, California }\end{array}$ \\
\hline Steve Barclay & $\begin{array}{l}\text { U.S. Fish and Wildlife Service } \\
\text { Pacific/Remote Islands National Wildlife Refuge Complex, Honolulu, Hawaìi }\end{array}$ \\
\hline Pat Biley & The Nature Conservancy, Maui Program, Honolulu, Hawai`i \\
\hline John Collen & $\begin{array}{l}\text { Centre for Marine Environmental and Economic Research, Victoria University of } \\
\text { Wellington }\end{array}$ \\
\hline Chris Depkin & $\begin{array}{l}\text { U.S. Fish and Wildlife Service } \\
\text { Pacific/Remote Islands National Wildlife Refuge Complex, Honolulu, Hawaìi }\end{array}$ \\
\hline Donald Drake & University of Hawai`i, Honolulu, Hawai`i \\
\hline Elizabeth Flint & $\begin{array}{l}\text { U.S. Fish and Wildlife Service } \\
\text { Pacific/Remote Islands National Wildlife Refuge Complex, Honolulu, Hawaìi }\end{array}$ \\
\hline Kristen Hart & $\begin{array}{l}\text { U.S. Geological Survey } \\
\text { Florida Integrated Science Center, Fort Lauderdale, Florida }\end{array}$ \\
\hline Justin Kulongoski & $\begin{array}{l}\text { U.S. Geological Survey } \\
\text { California Water Science Center, San Diego, California }\end{array}$ \\
\hline Matthew McKown & University of North Carolina, Chapel Hill, North Carolina \\
\hline Barrie Morgan & The Nature Conservancy, Palmyra Program, Honolulu, Hawai`i \\
\hline Diana Papoulias & $\begin{array}{l}\text { U.S. Geological Survey } \\
\text { Columbia Environmental Research Center, Columbia, Missouri }\end{array}$ \\
\hline Robert Pitman & $\begin{array}{l}\text { National Oceanic and Atmospheric Administration } \\
\text { Southwest Fisheries, La Jolla, California }\end{array}$ \\
\hline Joanna Smith & University of Washington, Seattle, Washington \\
\hline William Smith & $\begin{array}{l}\text { U.S. Fish and Wildlife Service } \\
\text { Pacific/Remote Islands National Wildlife Refuge Complex, Honolulu, Hawaìi }\end{array}$ \\
\hline Eleanor Sterling & $\begin{array}{l}\text { American Museum of Natural History } \\
\text { New York, New York }\end{array}$ \\
\hline Alex Wegmann & University of Hawai $i$, Honolulu, Hawai' i, and Island Conservation \\
\hline Lee Ann Woodward & $\begin{array}{l}\text { U.S. Fish and Wildlife Service } \\
\text { Pacific/Remote Islands National Wildlife Refuge Complex, Honolulu, Hawaìi }\end{array}$ \\
\hline Hillary Young & Stanford University, Stanford, California \\
\hline
\end{tabular}




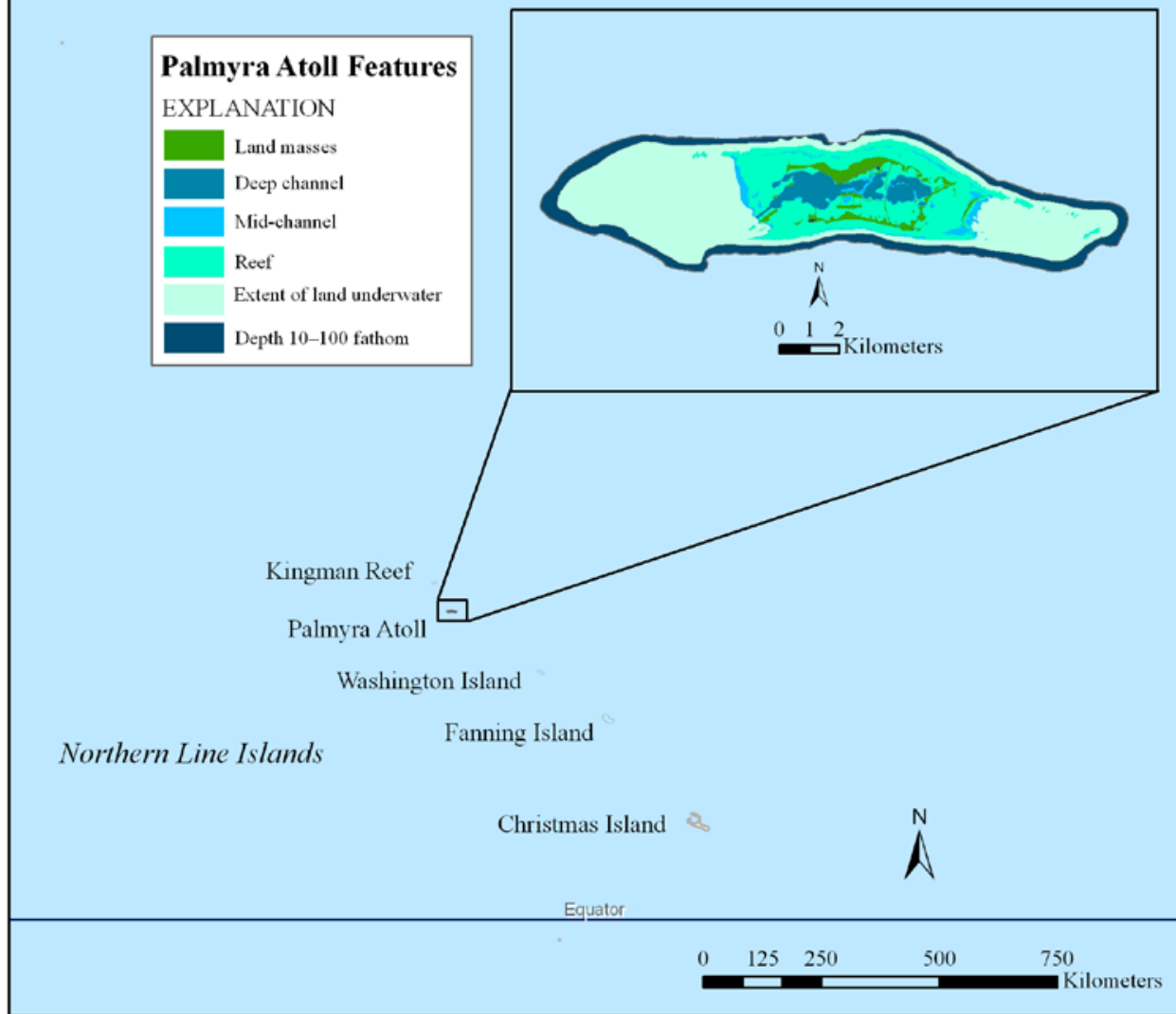

Figure 1. Map of Palmyra Atoll. 


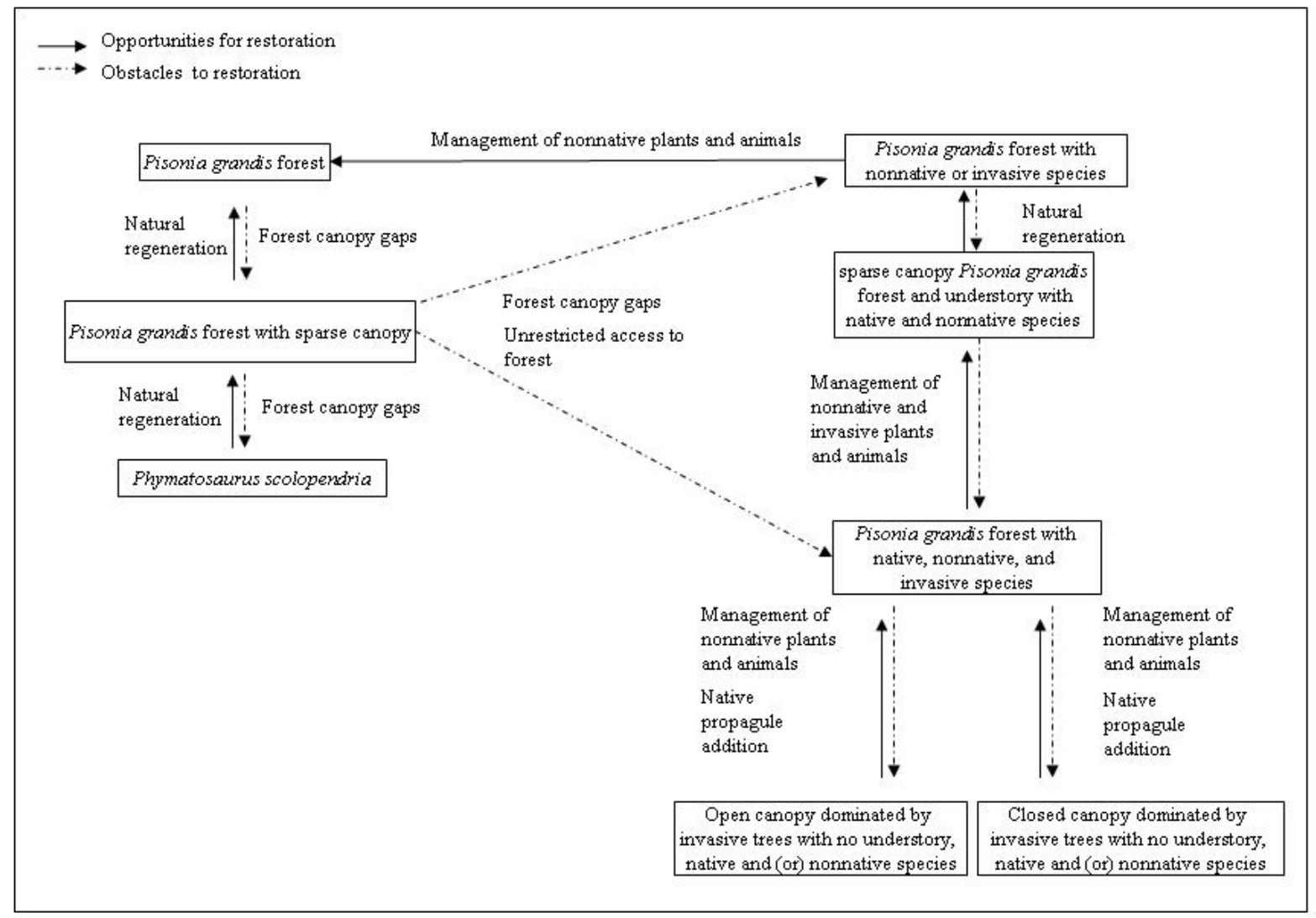

Figure 2. State-transition model for restoration of Pisonia grandis forest within Palmyra Atoll. Lines and arrows indicate transitions between states (dotted lines indicate obstacles to restoration, and solid lines indicate opportunities for restoration). 


\section{Appendix: Phase 1 Workplan}

\section{Coconut Palm Control Plan}

Applies to "Terrestrial Forest Management Plan for Palmyra Atoll":

Habitat Goal (HG1): Protect, maintain, and where possible restore terrestrial ecosystem integrity-the natural biological communities and their associated biodiversity, habitats, populations, ecological processes, and environmental health of Palmyra Atoll.

Applies to multiple Objectives in "Terrestrial Forest Management Plan for Palmyra Atoll":

- (HG1-O6) Maintain existing Pisonia grandis stands and promote new growth and expansion.

- (HG1-O6a) Maintain large trees in Pisonia grandis stands that incurred extensive large-tree mortality during the scale infestation.

- (HG1-O6b) Maintain regeneration of small trees in Pisonia grandis stands that incurred moderate mortality during the scale infestation.

- (HG1-O6c) Implement a "no net loss" Pisonia grandis strategy.

- (HG1-O7) Control coconut palm (Cocos nucifera) succession and incursion into Pisonia grandis stands that have suffered moderate to extensive mortality during the scale infestation.

- (HG1- O8) Create openings for native coastal shrubs to colonize monotypic coconut palm stands.

- (HG1-O13) Accelerate native forest restoration.

\section{Background}

The U.S. Fish and Wildlife Service (FWS) has a proposed invasive plant species removal plan intended to be implemented in 2010. While the plan is being evaluated and prioritized, it has been suggested that the invasive removal team dedicate some effort toward work on various parts of Palmyra Atoll. Suggested activities include the removal of Casuarina, Araucaria, and other similar nonnative or invasive species from Cooper Islet. There may also be some effort directed toward the removal of new invasive plants appearing on various islets, such as Pluchea on Cooper Islet. As yet, the FWS priorities are unclear regarding implementation of the invasive species removal plan. The discussion below is based on the assumption that the plan will move forward and address the invasive plant issues identified by the FWS.

Coconut palm has been shown to deplete nutrients from the terrestrial ecosystem by reducing habitat for sea bird roosting and nesting, which in turn reduces nutrient input that sea birds bring in from the marine environment (Young and others, 2010). Recent studies also suggest that the eradication of rats at Palmyra Atoll will significantly reduce seed and seedling predation pressure on coconut palms (A. Wegmann, University of Hawai i, written commun., 2008). Therefore, the U.S. Geological Survey (USGS) discussed with the FWS and others the possibility of incorporating coconut palm management and experimental cuts into the initial invasive plant management effort. While this would clearly be time and resource dependent, we include here several prioritized suggestions for coconut palm management actions consistent with current research and management objectives. This coconut palm control plan also assumes the development of a monitoring plan relevant to these actions prior to implementation. While adequate resources may not be available through current funding, the priorities below are important for the overall conservation and restoration of terrestrial forest ecosystem integrity and should be considered for future action. 


\section{Proposed Actions and Methods \\ Priority 1}

We suggest direct management action to remove coconut palms completely from Leslie, Dudley, and (or) Sand Islets. Coconut palm removal from Sand Islet, while perhaps the most desirable, would also be the most time intensive. We suggest Leslie Islet as a first option (as there are lower densities of nesting birds at this site) and Dudley Islet as an alternative option (fig. 1-1). Ainsley Islet could also be added on if time permits.

\section{Methods}

- Potential impacts of concern include damaging neighboring native plant species and nearby animals (for example, bird nesting, crabs directly and by burrow collapse). To minimize these problems, we suggest using a chemical method to kill the mature coconut palms (Sandoval and others, 2008) after evaluation that potential release of phytotoxins will not harm nontarget species.

- To prevent immediate regeneration by coconut palms it would be necessary to remove all nuts on the ground. Ideally, there would also be periodic work to destroy or remove nuts falling because of treatment, as well as new nuts washing up on the beaches. Any coconut palms found alive 1 year after treatment should be re-treated or mechanically destroyed.

- We suggest leaving all non-nut plant matter to decay on the ground naturally after the treatment activities.

\section{Monitoring Suggestions}

We suggest monitoring treated sites immediately before (if mechanical methods are used) and after the treatment by using long-term monitoring protocols. Such monitoring should be repeated at 1-, 2-, and 5-year intervals and at 5-year intervals thereafter.

\section{$\underline{\text { Priority } 2}$}

We recommend removing coconut palms from areas where this action has the potential to facilitate erosion of dredge fill creating gaps between original islets. This activity could be accomplished through poisoning (or mechanical removal if not in proximity to native forests). Three target areas include the narrow connecting bridges between Pelican and Holei Islets, between Holei and Engineer Islets, and between Kaula and Paradise Islets (fig.1-1). This adaptive management action should be done in coordination with geomorphology scientists and be consistent with reef flat and lagoon monitoring plan objectives, as well as related siting of focal stations (see "Draft Initial Monitoring Plan" [Lafferty and Kushner 2008]) and considered with any lagoon restoration planning respectively.

\section{Priority 3}

Given the long-term interest in large-scale coconut palm removal at Palmyra Atoll and concerns about what type of regeneration will result from such a removal, we suggest at least two large experimental cuts (at least 20 by $50 \mathrm{~m}$ in size). We suggest that one of these cuts be made on the edge of coconut palm/native forest and one be made in full coconut palm forest. Since research suggests that there is limited or no native propagule bank or native seed rain into coconut palm forest, we believe that underplanting would be necessary to facilitate native species succession at these sites. Without any underplanting, the cut sites will likely succeed quickly to more coconut palms or Phymatosorus scolopendria. The simplest species to use for underplantings would be tree heliotrope (Tournefortia argentea), as seedlings are readily available (North Beach and Whippoorwill Islet lagoon sides), can succeed both inland and on the coast in high light situations, and are not susceptible to herbivory. 
Pisonia grandis cuttings are also good candidates for underplanting. While seedlings of some species (for example, Pisonia grandis, Neisosperma oppositifolia) are desirable, they require advance germination and caging once transplanted. When conducting these experiments and applications after rat eradication, advance germination is not necessary; however, caging is still suggested because of the likelihood that crabs may move propagules, making them difficult to monitor, and they may kill seedlings.

\section{Methods}

We suggest chemical methods for the removal of coconut palms very proximal to Pisonia grandis or other uncommon native species and mechanical methods for areas of coconut palm only. In areas where chemical methods are possible, planting native species could begin before the trees have died. The slow dying process will result in gradually increasing light availability for seedlings that will "harden" them in the process, and they will thrive in direct sunlight (A. Wegmann, University of Hawai i, written commun., 2010); however, this may result in some mortality if not protected because of damage from falling nuts and fronds as coconut palms die.

- Site suggestions:

- Coconut palm only sites - A top priority would be to target Fern Islet (fig. 1-1) entirely and include native plantings with fencing or caging. If this is deemed undesirable for esthetic or other reasons, either Strawn or Kaula Islets would be possible alternative sites.

- Native only sites - Papala and Pelican Islets (fig. 1-1) have good boundary sites between coconut palms and native forests and would be top priority. Strawn Islet is also an option. It has a coconut palm stand near the Pisonia grandis grove, but removal here might be more visible to the public. A last option is Holei Islet. The major drawback to this site is the ongoing research in multiple locations on the islet and the difficulty in avoiding research sites, which could be seriously compromised.

\section{Monitoring Suggestions}

We suggest monitoring all sites immediately after the cutting activities and underplanting as a restoration research project by using detailed permanent marking and measuring protocols. Such monitoring should be repeated at 1-, 2-, and 5-year intervals and at 5-year intervals thereafter.

\section{$\underline{\text { Priority } 4}$}

Removing coconut palms from Pisonia grandis gap areas is another target activity. We recommend that this removal be done chemically.

\section{Staff}

Using the chemical methods described (see Sandoval and others, 2008) on Leslie Island extrapolated on the basis of area, initial nut removal will likely take at least as much time as chemical treatment, then it can be decreased to periodic 1 time per month checks or 1 time per quarter checks. It is unknown whether mechanical methods are comparable in labor requirements. Monitoring should take about one-half day per site, depending on site location, complexity, and number of plots. 
Priority 3 could include various options, but as an assumption of transplanting tree heliotrope seedlings, a site would probably take 1 day to harvest and plant depending on plant availability and site location.

Some uncertainties include determining optimal planting density, site preparation, moving debris from coconut palm falls, returning to water seedlings, and so on.

\section{Timing}

Initiate coconut palm removal as soon as possible. Avoid activities, particularly mechanical treatment of coconut palms, near nesting bird locations between $10 \mathrm{a} . \mathrm{m}$. and 2 p.m. (during the heat of the day).

\section{Equipment}

Equipment is variable depending on treatment method (chemical: drill, herbicide; mechanical: machete and (or) chainsaw) and restoration strategy (for example, if fencing or caging).

\section{Support}

Travel, supplies, accommodations (room and board), and so on

\section{Cost}

To be determined on the basis of whether the work would be done by staff, contractors, or volunteers.

\section{Logistical Questions}

Will flights to and from Palmyra Atoll and Honolulu, Hawai i be available as necessary to complete proposed actions?

\section{References Cited}

Lafferty, K.D., and Kushner, David, 2008, Draft initial monitoring plan for Palmyra Atoll: Sacramento, Calif., U.S. Geological Survey, Western Ecological Research Center, 74 p.

Sandoval, Cristina, Biley, Pat, Lafferty, Kevin, Hathaway, Stacie, and Smith, William, 2008, Evaluation of herbicide application to coconut trees on Palmyra Atoll (Oct 2007 to July 2008). Draft Trip Report: Honolulu, Hawai i, U.S. Fish and Wildlife Service, 3 p.

Young, H.S., McCauley, D.J., Dunbar, R.B., and Dirzo, Rodolfo, 2010, Plants cause ecosystem nutrient depletion via the interruption of bird-derived spatial subsidies: Proceedings of the National Academy of Sciences, v. 107, no. 5, p. 2072-2077. 


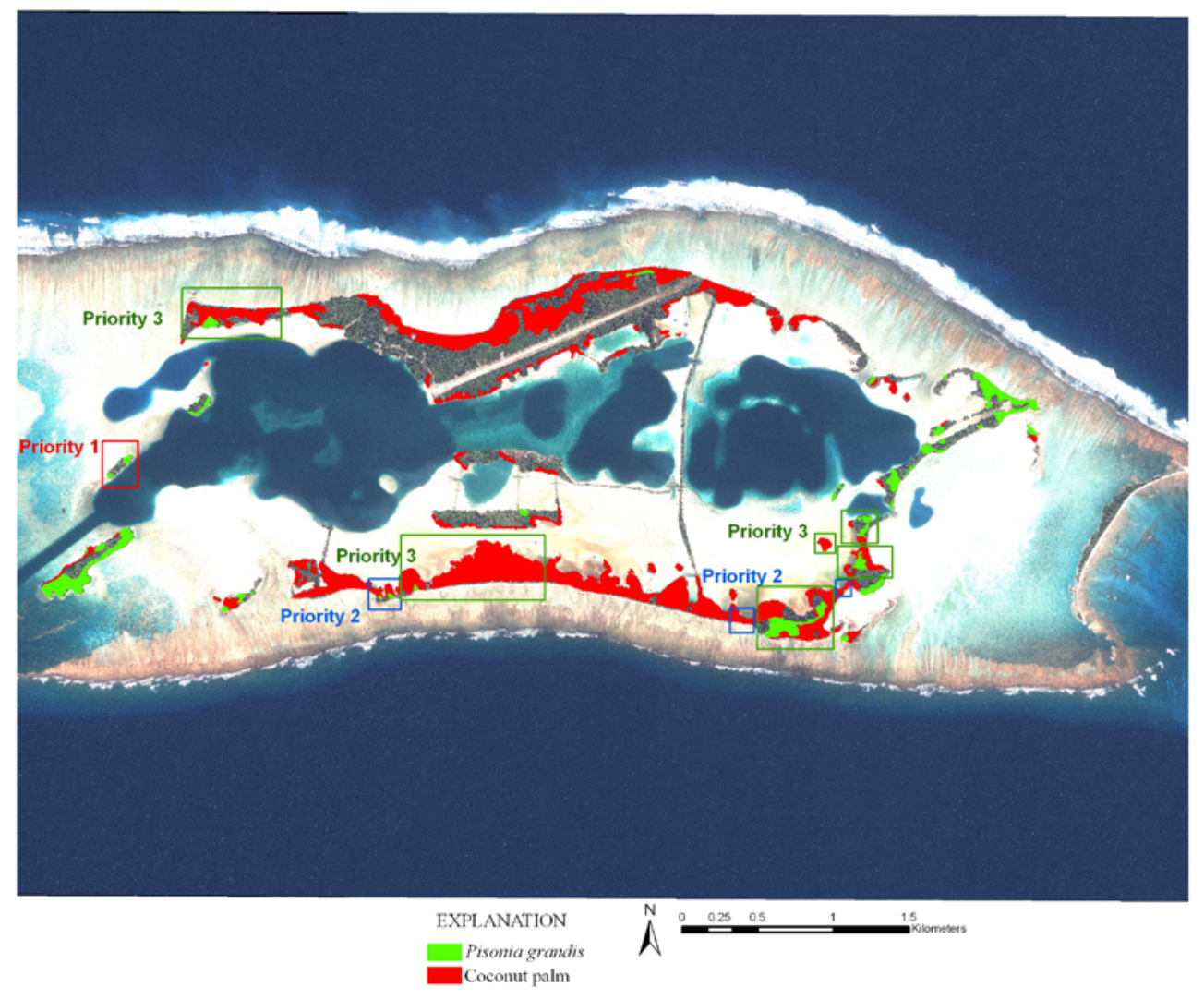

Figure 1-1. Priority areas for coconut palm removal at Palmyra Atoll. 
Publishing support provided by the U.S. Geological Survey

Publishing Network, Sacramento and Tacoma Publishing Service Centers

For more information concerning the research in this report, contact the Director, Western Ecological Research Center 3020 State University Drive East

Modoc Hall, Room 3006

Sacramento, CA 95819

http://www.werc.usgs.gov/ 


\section{总}

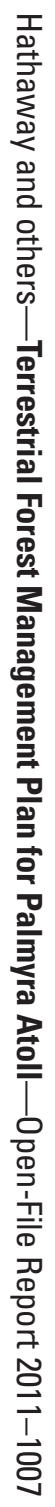

